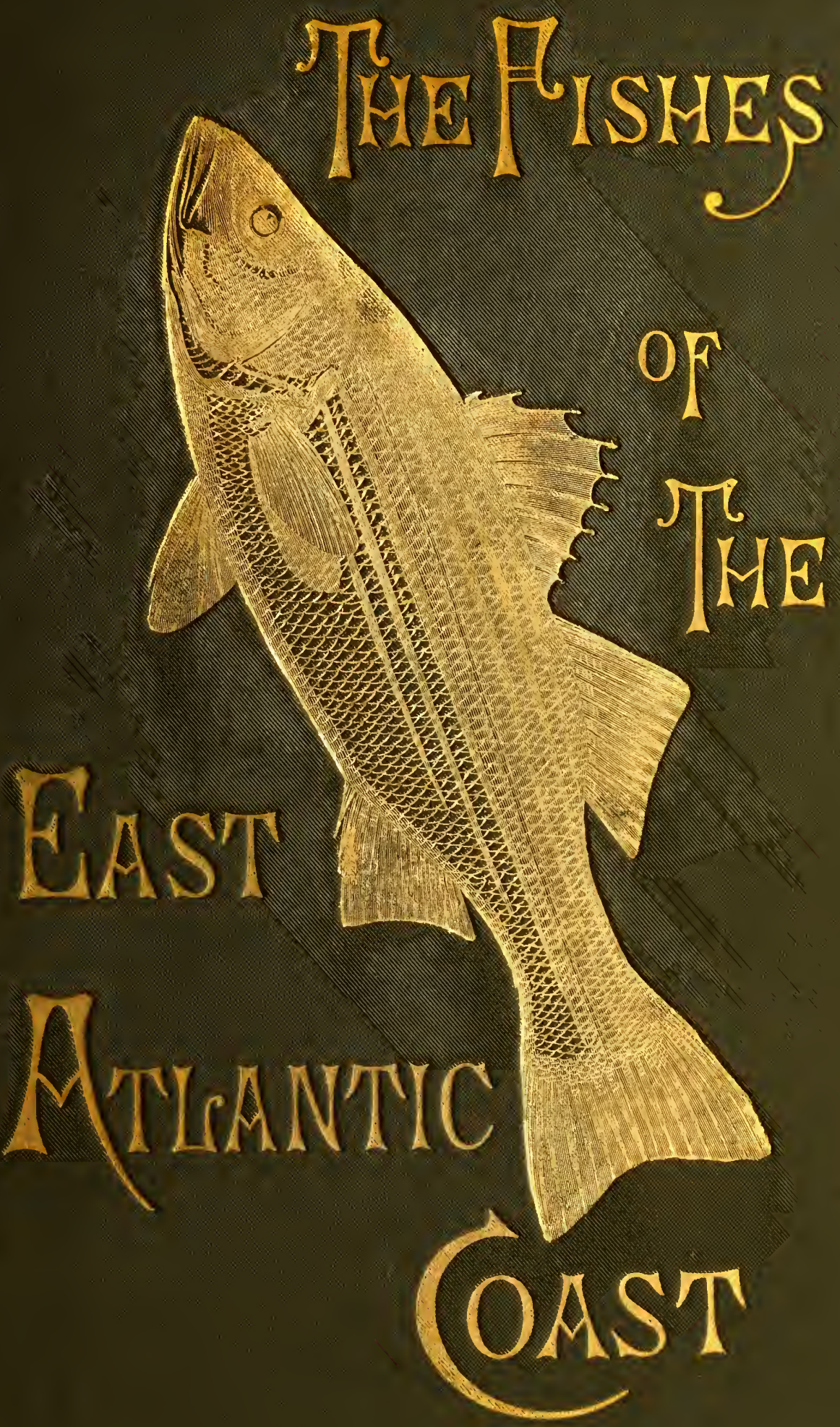




\section{HARVARD UNIVERSITY.}

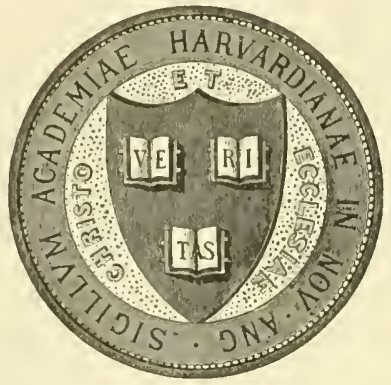

L I B R A R Y

OF THE

MUSEUM OF COMPARATIVE ZOÖLOGY

72,239

LIBRARY OF

SAMUEL GARMAN

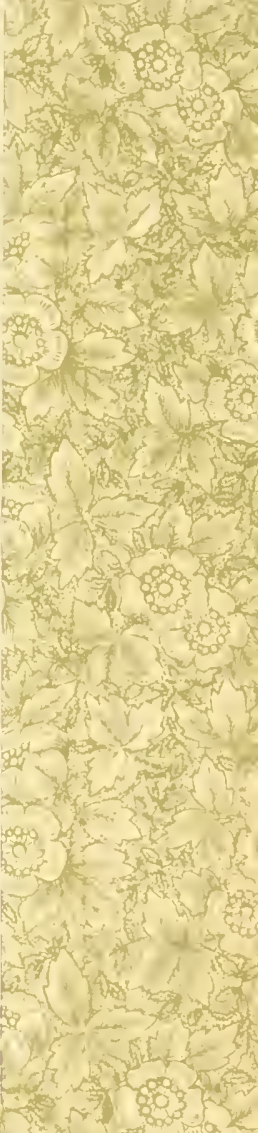



4 





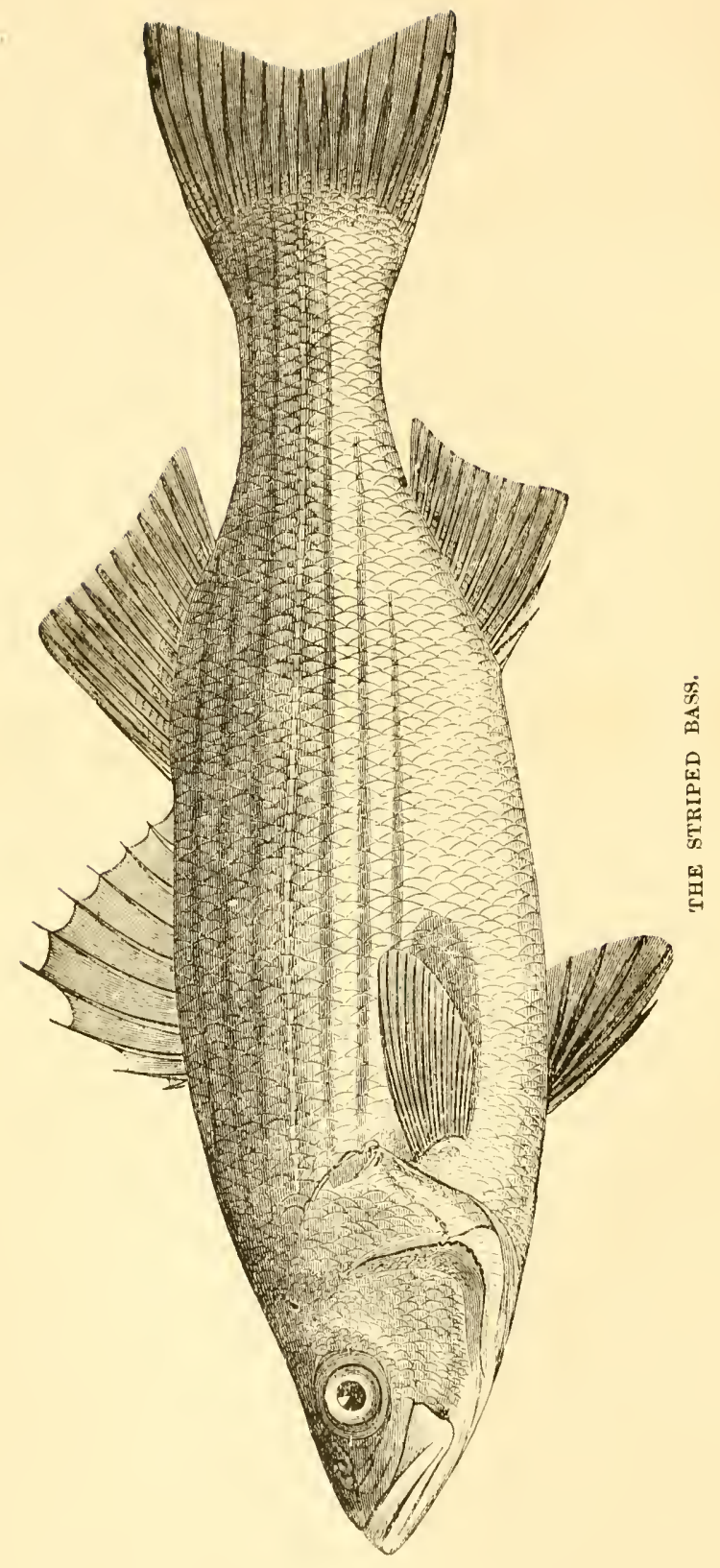




\title{
THE FISHES OF
}

\section{The East Atlantic Coast,}

THAT ARE

\section{CAUGHT WITH HOOK AND LINE,}

\author{
BY LOUIS O. VAN DOREN.
}

INCLUDING

The Fishes of the East Coast - $\mathrm{OF}-$

\author{
FLORIDA. \\ By SAMUEL C. CLARKE.
}

ILLUSTRATED.

NEW YORK:

Thf American Angler.

1884. 
Entered, according to act of Congress, in the year 1884, by WILLIAM C. HARRIS,

In the Office of the Librarian of Congress at Washington. 


\section{PUBLISHER'S ANNOUNCEMENT.}

Tre within pages contain the illustrated papers of Mr. Louis O. Van Doren, Mr. Samuel C. Clarke, and Dr. C. J. Kenworthy, "Al Fresco," that have appeared from time to time in the columns of The American Angler. They treat of all the fishes of the Atlantic Coast that are of interest to the rod and line fisherman, and in connection with the profuse illustrations form the most practical and comprehensive treatise on our salt water fishes, that has been published. 


\section{CONTENTS.}

CHAPTER I.

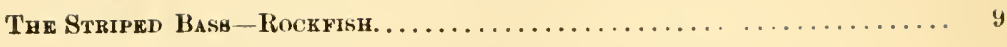

CHAPTER II.

The Bluefish.

CHAPTER III.

The Weakfish-Squeteauge. .

CHAPTER IV.

The Sheepshead

CHAPTFR V.

Tue Kingfish. 32

CHAPTER VI.

The Bonito. 36

CHAPTER VII.

The Blace Drum 40

CHAPTER VIII.

The Spanish Mackerel. 45

CHAPTER IX.

Thв Blackfinh 49

CHAPTER X.

The Flounder 54

CHAPTER XI.

The Sea Bass. 59

CHAPTER XII.

The Bergall 63

CHAPTER XIII.

The Tomcod.

CHAPTER XIV.

Trie Codfrsh

CHAP'TER XV.

The Haddock. 75 
CHAPTER XVI.

The Menhaden

CHAPTER XVII.

The Lafayette or Spot.

CHAPTER XVIII.

The Snapping Mackerel

CHAPTER XIX.

The SHAD

CHAP'TER XX.

The Crab and The Lobster

THE FISHES OF THE EAST FLORIDA COAST.

CHAPTER I.

The Species of Fishes found on the East Florida Coast.

CHAPTER II.

The Channel Bass

CHAPTEIR III.

The Salt Water Trout-Southern Weakfish

CHAPTER IV.

The Red Grouper

CHAPTER V.

The Rock Grouper.

The Pompano.

CHAPTER VI.

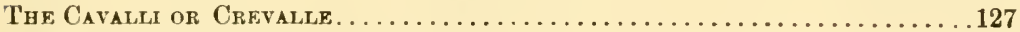

The Mangrove Snapper. . . . . . . . . . . . . . . . . . . . . . . 128

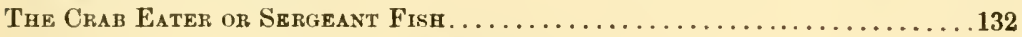

CHAPTER VII.

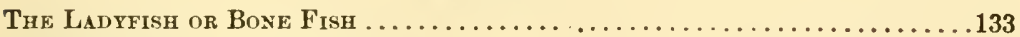

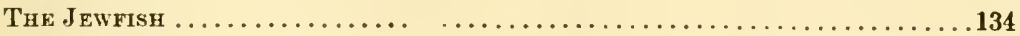

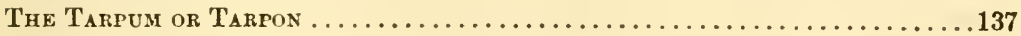

CHAPTER VIII.

The Drum . . . . . . . . . . . . . . . . . . . . . . . . . . . . . . 141

The Hogfish-Pigfish. . . . . . . . . . . . . . . . . . . . . . . . . . 142

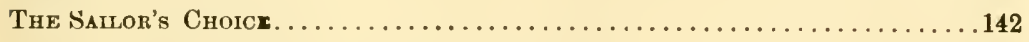

CHAPTER IX.

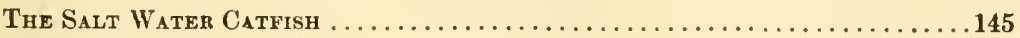

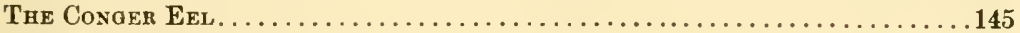

The Mullet . . . . . . . . . . . . . . . . . . . . . . . . . . . . 146

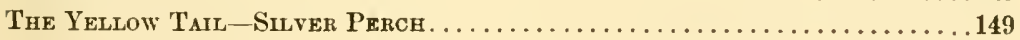


viii

CHAPTER $\mathrm{X}$.

The Sharks . . . . . . . . . . . . . . . . . . . . . . . . . . . . . 153

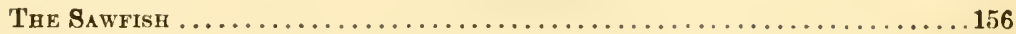

CHAP'TER XI.

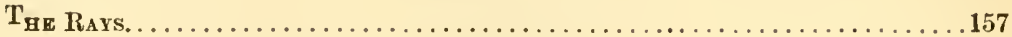

CHAPTER XII.

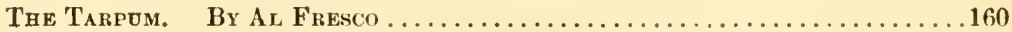

CHAPTER XIII.

THE FISHING GROUNDS OF FLOHIDA.

Tackle and Lures. By Dr. C. J. Kenworthy - Al Firesco . . . . . . . . . 171

\section{ILLUSTRATIONS.}

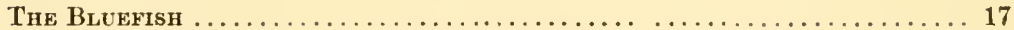

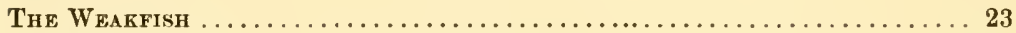

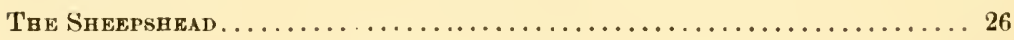

The Kingrish. . . . . . . . . . . 33

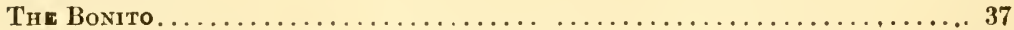

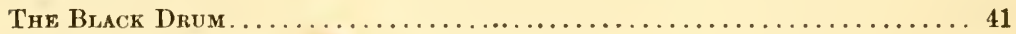

The Spanish Mackerel. .............................. 47

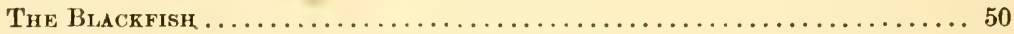

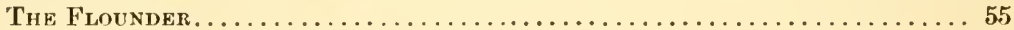

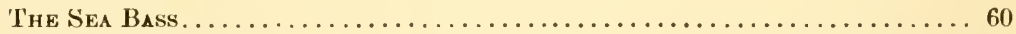

The Bergall . . . . . . . . . . . . . . . . . . . 64

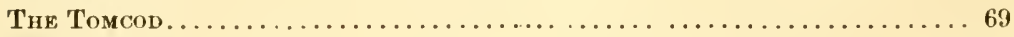

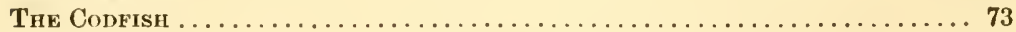

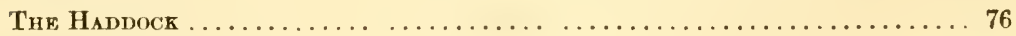

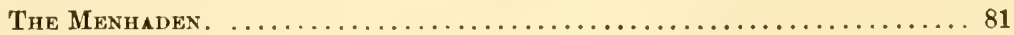

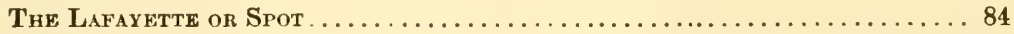

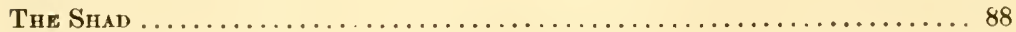

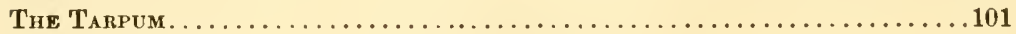

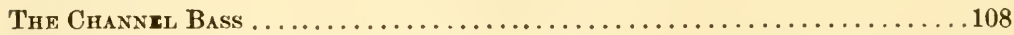

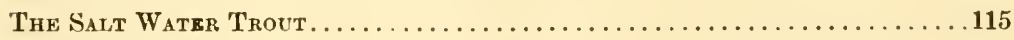

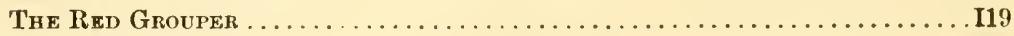

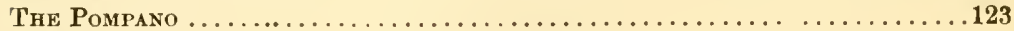

The Mangrove Snapper. . . . . . . . . . . . . . . . . . . . . . . 129

The Ladyfish . . . . . . . . . . . . . . . . . . . . . . . . . . . . . 135

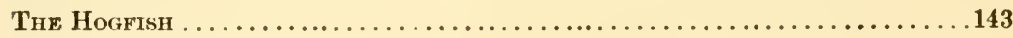

The Salt Water Catfish . . . . . . . . . . . . . . . . . . . . . .

The White or Silver Mullet.................................. 151 


\section{THE FISHES OF THE EAST ATLANTIC COAST.}

\section{CHAPTER I.}

The Striped Bass.-Romrisin.-Pircens linealus.-Gill.

No similiar stretch of coast in the world is as plentifully supplied with fish life as the eastern seaboard of the United States. From the tepid waters of Florida, all along up to the icy waves washing the Banks, myriads of fish exist, either to give pleasure to the angler or profit to the fisherman. At the head of the list stands the striped bass. Every wielder of the rod would put him there willingly enough, even if the authority of Genio C. Scott and Frank Forcster did not sanction it. The former is more enthusiastic over its many virtues as a game fish than he is over any other creature that wears scales, either of the fresh or salt waters. The latter ranks the striped bass second only to the salmon, dividing the honors perhaps with the black bass of the St. Lawrence.

The striped bass-Roceus lineatus-Gill, is known south of New York as the rock-fish, from its habit, probably, of swimming among the boulders of a rapid tide-way, nosing about for some dainty morsel with which to satisfy his appetite. To the ordinary gazer of the stalls, the striped bass would appear as a silvery fish marked with lateral black lines and possessed of a capacious mouth well supplied with teeth; but such a description will not answer the requirements of the scientific as well as practical angler of to-day.

The body of the striped bass is long and symmetrical, slightly humped over the shoulder, and marked horizontally by seven or 


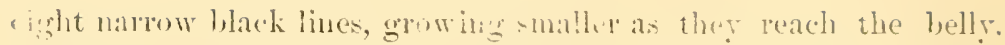
The wibh of the boly is two-serenths of its lengthe which is alont four tines the length of the hemb. 'The month is extmordinarily large, and besides the usnal teeth of the inside rim there are two patches on the tongue. The eye is larese and well roundert, giving an index of the bohn nature of the fish. The color of the striped batss as white molerneath, merging to a silvery aspert, then 10 an alive hue, and over the dorsal giving place to a metallic blue. There are two dorsal fins, the first has nine mpincs, sharp and strung; the sccond has one spine and twelve soft rays. The anal the which is moderately large, has three spines and eleven soft rays.

The striped bass varies in size from cight-inch litte follows up to monsters of bane hundred pommes. The greed of all sizes in, howe rer, the same. 'Those of three and fom pouncts run in company, and hence are popularly known as "school bass;" these it is that gives

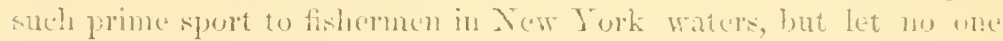

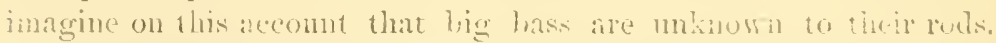

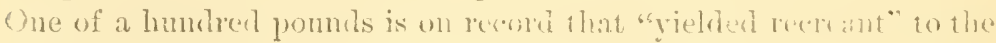

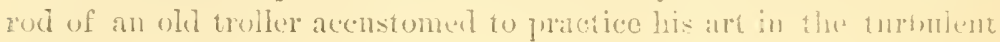
waters of Holl-Gite.

The "rum," as it is called, of bass commences in the spring months, and about the tenth of Jume the larre ones begin to reich onr markets. The cantme of "school bass" sontinnes throughont the stmmmer, and about the ent of August the celebrated stirf-fishing conc: in vogne. The striped loss muns me the extraries and rivers to deposit its spawn, and sometimes ascends even to fresh water. This amual movenent of the bass commenees in the spring, and fishing is grood until November.

As beseems such a noble fish, the striped bass reaches jerfection of size and conrage in the midst of strong, sweeping tides, in the clear, deep waters of the Somt, and along the mgged rocky benches of the ocean side of Long Islanil and Martha's Tincyard. Such hunting gromnts could only prodnce stich a tish as the bass, which andeed shows the effect of their surroundings in his shape and movements. IIis hard, muscular, well-rounded body, his large, bright eye and rapacious-looking mouth, warrant us in aplying to him Frank 
Forester's expressive sentence: "The striped hass is the boldent, bravest, strongest and most active fish that visits the watcrs of the midland States."

Every extensive work on angling in American waters contains a reference to the striped bass fishing to be enjoyed in the water: about Manhattan Island. The great depth of water : nd the narrow rock-strewn channels combine to form a very paradise for the bass, who seems to find the greatest enjoyment of his existence in darting through the Hell-Gate mill-race and among the rapid tide-ways of the lower Sound. Twenty ycars ago the striped bass fishing in New York Harbor was simply superb; every flood tide would see the rapture of hundreds of bass in their season. There was one place in particular, the mention of which will perhaps recall to many an oldtime angler some of his fishing trumphs-_"The Willows," as it was termed. This famous spot in the Harlem Kills was often so encircled by row boats that any late arrival on the ground was forced to push his boat stern foremost into the crowded ring.

As New York waters were and still are the center of striped bass fishing, I will first describe the methods of fishing here and the tackle and baits used. As the monster fish of former days are not now looked for, the New York fisherman fixes his rod and line for bass under teu pounds.

The kind of fishing most popular in our waters is "trolling." By some the rod is used, but oftener we see a solitary boatman leisurely rowing and holding a long and heavy line in his teeth (a sure sign, I take it, that they are his own). How anyone's jaws can stand such a strain I do not know; no doubt, though, enthusiasm gives them three-fold strength. I have seen such a lone fisherman rowing along with the stillness and imperturbable gravity of a Sphnix, suddenly drop his oars, take the wet line from between his teeth and after a struggle bring to his basket a three or four-pound striped bass. Imagine what a tooth-pulling strike such a fish must have made.

Trolling for bass in the channels of New York Harbor is more work than sport, and requires too little skill to suit the accustomed wielder of the fly-rod. It is the way though by which most of the large fish are taken, and therefore is worthy of notice. The best 
stage of the tide for this mode of fishing is during the last two hours of the flood. As to tackle, some use short rods, some long rods and some, as I have said, no rods at all. The rod, however, should be strong and supple; all sellers of fishing tackle have assortments of striped bass rods from which the angler can easily get one meeting his ideal of what a rod should be. The line, usually of linen, should be at least two hundred feet long. The sinker gauged according to the force of the water, must keep the line about four feet from the bottom. A leader is always used, made of double gut and arranged to carry one or two hooks. This leader is generally about four feet long; if one hook is used it may be shortened; if two hooks, then two pieces of gut are tied below the sinker, one being the first length mentioned, the other two feet in length. What is very essential is that the tyings should be as neatly made as possible, as the striped bass is a wary and shy fellow. Now, as to bait, shedder crab is tempting but not serviceable, the swift current gradually washing it from the hooks. A better bait is the long red sand worm looped on the hook so as to writhe with facility, thus as any one can see, making a most killing lure. These worms are found often nine inches long and as thick as the little finger. The tail of the squid is frequently used in trolling for large bass with heavy tackle. The seasons for trolling are June, July and August, and the places nost frequented by bass are along the sedge-covered banks, about sunken meadows and in swift race-ways of the tides.

The next general kind of bass fishing is that styled still fishing. Let skill and fancy select the reel accurately balanced, the rod strong and yielding, bright polished guides, large enough to let the line run smoothly, and an evenly twisted line. The angler will need these qualities in his tackle, for long casts are essential to successful still fishing. The leader is the same as is used in trolling, joined to the line by a swivel sinker and holding two "flatted Kirbys," size.0-9, this being in my estimation about the proper hook for still fishing for school-bass. The best bait is the shedder crab, next the shedder lobster, and last but almost equal in efficiency to the other two, the sand worm.

The striped bass, like its brother the fresh water striped bass, will 
take the fly eagerly, and in doing so will give more excitement, perhaps, than genuine pleasure to the enthusiastic fly-caster who is unwilling to place any fish under the heading Game, before he has assured himself that the member of the finny tribe in question will seize a surface lure in the shape of an artificial fly.

In all salt water fishing, with hardly an exception, the hours when the tide is rising afford the best scoring time, and this is invariably true in striped bass fishing. In fly fishing for the bass the top of the flood is the right tine, a little before the tide will turn. The angler may stand in the stern of the boat while the boatman rows him abont over the flooded flats and still waters near the shores. A large fly must be used, a red ibis or a red and white one, in fact any of those bright ones used in salmon fishing. It will sometimes be well to let the fly sink beneath the surface six or eight inches. All of the above methods of fishing are tame and commonplace compared with that acme of all angling on the Atlantic coast-surf fishing for the striped bass. It is also called "chumming," but the "chumming" part of the sport is not performed by the angler. This surf fishing is limited to a stretch of our Eastem coast, whose northern limit is Cape Cod and whose southern is a little below Montauk Point. The description of this wilely celebrated branch of salt water fishing, though it is known perhajs to every angler, could not well be omitted in anything written about the striped bass, it is such magniticent use of skill and tackle, such splendid practice for the museles.

Running out from the shore, right in the midst of the rolling surf and over the great boulders, a light frame work or "bridge" of wood is built. It terminates in a small platform affording just room enough for the fisherman and his attendant. I mentioned above the necessity for the best of tackle. Now the need is doubled. The rod is nine or ten feet long (each angler is sure to take the length he can handle best); the reel, a triple multiplier of largest size, must be most beantifully and perfectly balaneed in its movements; the line, some four hundred fect long, is of the best linen make. All these things must be well looked to, for they are indispensable in casting. Ife who maker the longest easts, takes the 
most and largest fish. To be suceessful in any degree the baits. must be shot seaward over one hundred feet.

There are two general methods of casting - the "overhand" and the "underhand." These terms have reference to the way the rod is lield in easting, either over or mder the level of the arm.

Before the angler launches his bait on their long trip througl the air, the "chummer" has eut up into pieces enough menhaden to fill a bushel basket, and with a long sweep of his arm is scattering the bits of fish over the waves. Besides the menhaden being a favorite side-dish of our friend the bass, the oil of the fish covers the water for some distance ont. This film whets the appetite of the striped bass, tempting him further in, till suddenly a great piece of crab or an entire lobster's tail splashes down right in front of his open jaws. It is no strain on any one's imagination even though he has never "been there," to try to picture what a gloriously exciting and hard-foright struggle there will be before his hungry lordship is brought within the reach of the gaff. The splendid fish, thoroughly game, full of the rush and exhilerating life of the salt waves, his firm museles trained by many tussles with the boisterous tides, is able to make a fight for life exeecling in length and fiereeness that of any other game fish of our continent. The angler, on his frail platform, barely giving him space for action, out over the combing breakers that now and again drench him with spray, is also spurred by the excitement of the moment and its surroundings to use his utmost skill and art. The combined result is what the salt water fisherman elaims the right of terming the high water mark of all angling.

In order to enjoy this noble sport where the fish has a better chance of escaping than the angler has of eatehing him, safe from intrusion, and also that they may have some prospect of success, parties of gentlemen have formed clubs and purchased parts of the coast line and among these fishermen an earnest rivalry exists for the proud possession of the title of "high-line," given to him who takes the largest fish or the greatest number.

Perhaps some over-fastidious angler will object that this surf-fishing is a mere contest between heavy tackle and brute strength, but the objection will not hold good, for in no branch of the angler's 
art is there snch oprentmity given for work of heat and hand as in Inacling a chent striped bass whose weight is out of all proportion to the tackle nsed in his capture.

The time of year when anglers can most enjoy this surf-fishing is in the months of Angnst and Septemlier; the bait they use is the oily menhaden, the shedder crah, and as something new, the meat stripued from the tanl of the lobster. The places they go to are Montauk Point and its vicinity, Block Island, Martha's Vincyard, the Elizabeth Islands, and the rocky shores of Connecticut and Massirchusetts.

For smaller bass any of the bays of South Long Island, along the New Jursey coast, the pleasant inlets of the river at the Somd, and the larlem Rivel at Fingrbrige, the East River at Icll-Gate, at IIarlem Kills, the North River ny to fresh water, are good grouncls. The tackle for this lighter fishing I have already dereribed under" "trolling." The baits are shedder crab, sand-worms mul sherdler lobster.

I have touched here and there unun the virtues of the striped bass as a game fish. I will add another to that long list by mentioning the splendid thavor of the fish whin righty served. By all means then, re angler who like fish conked as well as (I will not say-better than) fish alive, let the strijeri hass of four pounds weight be gashed and hoilda, served on a liot dish, sprinkled with a mere daslis of red pernes and hitered well, and then eaten with the ardution of a few drops pressed from the malf of a smooth-skinned lemon. Truly you will enjoy a taste jutting the fried Sadulle Rock to shame, and making the camvass-backed duck hide his diminished biall. 


\section{CHAPTER II.}

THe Bluerish.-P'omatomus's saltatrix. -Gill.

The bluefish, at once the most destructuve ard orn si the most important, from an economic point of view, of all coast fishes, is next on the list of gamy denizens of the sea.

The bluefish has not always been taken on the North Atlantic seaboard of the United States, but mate his appearance there for the first time during the first decade of the rentury. But since that migration from more Southern waters, vast schools of bluefish have swept along the coast of the Atlantic States year after year, without a single season being omitted. It is thonght by many that this rapacious forelgner came from the warm seas surrounding the West Indies. Be that as it may, he certainly has the bloodthirsty habits and murderous ways of the Spanish buccaneers, who once infested those islands.

The bluefish in his ammual visits, as some one has recently estimated, slaughters billions of the smaller fishes, killing in mere wantonness. He drives before him immense sehools of the mossbunkers, and anon dashes into their midst, cutting right and left with his sharp teeth. They do not eat one-tentl of what they slay, but for the most part take one round, clean bite out of each vietim, leaving their bodies to float on the waves, "a prey to the birds that sail in the air." It is this fact that betrays the whereabouts of the bluefish; for the long-winged gulls hover above every school of them, picking up the floatung crumbs in the shape of dead fish from the bluefishes' cable. The fishermen on shore watch till they see the gulls sailing 


and dipping, and then know exactly where the bluefish are at their murderous work.

The run of these fish commences in early spring, and lasts through the whole summer and fall, but in winter the fish disappear.

The appearance of the blucfish is rakish, as bescems the pirate of the ocean. His bouly is bounded by graceful curved lines; the fins are small, consilering the great strength and speed of the fish, and look when spread out as if they had been trimmeel. The tail is forked; the first dorsal fin has seven rays, and is much smaller than the second, which has twenty-five rays. The ventral fin is small, and has five rays. The anal fin is larger, and about the same size as the second dorsal. The operculi, or gill covers, are covered with scales; the mouth is very large and its edges are full of very sharp teeth, good to tear and cut (hence one of its scientific names-temnodon). The head is more than one-fourth the length of the body. 'The whole fish in form is beautiful and symmetrieal. The color is white, or greenish white on the belly, gradually deepeuing into a steel bluc as it nears the dorsal fin.

Of the varions ways of taking the bluefish I will first describe the most important tn all classes of fishermen-trolling with hand lines. There are some who think no true angler will take aught but the salmon or the black bass ; there are others who limit the angler's skill to easting the artificial fiy ; there are many more who will allow him no "gentlemanly" metlod of fishing save with the rod. I think they are mistaken as well as selfish. I would give as a truer definition of the art : fishng of every kind requiring skill and carried on humanely and for enjoyment. If, then, the "gentleman angler" will not feel less of the gentleman while trolling, he may enjoy the delightful sport in the following way:

Have a statinch fast-sailing catboat or sloop, one that will "turn on a shilling," as the phrase goes, and a good-natured old sea-dog to handle it. In a good breeze he will make his craft tack to and fro. through the shoal of bluefish, jamming the helm hard down and caus ing her to spin round withotit losing headway.

The next requisite is a good stout line, generally of cotton, two or three hundred feet long, carrying a heavy sinker, and below this 
a trolling spoon of ivory, bone or metal. A trolling sinker is made sometimes with a large hook set in the lead. Trolling spoons are of great variety, very costly ones being made of silver and pearl. The crolling sinker or spoon must be attached to the line by a yard length of wire snell, or the two will soon part connection, aided by the sharp teeth of the bluefish.

To protect the hands of the angler, woollen gloves are often desirable. When the bluefish strikes (fiercely, he does, too, and feels the hook, he begins a fanous fight, sometimes running deep, then breaking on the surface, and sometimes surging from side to side. A well-known trick of his is to start off at lightning speed and overrun the hooks.

Fish caught by trolling run from four to fifteen pounds in weight, and this method of fishing gives great enjoyment. Overhead the blue sky and soaring gulls; the sparkling waters all about; the swift motion of the boat and the excitement oi the eapture, make the hours pass most delightfully.

Another good way of taking the bluefish is by chumming. Moss bunkers are ehopped fine, as in striped bass fishing, and thrown upon the water. The rod must have large free gnides, the reel be free run ning and of fine workmanslnp, and the swivel sinker light. The bait, a piece of menhaden or crab, is cast out in the midst of the chum-bait and then reeled in bluefishing the hooks must be fastened to the line by a piece of fine wire or gimp snell.

The best starge of the tide for bluefishing is the rising tide and the slack water at the clob and flood.

The bluefish will take the fly and often keep it. If you have any to bestow, he prefers the large oncs, of bright and assorted colors.

Where to enjoy bluefishng is easily told. In the Ocean off Cant: May, at Long Branch, and all along the coast of New Jersey. Excellent fishing is enjoyed every season at Barnegat and Atlantic City, at Fire Island and on the whole stretch of the Ocean side of Long Island. The natural food of the bluefish is the mossbunker, and unless snmething in the shape of legislative action is done to restrict the taking of these fish wthin a certain period, the mossbunker wil: 
be almost annibilated, and the attraction which draws the bluefish to our shores will be a thing of the past. This is a matter not only of much concern to the angler, but vastly more important to the poor of our great seaboard cities. 
The Weani 1sll._- C'moscion regalis.-Gill.

The fish we now treat of is by far the most beatiful specinen of the inlabitants of the sea which the salt water angler has the happy fortune of capturing. Though he cannot lay claim to the game qualities of the striped bass, upon his scales shine each of the seven cardinal hues.

The general color of the weakfish, or as the Indians called him, the squeteague, is blue, lightening on theounder parts. On the back and sides are spots arranged in a transverse order. 'The color of the top of the head is greenish blue; the inside of the month yellow; the gill covers lustrous silver; on the lower jaw there is a salmon tiut. The fins also are of different coloration; the dorsals are brown; the pectorals a yellowish brown; the ventral and anal are orange. On both sides of the head, upon the operculi, are two rudimentary flattened points.

The first dorsal fin is composed of eight rays, which might with propriety be called spines. The second dorsal is composed of rays nuch divided. The pectoral fins consist of seventeen branched rays. The ventral fin of one ray and five imperfect rays, and the caudal fin has serenteen rays.

The weakfish gives amusement to more anglers of the metropolis than any other fish on our lists. They run in great numbers durmg the summer months and early fall. July, August and September will be found to be the most successful months for weakfishing. Into every shallow estuary and creek and tide-chanuel the weakfish 


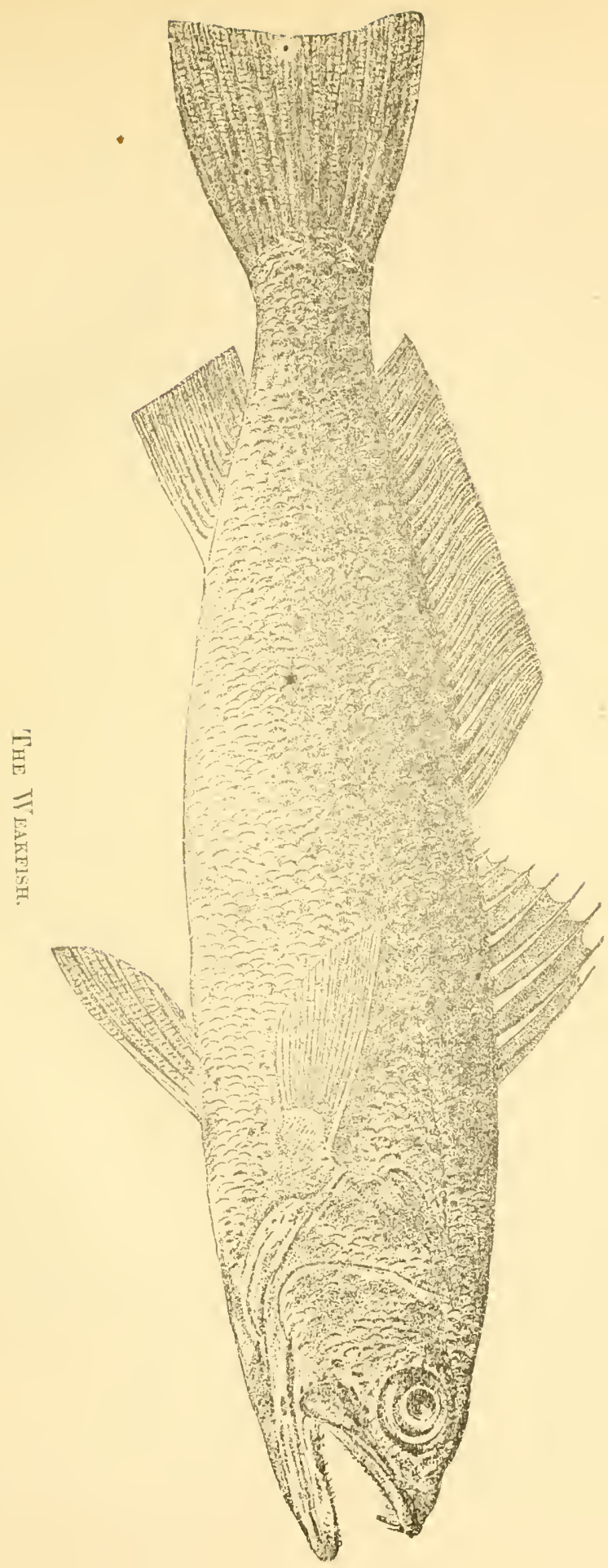



fwarn and it is their habit to run in from deep water on the nncoming tide, the large ones swimming four or five feet below the surface.

Before the rapacious bluefish came from the South in such numbers and regularity, the weakfish were much more plentiful on our coasts, and though it is a sort of post hoc mop hoc argument, yet many claim that the gradual decrease in the supply of weakfish is due to the bluefish's adrent.

As above stated, the weakfish can be taken almost anywhere on the Atlantic coast from the Chesapeake Bay up to the Connecticut river, and a few of the best places to take them are the following:

Princess Bay, reached by way of the South Ferry; Fort Lafay'tte in the Narrows; Newark Bay; up the Long Island Sound at Westchester Creek; at Atlantic City, and at the mouth of the Delaware river.

The nearness of many of these places to the great eities, New York, Brooklyn and Philadelphia, gives an opportunity to the angler with little leisure to take his day or two of tishing in the tossing occan and take what he catches home with him. It would be best, too, to do this last as soon as he can, for the weakfish unless eaten while yet the brilliant tints shine on his sides is of a poor and insipid flavor.

The weight of this fish raries from two pounds running close in shore, to those of eighteen pounds, rarely caught, and that only in deep water.

IV eakfishing is generally carried on from a boat anchored in the tideway and the best stage of the tide is the flood tide, and especialIy the last half of it. It affords the most sport to fish for the equeteague with a light bamboo rod; with a rod his eapture is more certain, and it is not true fishing to take a clelisate fish like the weakfish out of the water with a heavy hand line, though perfectly allowable in the case of the fierce and weighty bluefish.

The reel should be large, the same as is used in fishing for the small striped bass; the line, a fincly-twisted linen one, light as nay be consistent with strength. The lighter the line the lighter the 
sinker, is a rule of great consideration in salt water angling. A light swivel sinker is used, and a leader, npon which two hooks of large bend are fastened. An excellent hook is 4-0, best hollow point Limerick. 'The best bait is the shedder crab, and among other baits hard clam, shrimp or a piece of menhaden or other light colored fish.

If you are fishing for the smaller weakfish make a cast and then allow the sinker to remain off the bottom three or four feet. If in the tide-mas and for larger game, it is well to nse a float which will hold the baits some five feet below the surface.

The weakfish bites fierecly and makes a brave fight, and his favorite tacties are to run with the line faster than it is reeled off, to orerrum it, as the angler terms it, and so slake out the hooks. 'This operation is made easier by the fact that the jaws of the weaktish are parehment-like and in them the hook makes a large rent, being stayed only by the stiff rim of the mouth. In weakfishing, then, the - anre to keep, the line taut. 


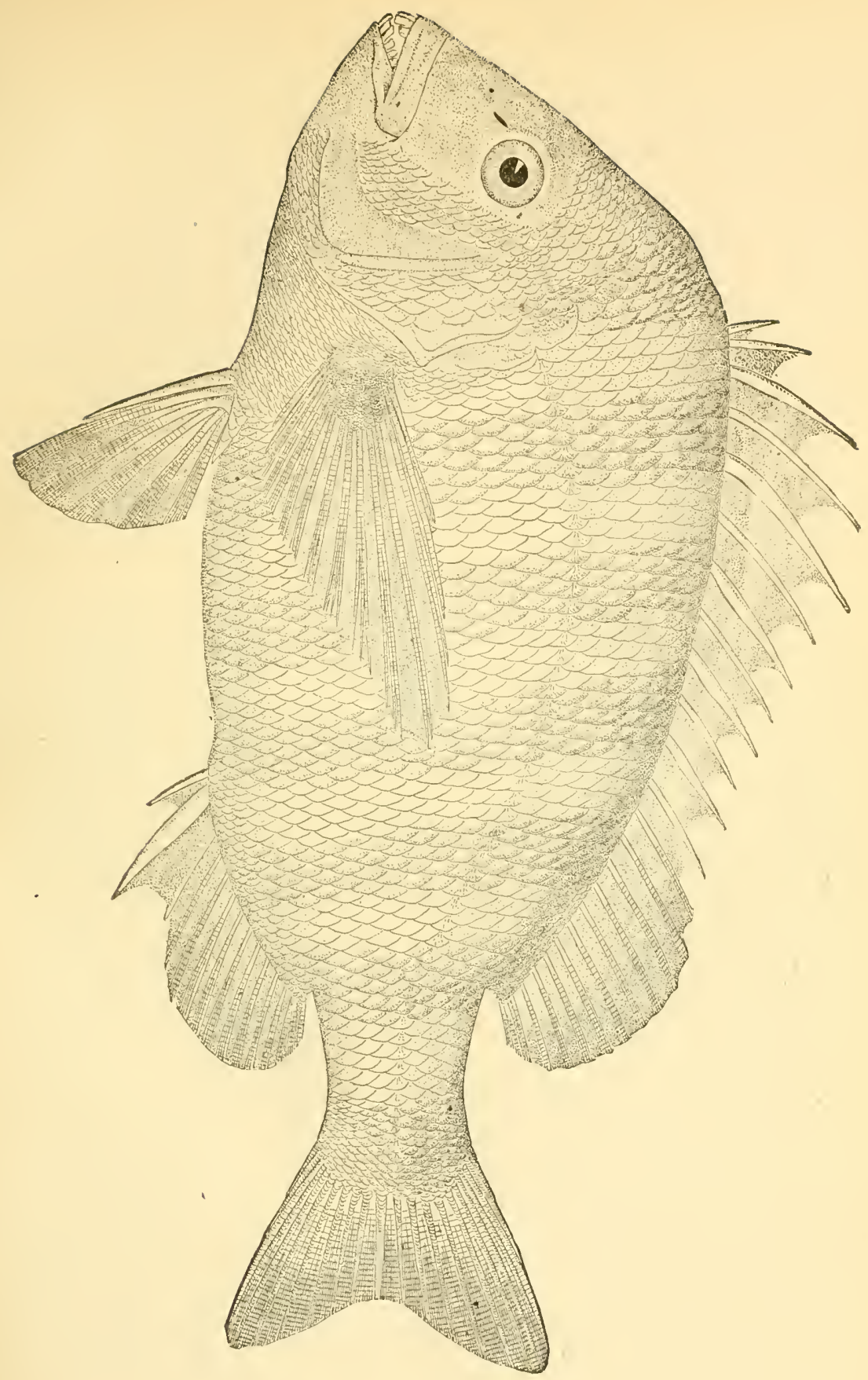





\section{CHAPTER IV.}

The Shemphead.-Arehosargus: mobatocephalus:-Gill.

The fish we now treat of is the greatest delicacy, according to many, which the sea yields to man, but whether it ranks higher in this respect than the Spanish mackerel or the pompano, I think is very doubtful, but de gustibus there is no dispute. The flavor of the sheepshead is however acknowledged by everyone to be most excellent. The appearance of the fish is most peculiar. The head is large and massive, and the back greatly arched at the shoulders, and along the most of its length is placed a large dorsal fin, which the sheepshead can raise or lower at will into a groove where it fits neatly. I know of no other fish whose scientific name is a direct translation of its common and local appellation-(probatocephatus is sheepshead turned into Greek). This coincidence is caused by the marked resemblance between the front teeth of the sheepshead and the land ovis. The tooth system of the sheepshead is remarkably well developed ; besides the front incisors (six or eight) there are molars powerful enough to crack a clam-shell with ease. The color of the fish is brassy on the dorsal ridge, merging into dull silver, which gets lighter as it nears the ventral line. About the body at right angles to the medial line run six dusky bands; the eye is large and gany. The dorsal fin is composed of twelve spines and twelve rays. The pectoral fins are composed each of sixteen ramose rays. The ventral ray consists of one spine and five rays; the anal fin of ten softrays. Upon each shoulder is a dark spot. Altogether, the sheepshead is 
one of those beautifully colored, toothsome fishes which only salt water holds within its depths.

'The sheepshead runs in size from half a pound up to fifteen pounds, and like most of the other coast fishes, is a summer visitor ; appearıng in June and leaving in November. 'This fish runs up from the South, and increases in size as it nears our waters. The sheepshead is not seen above New York State. Though he seldom appears in such numbers as the bluefish, or even the weakfish, yet sometimes the sheepshead eome in great sehools, and happy is the fisherman who falls in with such a collection of them. It is a thing to boast of, the capture of a large sheepshead.

The front teeth of the sheepshead are wisely given him for a special habit of his; he swims about sunken logs, along the bottom rocks, and is enabled by his projeetming teeth to bite off the different molluses which form the food of the sheepshead. This grazing habit of the fish has given rise to an arrangement on the Virginia coast by which the certainty of an annual call from the sheepshead is secured. A writer in the first volume of 'The ANgIer has well described this plan :

"The natives drive long stakes of split wood into the bottom of inlets and sounds in square or cireular shape, forming pens. On these stakes the molluscs soon attach themselves, and the sheepshead finds in or about them an attraction habitual where he can eat to his fill without beating about for the delicacies he demands."

Sheepshead are eanght by hand-line and with rod and reel, and of the two methods of course the skillful angler will chose the latter. The sheepshead is a wary and careful fish, and to draw him from his native element requires skill and patience. The rod should be a stout one, and about nine feet long-the regulation striped bass rod is about right. The line most thought of by sikilled sheepshead fishermen is a braided linen line of the smallest diameter giving strength enough. To this line is fastened a swivel and tracing sinker, and also a double gut leader composed of two parts, one of which is about two feet in length, the other twelve inches. 'The best bait is the soft clam, either put on whole or with the shell removed; the next best is the shedder crab-(is there any living sea animal that. 
won't take it?) The hooks are made of stont wire, short shank, and ringed. Most tackle dealers sell a sheepshead hook. The reel ought to be a multiplier, and about the size used in bass-fishing. On making a cast the sinker is allowed to find bottom, and then the line is drawn tant. The sheepshead is a cantious nibbler, and the taut lne enables the fisherman to feel his slightest nibble at the bait. On being hooked the sheepshead will come up without making much fuss, but when near the surface of the water will often sink like a shot.

The best places to take the sheepshead are the following : On the New Jersey coast off Long Branch; at Barnegat ; off Atlantic City; at Rockaway Beach, and in the Sonth Bay.

The sheepshead is heavily armored with scales, and a landing net is a necessary part of the angler's outtit. 


\section{CIAPTER Y.}

The Kingersu.-Mentivinens nebulnsus-Miteh.

The kingfish, or whiting, as it is called stong the southern coast, is the gamiest fish for its size known to the angler. Its great gaminess, its beanty of coloring and form, and its excellent flavor combined to cause the loyal citizens of New York in the colotrial days, to name the fish the king-fish.

It used to be very abundant in the waters of New Tork city, and with the small striped bass, was the erowning glory of the old time fishing. In such esteem was the king-fish that $I$ have read in some fishing book that the New York angler on hearing that king-fish were to be caught from the pier-heads, would seize his rod and basket and rush off in his shirt sleeves to enjoy the long wished for sport.

But now the kingfish are very searce in our larbor; but there are plenty of them to be bought in Fulton Market, having been brought ap to the city from the Jersey coast and the South Bay. Genio. C. Scott is very enthusiastic about the kingfish, giving it a very high rank among salt water gane fishes; and he makes the assertion that the New York angler cares more for a two pound whiting in his oasket than (well I have forgotten how many pounds of any other salt water fish.) But without claiming as much as this for the kingfish, he is worthy in every respect of the high esteem in which he is held by anglers and epicnres.

The kingfish, also sometimes called barb, is tapering and long in form, has a complete covering of round and ciliated seales, and on 


the gill cover are two stout flattened spines. The head and mouth are small and the snout well thrown forward. The teeth in the two jaws are not alike; in the upper jaw they are long and acute; in the lower they are short and bent inward. There are two dorsal fins; the first is a triangle and is remarkable for the height of the first. ray. The second dorsal is long and low; the pectorals are wide and pointed. The anal fin is composed of one spine and eight, rays. The tail is curved in and then ont like the letter $\mathrm{S}$.

The kingfish glows with many beautiful tints; upon the baek and sides are shades of grey and silvery red: the abdomen is blueish white and the fins are of different colors. The first dorsal fin is brown; the caudal and pectoral fins are olive brown; the ventral and anal fins are yellow. On the sides above the lateral line are many dark stripes or rather bands, hence nebulosus. It is a summer fish and runs in July and August, and in its wanderings it never goes beyond Cape Cod.

The kingfish, as I have said, is very rarely met with about New York, but further south, at the inlet and along down to Florida they are very plentiful. A light rod and multiplying reel, a strong and very light line, a swivel sinker and two rather small hooks are what is required in the way of tackle; much the same rig as is used in weakfishing. The bait either shedder crab or sand-worm. The kingfish is thoroughly game; he seizes the bait fagerly and then goes to the bottom, following up this movement with long runs from right to left; it is really remarkable what a determined resistance the little king-fish will make. In size he varies from one to six pounds, the average beng two or three pounds. The time to fish for them is when the tide is running in. Kingfish can be eaught along the south side of Long Island, off the Jersey Coast, at Atlantic City, Long Branch and Barnegat Inlet, and further south they are very common. 


\section{CHAPTER VI.}

The Bosito._arda pelamy:-Gill.

The bonito, or skip-jack as the fishermen call it, is a wanderer in all the warmer waters of the world. It is a species of tunny, supposed to have been first seen at the Islant of Sardinia. It is plentiful in the Mediterranean Sea to this day ; is found off the east coast of Africa, in the waters of South America and all along our eastern coast. In appearance the bonito resembles the members of the mackerel tribe, but on a second inspection is found to be vastly stouter and heavier in proportion to its size.

Its symmetrical form and sharply ent fins give it an appearance of yreat speed, and its sharp teeth a rather vicious look. It is nearly ore-quarter as broad as it is long. The scales on the bonito are so fine that they are scarcely visible to the eyc. The mouth is well supplied with teeth, each jaw has about twenty fine acute teeth, slightly inclined inward, and at the base of the tongue there are two patches of small teeth. The eye is large and prominent. The first dorsal is long and consists of twenty-one weak spines; the seccond dorsal is rather small and has two spines and a number of rays; behind this fin are nine finlets. The pectoral fins are long, triangular and lodged in a cavity fitting their shape. The ventrals also have such a hollow into which they fit. Between the anal and the caudal fin there are six or seven finlets. The caudal is curiously curved inwards, about the shape of a crescent.

The top of the head and sides are dark lead color. The belly is an ashen grey, almost blue in some places. The ventral fins are 


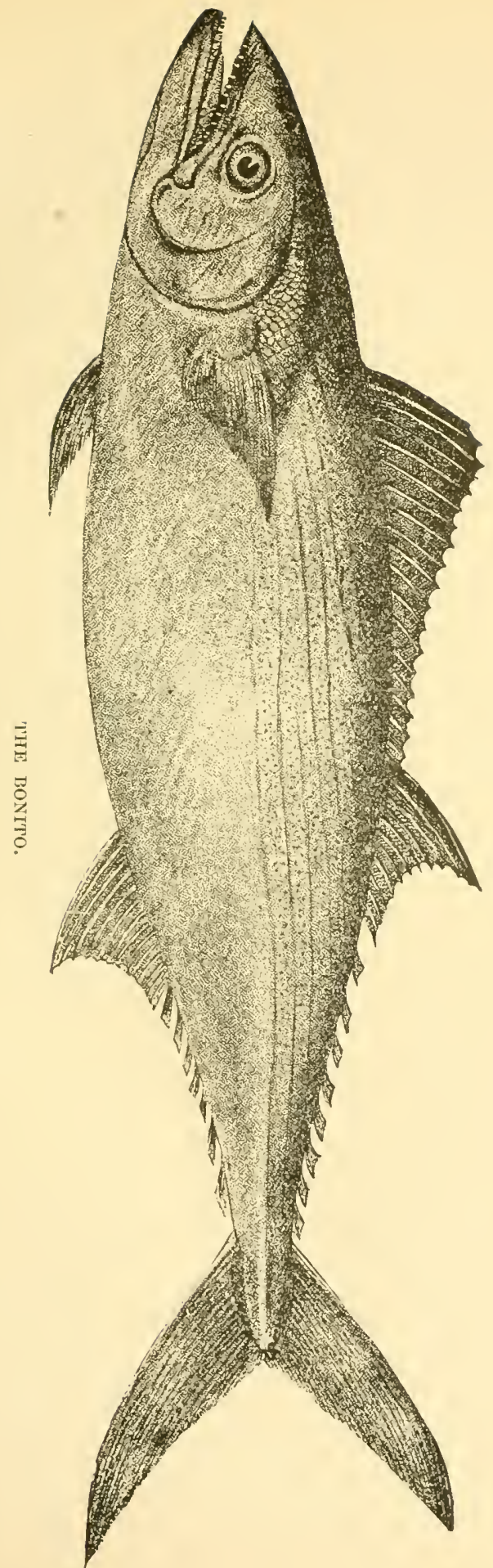



white and the other fins are black or a lark blue color. Upon the silch are six or eight stripes paralled to each other. 'These stripes alone should serve to identify the fish. The bonito visits us in Angust and September, at the same time as their nobler brother, the spanish mackerel, and these last being worth in the market twenty and twenty-five cents per pound and the bonito about six cents, there is a vast deal of imposition practiced by the marketmen, especially the smaller dealers outside of the market. The two fish look somewhat alike but their flavors are miles apart. The bonito is contse and not very good, but the Spanish mackerel is one of the greatent Juxuries taken from the sea.

The bonito is frequently canght by blue-fishing parties; it takes the same bait as the bluefish and often accompanes the bluefish armies, anil also sometimes travels in large schools of its own kind. In trolling, which is the only way of taking him with the hook, he seizes the bait with a snap and makes almost as much of a struggle as the hluefish. Those eanght for the market are taken in seine nets and when honestly sold are very cheap. Cape Cod seems to be their northern limit, and they are plentiful in the summer months iu Massachusetts Bay. 


\section{CHAPTER VII.}

The Brach Drux.-Pogonias thromis-Lacep).

The drum is the largest fish eanght with hook and line that visits the Eastem coast. Of this fish there are two distinetly different varieties, distingnished by the coloring. The black drum and the red drum, although thus differently marked, are not, as many suy pose, two separate kinds of fish, but are species of one and the same class. The so-called "banded drum" is not a member of this class, but belongs to a totally distinet family - that of the Curcirer.

In the months of August and September these "heary-weights" of the angler's list arrive in swarms, or rather in small companies. off the Jersey shore. The ảrum is a social fish, and where you find one, you are pretty sure of finding others also; and so it often bappens that sehools of them are taken in the seine nets cast for menladen. Such as are caught in this way are ground up for fertilizing purposes; a great waste of a very good food-fish.

The black drum is a heavy, eompact and solid fish, of great depth as compared with its length. From the chm depend nearly twenty fleshy cirri. The body is eovered with a heavy coat of large and unsymmetrical scales, and on the gill-cover are two blunt points. Each jaw is well armed with blunt teeth, closely put together and eminently fitted to grind and ermeh. There are no teeth upon the tongue. A marked feature of this fish is the abundance of finpower with which it is supplied. First, there are two dorsal fins, very prominent when expanded, and fitting into a groove which is more developed for the first dorsal. The first dorsal fin is composed 


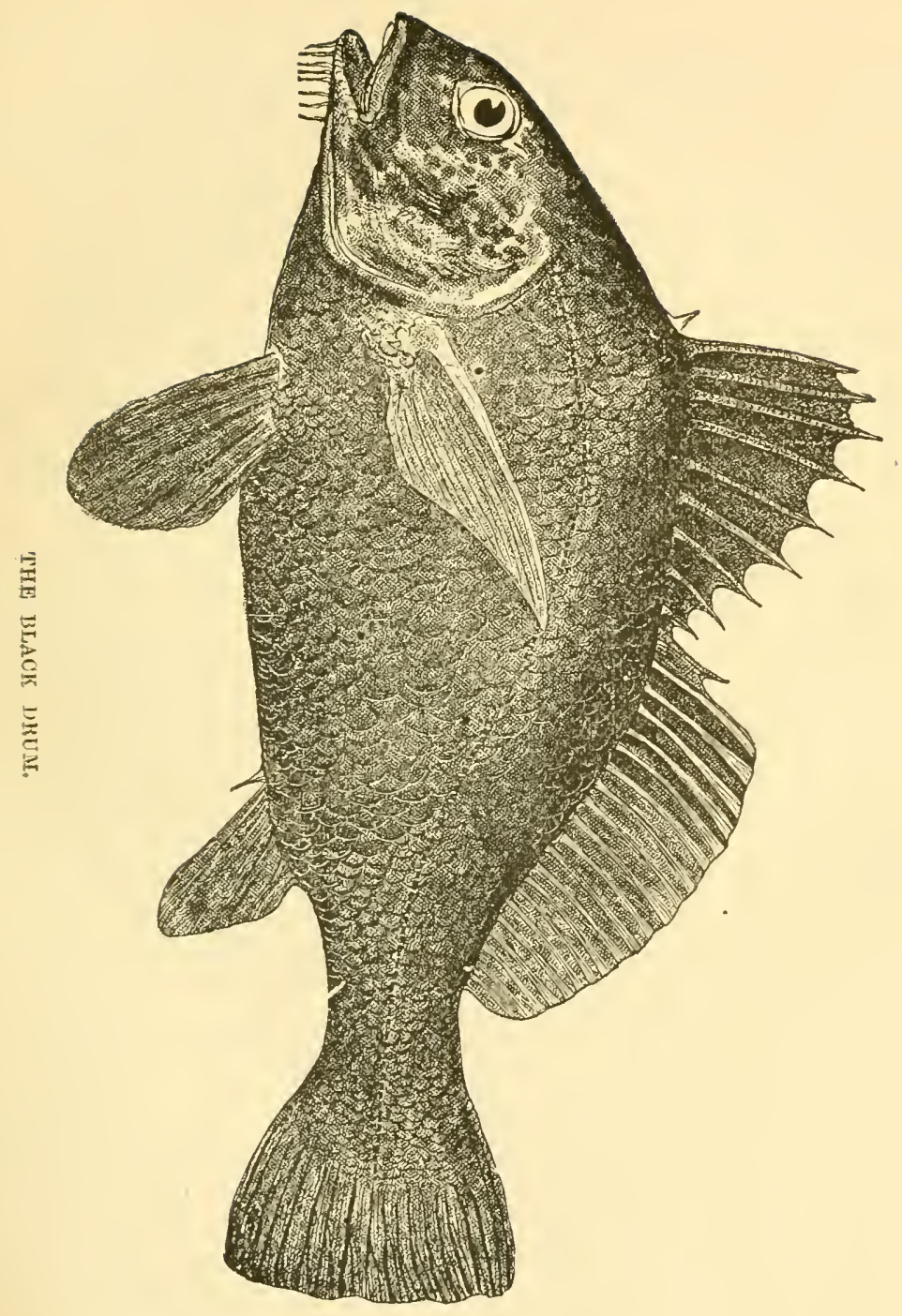



of ten stout flattened rays; the second dorsal, of one very short ras and ahout trenty soft rays. The pectoral firs are large and pointed; the anal fin has one very short ray and another long and stont one.

The prevailing eolor is darkish bronze, of a brown tint; lighten ingas it nears the ventral region. Behind each pectoral fin is a roum? dark spot. The scales are silvery on the exposed edges. 'The black drum, as it is called, is dark brown, rather than black, and the red Arum is lighter in tint, redish and coppery.

In size the drum rums from twenty to one huidred pounds and over, and their habitat is in extent from Florida to New York.

Ilost of the drum are captured in seine nets during the summer months, but the angler, (1)robably tired of troutlings and basslets, and following the example of the English sportsman who, weariec? of pheasants and jack-rabtits, jomrneys ovef half a world to find tigers and elephants) standing in the surf takes the monster ont of lin native element by a hay y combination of strength, tackle and skill.

lilack drum are taken from the that beaches of New Jersey while the tide is ruming up ; they are not found at all at chl tide. Evidently they rum ont into deep water, and follow up the incoming tide, seeking food, which is generally erabs, clams, molluscs and sanct insects of all kinds.

The drum is taken withont the use of a rol. The angler stanils on the beach at the edge of the surf, or a little way in it, and uses a long hand line-two or three hundred feet of Cnttyhunk striped bass line is about the thing. The line should be as light as is possible ini bringing in such big fish. To the line is attached a heary "east," or "bank" sinker, and above this lead are fastencel the hooks ; generally two are nsed, which are large-numbers 1 and 2 "sea hooks" are abont right in size. The bait used is either crah, clam (soft shell) or musel. The drum can crush almost any molluse with his powcrful teeth, and it is said he is very dentructive to the oyster farms. along the coast. The baitud line is cast far out in the surf by the angler, and as the action of the waves rolling in brings along with them the heary smker, the fisherman coils np in a round recepracle hanging from his neck the slack of the line. It often bay- 
pens that the bait is seized when there is scarcely enough water to cover the fins of the drum.

The drum bites at first rather gingerly, like the sheepshead but as soon as he feels the strain of the line he begins to pull away, and then as the angler gradually brings him in, the drum will commence a series of short runs, following each other gnickiy, and such are the staynig qualities of the fish, that a large one of fifty pounds weight will nake a heary pull for the angler. 


\section{CHAPTER VIII.}

\section{THE SPANISi MACKEREL-Scomberomorus maculatum-Mitch.}

'J 'he Spanish mackerel, the most delicate in flavor of all the salt water coast fishes (with the exception of the striped bass) deserves, mention in this paper both for his beauty and taste, and because a deseription of him will make the reader less liable to be imposed upon by fish sellers who are ready to palm off the bonito for the royal leader of all, the Spanish maekerel.

The fact is, that Spanish mackerel are not of ten taken by amateur anglers in the ocean above Cape May. Those in the markets of New York are either shipped or taken in seines in the lower bay and off the Jersey shore. The Spanish mackerel is far more elegant in shape and color than the bonito, as the following description will show.

The very symmetrical and rounded form of the Spanish mackerel gives the fish an appearance of swiftness and grace. The head is small and flattened on the top and the eyes are large. On the pectoral regions the seales are larger than on other parts of the body. There are sixty or seventy small teeth in the mouth. There are two dorsal fins, the first of which is transparent, and six or seven dorsal finlets. The pectoral fins are pointed. Behind the anal fin are five finlets. The caudal fin is deeply forked and on each side of it are small projections called by icthyologists carince, or keels.

The coloring of the Spanish mackerel consists of many diverse tints and gives the fish the most beantiful appearance. Above, on the sides is spread a light sea green, deeper in shade on the dorsal line, and there are darker green lines that go down the sides and just cross the lateral line. Beneath, on the belly the color is a dull 
blue, and on the sides are numerous gold spots, oval in shape. The abdomen is of a copper bue : the gill-covers are also coppery, in some lights refleeting a silver brightness.

The fact that the bonito has no visible scales, and is barred, not spotted, onght to serve at once to distingruish between the bonito and spanish maclierel.

When the spanish mackerel is taken by book and line it is while trolling. They do not run so chese to the shore as the bluefid, and this is why the angler so infrequently meets with them. Thongh somekntes eaught by fishermen while hluefishing, get when a trip is marde s peclally for the mackerel it is best to change the bluefish tackle, substituting a smaller spoon and lighter sinker. The Spanish mackerel takes the bait with a snap, makes a short and gallant fight, and when ho vields gives up thoroughly, having no more struggle in him. Off the Southern const I understand the capture of Flanish mackerel Fith hook and line is practiced frequent!y and with suecess. The Thaits used are the same as in bluefishing. and the months when the mackerel appear on the Jersey and New Iork coast are August and September.

The Spanish mackerel, like many other good fish, is a nomad, and is a travelt'l from warmer seas, having first been seen in the Metitermanean, and now being canght almost everywhere. In size they vary from one to six pounds; they come larger, but I never have spen any txceeding the latter weight.

The four fish, the drun, kingish, bonito and Spanish mackerel, are all highly ralued additions to onr fish supply. giving enjorment to the angler and food to the mant. They are all remarkable for the beanty of their coloring-it would be hard to find their equal in this respect among fresh waters-and it is a curious fact that the colors of salt water fish are less changeable than those of their fresh water brethren. Not only more unvarying are the tints flashing from the seales of the dwellers of the deep, but far more vivid. "The clear yellow of the pompano, the pure white of the striped bass, the deep red of the drum, and the metallic green and blues and silver of the bonito and spanish mackerel, have no rivals in the lakes and rivers of the inland 


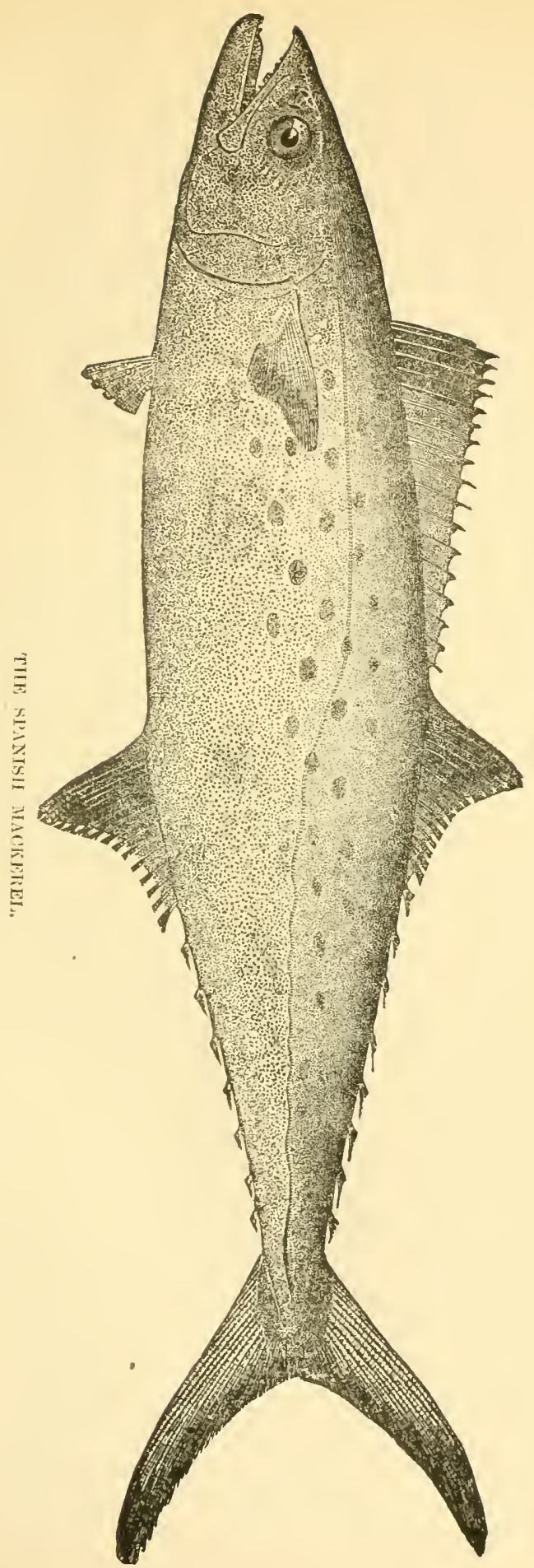





\section{CHAPTER IX.}

The Black fish-I'autoga onitis-Linn.

The fish we treat of in this paper are humbler members of the finny tribe than those mentioned in the first articles. They cannot lay claim to bezuty, nor to more than indifferent gaminess, yet they compensate for this great lacking by their number, their toothsomeness, and by the fact that they are the first to come and almost the last to go ; and also that they run nearest the great city, up to the very wharves, affording intense delight to the very lowest of the angling fraternity - the newsboy after he has sold his last paper, the bootblack whose jobs are few, and the market lounger who has come into possession of a lobster thrown out of one of the trim fishing smacks.

At any day in the fishing season all along the East and North rivers the string pieces of the wharves are alive with bare-legged hatless urchins, each with a piece of lobster for bait, and all engaged in tempting from the depths "tommies," eels or "nigger-fish."

The fish that will be described below are properly termed "panfish," and at the head of the list of such fish we would with propriety place the blackfish, or tantog. His firm flesh and frequently large size, and his disposition to resist capture almost equalling the bluefish, would perhaps permit of his being classified among the game fish of our shore waters, but as he will not take a surface lure that would perhaps be objected to by many.

A close and strictly scientific description of these pan-fish would not be necessary, so I will describe the fish of this paper from an angler's point of view.

The blackfish in color is of every shade of grey, often only marked. 
with greyish spots on a pervading black, and is alwars deeply black along the dorsal. For a fish not swift in his movements his extent of fin is great, especially noticeable in the dorsal and eandal ; the pectorals also are very large. The head is very big an 1 heary ; the back is ligh-arehed immediately behind the head. The eye is full and round, and the month is small and bordered by thick fleshy lips. There is a heary eoat of scales over the whole bouly, and they are remarkably hard to get off in clressing the fish. This difticulty can be partially done away with by dipping the fish in villexar before scaling him.

The blackfish runs in size from half a pound to tew or twelve younds, fish of the latter weight being taken in deep water. The season for tautog fishing commences in the last of April-fishermen say when the willows eommence to bul-and eontinues through the summer months, ending about the midnle of October.

The blackfish is a bottom fish; he loves the rock-strewn tidemays and the shelving sedgey edges of narrow channels. It was this preference of the tautog that made New Tork Harbor and its ap Froaches the greatest blackfishing grounds known to the angler.

The rocks of Iell Gate are renowned for their number, but only besause of the vast traftic which passes through that ehannel; they do mot exceed or even equal the myriad boulders which choke the two river arms to the north of it. Little Hell Gate is a a roaring Eorrent when the tide is running "up, and Bronx or Harlem Kills is its counterpart. This last was the most famous place of all for Wlackfishing.

Right in the middle of the water about two thirds of the length of the Ifills from the Harlem mouth, there is a vast round rock, one of those smooth topped boulders, relics of the glacier that hollowerl out the bed it left them in. At half tide the waters sweep loy this stone like a miniature Niagara and create a strong eddy behind it There cxisted in this rock a huge iron ring; no one ever knew how it got there-and in times gone by if the angler could get his "painter" tied to that ring at the first of the flood tide he was sure of as much sprort with the blackfish as he cared to enjoy. It is needLess to say to Harlem fishermen of tu-day that a blackfish is a rure 


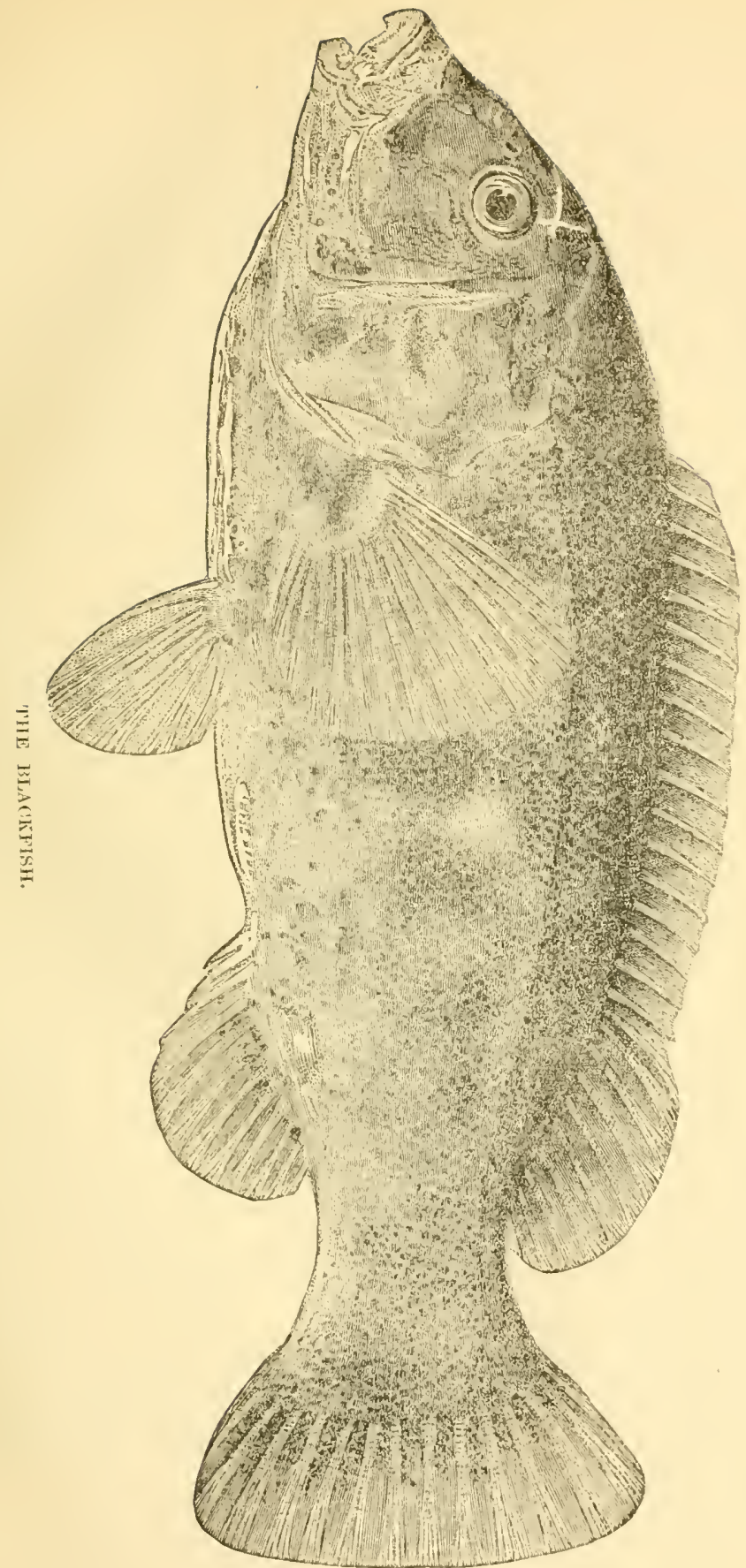



avis there in the rear 1883 . But the tautog has not altogether de. serted the lower Sound, and below I will give the names of some places where lie ean be taken.

The tackle for blackfishing does not differ materially from that for weakfishing, save that the hooks should be low in the point and of rather heary wire. The hook, when the sinker has reached bottom should then be drawn a foot or so up from the river bed. The best baits are the hard clam and the sand worm, and when the fish are plentiful the fiddler crab, placed entire on the hook.

A peculiar way of fishing which I have noticed along the Sound, is to have a pole twelve or fourteen feet long without joints-a "bean pole"-and no reel, but only a fixed length of line. The pole is elastic, and when the fish, having taken the bait, is wearied with his efforts to free himself, the pole is raised and the fish swung in to the fisherman's hand-a very primitive style of fishing, and one only suited to shallow water, not exceeding sixteen feet in depth. When a three or four pound blackfish strikes he makes three or four lunges to right and left, pulls back strongly, and sometimes when nearing the top moves in small circles. Those under a pound make very little resistance.

Blackfish 'an be taken at Barnegat, off Long Branch or Rockaway Beach in great numbers, and at Montauk Point; not being caught I believe above Martha's Vinesard.

The above are outside fishing spots, but Long Island Sound rivals them all. Among the many good places on the Sound, Pelham is the best. The village of Pelham is sitnated on a river and beautiful bay of that name, and is about ten miles from New York city. It can be easily reached from the metropolis by taking the New Haven train at the Harlem depot of the New York, New Haven and Hartford Railroad. The ride along the shore and through the rich farms of Westchester county is a delightful one, and if made in August or September is pretty sure to end in a successful day's fishing.

The flesh of the blaekfish is white and firm, and if cooked as described on page 226, vol, 1, of The Avgler, is one of the most tasteful of all the salt water fishes. 


\section{CHAPTEI X.}

\section{The Flounder-Plutesel vulgaris-Gill.}

When the angler's paper of America employs its artist to depict the form of the first eaught flounder of the summer run, and when it announces the results of bis labors two weeks ahead, then my bumble pen needs no excuse for treating of the flatfish in these essays, and I will grive none.

The flounder I fear-has been much looked down upon; it has been called ouprobriuus epithets, such as "nigger fish," but its broad back will bear all this abuse, and it will continue to emerge triumphant from the frying pan with its fail tmed np in a disdainful twist.

The flomeler has one virtue not possessed by its prouder relations; he is always ready to be eaught. Just as soon as it gets mild enongh for the hardiest fisherman, he has but to drop his hook over a soft mud-bank, ant when he raises lis line, lo! there is a flounder at the other end. And agrain, when the flounder makes up his deliberate mind to bite he does so in a thorongh manner, and when the angler pulls him out the flounder has by some peculiar internal mechanism. wurked the hook almost down to his tail (swallowed the hook, as the boys say), thus saving the fisherman that great vexation of spirit consequent on losing a noble fish.

Before this is in type every reader of The Axgler will have seen a faithful likeness of the flounder, so it is unnecessary for me to describe his shape. In color he varies, from an instance of one white 


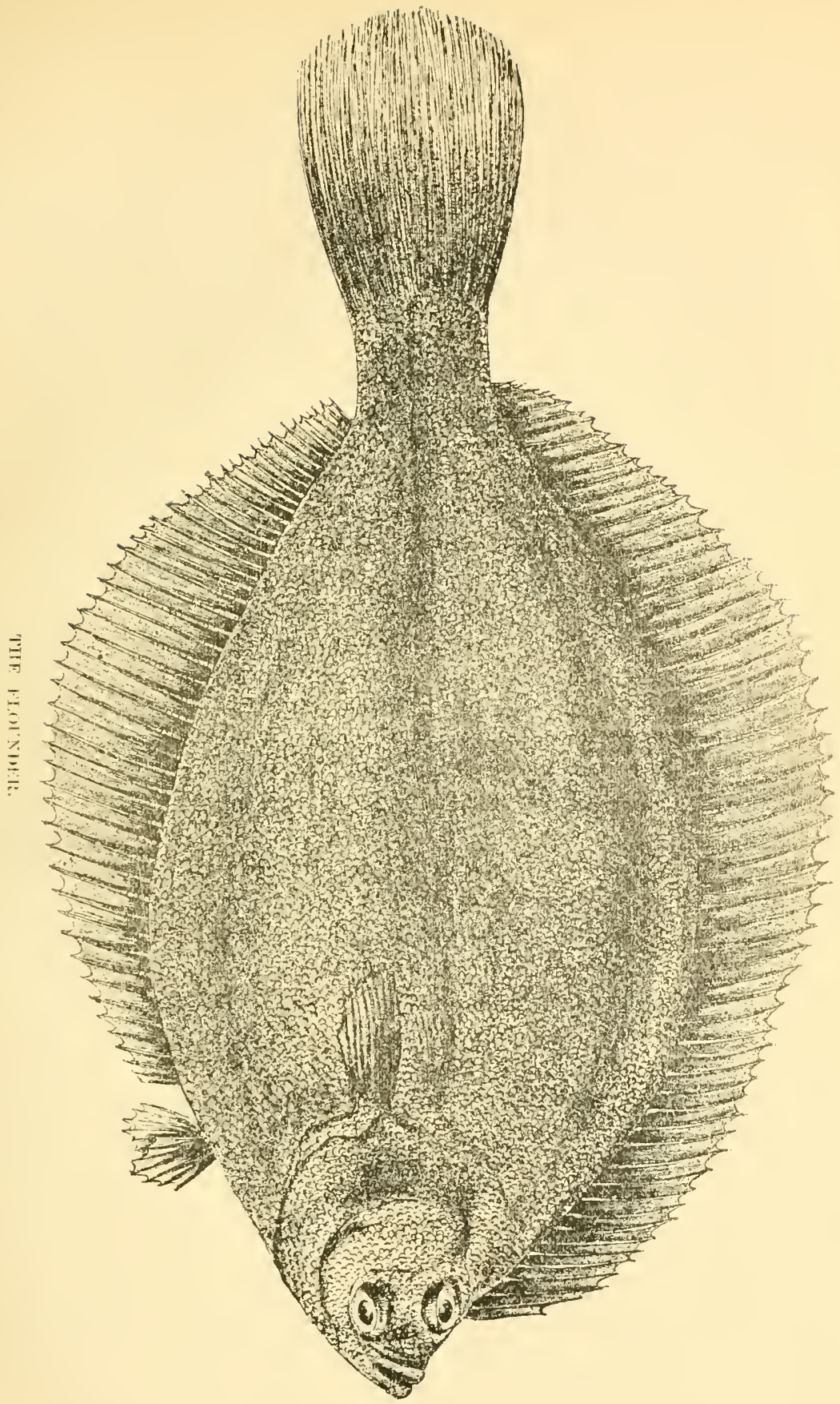



on both sides (one side is always white), through all shades of mottled brown.

The big fellows (known to many local fishermen as tide runners) are a deep, rich brown or black-frequently, like the blackfish, marked with spots of gray. Often the color changes after they are caught. The young ones and the smaller kinds are lighter in tint, when very small being translucent. I don't mean to say you could real a newspaper through them, but holding them up to the light you can see the arrangement of the bones and fins.

It is a curious physical fact that the young of the liounder, the fry, when first hatched are shaped like other fish, with an eye on each side of the head, but through a process of adaptation, as the fish matures the eye, strangely enough, slips around the head, and takes up its station permanently near the other. I have never seen this unone, but it is a fact.

The flounder is canght from April to November, and is in the best condition at the extremes of the season. They run of all weights. I have seen them that didn't weigh anything, (they were the translucent ones) and others that would make the index point to six pounds; these last being popularly termed flukes. If we count in the halibut, then say 250 prounds as their highest limit. The flounder has the habit of lying in the mud, being fitted for this by nature, and so well is his back simulated to his surroundings that it takes a pretty old crab to tell where the flounder ends and the mud begins.

The peculiarity of flounder fishing is, that you seldom know when you have a fish on. He nibbles softly at the bait, or very slowly sucks it in. In fishing for flounders let the sinker terminate the line; then above this rig on three or four mole hooks, small but strong. Let the lead find the bottom and every now and then lift it a foot or so. It is claimed that this mancurre makes the fish forget his usual calmness and dash at the bait. The best bait is sand worms, and the best tide during which to fish is the first of the tlood, just as it turns.

Flounders are a great deal misunderstood. People buy them "nine days old," and then find they are not good to eat; but 
take a fresh one right out of the water, and cook him as he should be cooked, and he will prove himself a fish not to be despised.

The best place to catch flounders is in general everywhere; in particular, Rockaway Beach, North River, Harlen River, Sands Point, Westchester Creek, Pelham and Berrian's Creek. 


\section{CHAPTER II.}

\section{The Sea Bass.-Centropristis atrarius-Linn.}

The sea bass, a coast fish that never exceeds three pounds, is rarely caught nowadays except in the ocean. It used to frequent the es. tuaries and bays about New York, but now is seldom seen there,* and when they are taken are very small, averaging about half a pound.

The sea bass has many different colors seattered over its body. The prevailing tint is blue and black-blue; the gills are a bright searlet and the inside of the mouth lined throughout with a brilliant yellow. The deep blue of the dorsal gradually merges into a lighter blue on the ventral region.

All along the coast these sea bass, like the kingfish, are getting scarcer and scarcer, whether as one of the results of the bluefish attacks I do not know. As I have said, they are rarely caught by New York fishermen; when I have taken them it has been at the end of the summer fishing in the coolish days of October and November.

The sea bass makes less resistance to eapture than any salt water fish I know of. Even the flounder will curl himself up until he becomes like an umbrella, coming up through the water wrong side up, but the sea bass allows himself to be drawn right along, and when once in the boat dies very quickly. One would expect from his great stretch of fins a stout fighter. The sea bass has a very large month and big eye, and a heavy coat of large scales covers his body.

Although generally small it sometimes reaches the weight of three pounds, and is caught of that size off Montank Point, Long 
Island. Thongh not a very prominent fish on the list of the salt water angler, Kilburn, the artist, has included a beautiful copy of him in his wonderful series of game fishes, and I would refer my readers to that work for a just idea of the glorious coloration of the salt water fishes.

The sea bass is a bottom fish, swimming about and living on the crustaceans that inhabit the rocky bed. So, in fishing for sea bass, the sinker should be kept not more than a foot above the bottom. The best bait is sandworms and clams, and the best tide is at the flood. The sea bass is not very good eating unless just from the salt water. Like the weakfish, if kept, it has a tendency to grow oft and insipid. 


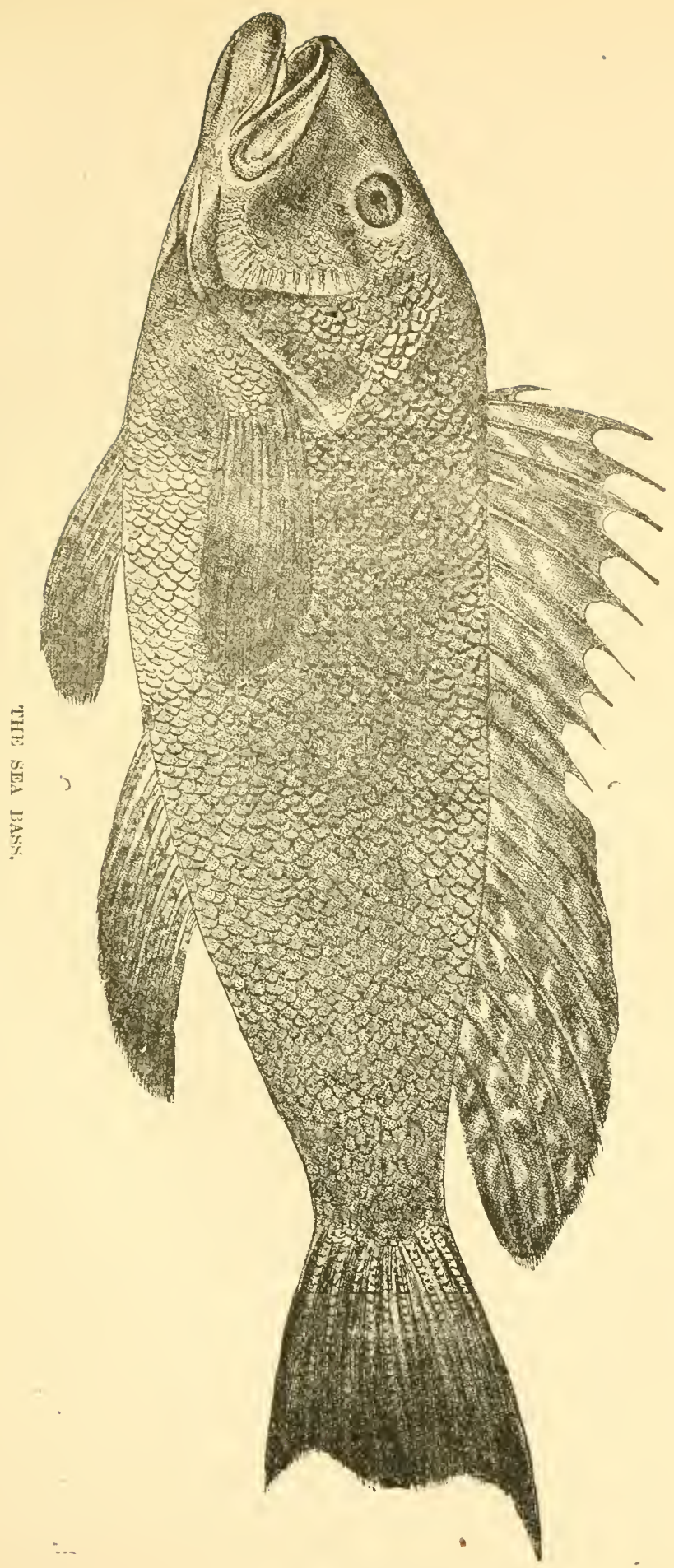





\section{CHAPTER XII.}

Tue Bergali-Tautogolabrus adspersus.

This fish has earned, and deservedly, much opprobrium on a good many accounts. It is a very small fish, only in very rare instances reaching a pound's weight. The general color is blueish on the dorsal, merging into a greenish hue beneath. Different sizes vary greatly in color. Some bergalls are brownish, some blue, some green; the largest have an orange tint about the gill covers. The eye is not large and the mouth, in which there is a plentiful supply of sharp teeth, is small and bordered with thick lips like the blackfish. In the dorsal fin are several very sharp spines likely to inflict a severe wound unless the angler is eareful.

The strong seales of this fish are almost impossible to take off if once allowed to dry. A dip in sharp vinegar will render the task of dressing the bergall easier. The bergall is a vicious looking little fish; has a mean face.

This fish is very plentiful about New York, and is eaught about rocks and sunken timbers. The bergall is an invariable co-dweller with the blackfish ; his great delight, and, indeed, it seems to be the ouly purpose in life, is to steal as much bait as he can swallow, and I am inelined to believe that when he is unable to eat any more he takes the bait off the hook in mere wantonness and throws it away.

I would advise all anglers who have eaught a lot of hergalls in their day's outing not to go to the trouble of taking them away and cooking them, unless of more than usual size. The best thing to do is to cut them up with the bait knife and throw them overboard (what fishermen call "baiting the spot"), thus serving as an attrac- 
tion to other and better fish. As a food fish the bergall is not very good, the small ones frequently being muddy.

I do not snjpose that anyone wonld think of going ont especially for bergalls, but if the fisherman really wants to catch the sly feilow, let him rig a "gang" of rery small hooks, laving a big bend and extremely sharp points; put on a microscopic liece of bait, and as soon as the line is down give it a sharle jerk upward. I lave often tried this mothorl with suceess. The hooks eatch everywinere, in the tail, the belly, on the lack and in the hear. The borgall bites eagerly at low tide. 


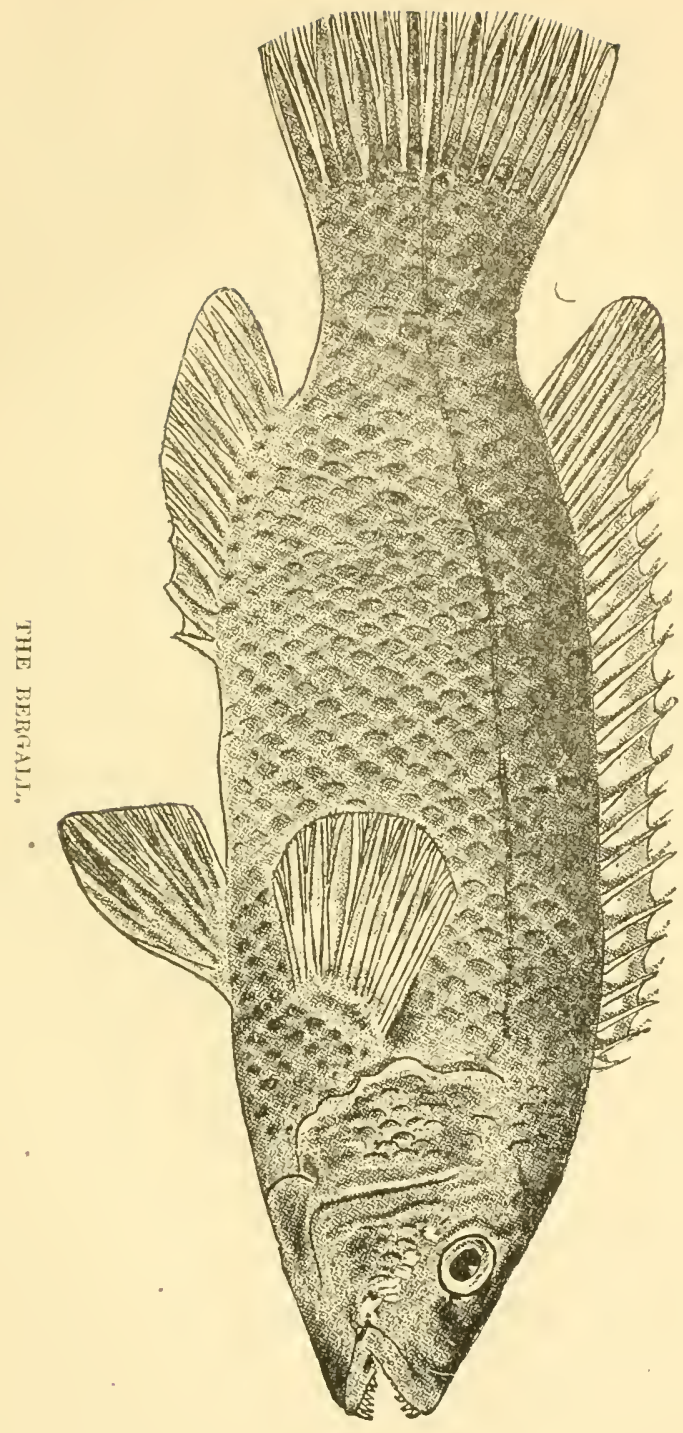





\section{CHAPTER XIII.}

The ToмcoD-Microgadus tomcodus-Gill.

The tomcod is a small fish, a member of the cod family, and is caught in large quantities about New York wharves in summer and fall. The tomcod seldom reaches a weight of half a pound, (?) attaining its maximum growth about the time of early frost. It is a lively little fish and gives great sport to the small anglers about the metropolis. It has the exact shape and form of the codfish, only in coloration and marking it is far handsomer. I have taken a tomcod from the clear waters of Harlem Kills in the month of September, which, when it was landed on the float at my feet, had a bright golden color with a tinge of red. The eye of the tomcod is prominent and reddish in color. The fins are large, excessively so considering the size of the fish, and are as soft as wet paper.

He is a gamier fish than his deep sea cousin, and if in large quantities gives great enjoyment. The largest "tommy" I ever caughtand it was the biggest one I ever saw-was about twelve inches long and weighed a little over half a pound. The tomcod is not such a bad fish to eat as some would suppose who had bought them from some fishmonger's stall where the ice had taken the flavor out of them days before. Like all soft-fleshed fishes the tomcod must be cooked and eaten immediately on taking it from the water.

The very large ones are not so good as the little ones, and when an unusual catch has been made and the fish dealers are anxious to dispose of the perishable stock, they give the tomcod other names, such as "frostfish" and "London trout," and often impose upon the 
unwary. They are totally different from "frostfish," these latter" being a very tasteful fish indeed. As for "London trout," that is a very good name to entrap countrymen with. The best time of the year to go fishing for "tomeods" is September, and I know of no better place than along the docks of the North River, from 110th street to Spuyten Duyvel.

The rig is the same as is used in flounder fishing, and it is luest to fish with a gang of hooks fastened above a hollow round sinker, which must be light. Sandworms are the best bait, and the ebb tide I have always found to be the most suceessful starge of the water. There used to be in Farlem Kills an old float and boathouse kept by "Sandy" Gibson, and from that float, which was anchored directly over the once famous striped bass spot, the "Willows," I enjoyed the most successful pan fishing I have ever had. It was a great plane for tomeods and flounders, and off of it I took the big tomood mentioned above. Tomoods will take the baited hook when they are no bigger than the little finger, and bite from early April to Decmber. The smaller they are the better they sre to eat. 


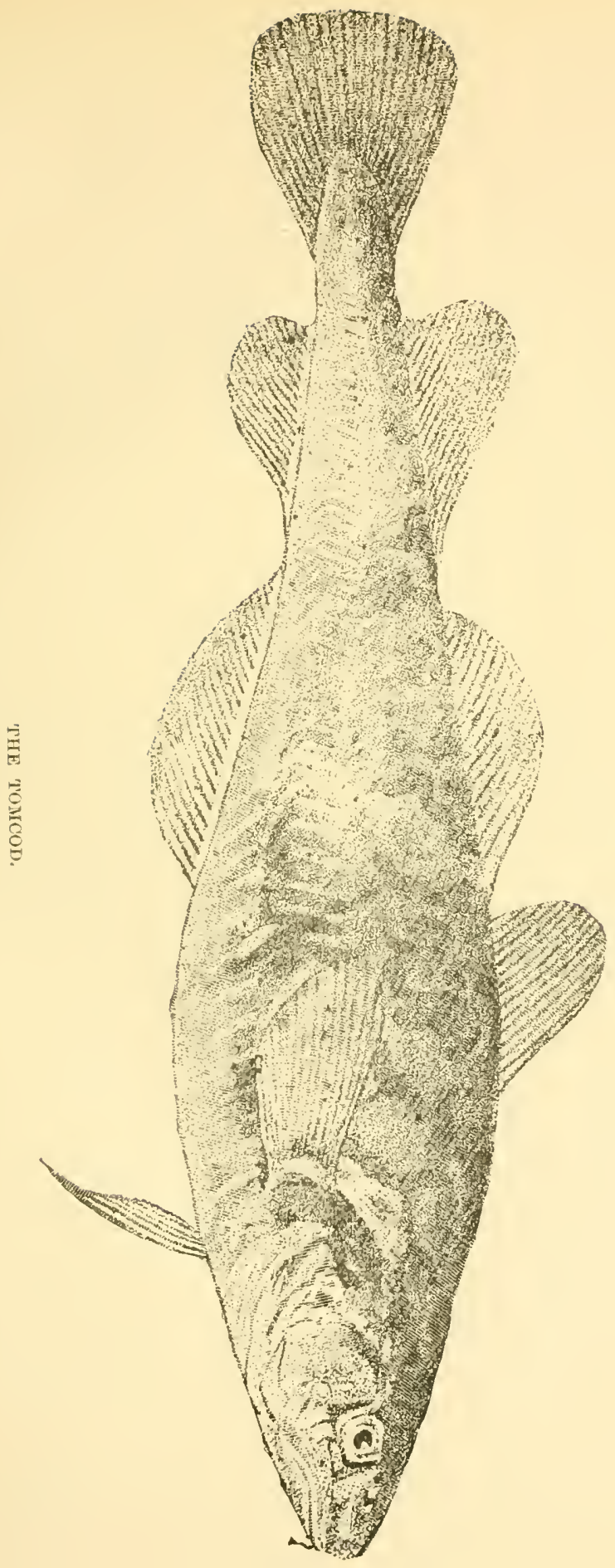





\section{CHAPTER XIY.}

\section{The Codfish.-Gadu: morrhua.-Linn.}

Does anyone who revels in black bass literature and б̆̃ook trou history wonder why, nay, indiguantly inquire, what business the "low-down" codfish has in such company? The New York City angler can tell him. What one of that noble fraternity has not gone to the "Cholera banks" after codfish, and what one of that aforesaid fraternity has ever canght one?

Though to fishermen who are joined to their idols in the shape of a six-ounce bamboo joss and a mystic brass wheel, quick-revolving, termed a reel, the codfish is the lowest of the low, yet it is the most important food fish, with the exception of the little herring, known to our age. Whole communities live by catching and selling the codfish, and the right of fishing for them in certain regions has been made a clanse in international treaties.

The codfish multiplies more rapidly than any other salt water fish, and lives on the small crustacea that inhabit the depths of the ocean. It is found in the salt waters of New York and New England States, but its home and stronghold is at the fog-shrouded banks of the Newfoundland. There they are caught by the thousands of tons, by means of set lines, consisting of hundreds of feet of line, having a hook at every interval of three feet, baited with small pieces of fish or clam. These lines, heavily leaded, are sunk in the ocean sup- 
ported by a float on the surface and are left out during the night, pulled in in the morning, baited again, and once more visited during the afternoon.

Then again there is dory fishing for codfish (the dory is a slim and long skiff, sharp at bow and stem, and as light on the waves as a cork). This is the most exciting and dangerous kind of fishing that can we indulged in. $\triangle$ fising smack starts for the "banks" and on reaching them anchors. Then such of the crew as may be chosen are sent out in dories with an allowance of water and a little something to eat. These hardy fishermen row away over the waves (each one of the great rollers rising higher than the total length of his light craft), and soon lose sight of the schooner. Reaching his appointed grounds each man anchors, bows on to the ocean swell, having an anchor at bow and stern. A moment in the trough of the sea would be instant destruction. Standing up in his tossing boat, with a line in both hands, surrounded by the shifting fogs and rhick mists, the toiling fisherman must give constant attention to the lines, straining his muscles with pulling in great halibut, haddock and codfish. The fog is close about him, when suddenly the vast, fantly ontlined form of a New lork-bound Cunarder passes within stonethrow of his dory, or the arr grows ehill by the nearing presence of some huge iceberg. Such is the life of the cod-fisher, and many are those whom the returning slool reports as "missing."

The New York angler knows colfishing in a different aspect; he sees a notice in his Sunday journal that the commodious, sumptuous, ete., etc., palace, etc., ete., steamboat will take a party of gentlemen to the "fishing banks" at such and such a time. Excursion ticket one dollar ; lines and bait furnished. Well, he goes; why not? After hearing a coarse cotton line and a pound or so of lead an hour or two, he turns from the fishing banks to the fishing bar, calls for a glass of - water, and comes home disgusted with things in general. The bait on these occasions is chopped fish or clams. The codfish, when hooked, makes two or three lunges and then comes up like a log. I have said too much about the codfish-he is an ugly gray fish in my opinion, good neither to eat nor to catch. In the fall along the Jersey coast codfish are sometimes taken by skittering with a piece of red flannel as a lure. 



\section{CHAPTER XV.}

The Haddocs-Morrha agleferius.-Gill.

This fish, though not properly an angler's fish, still for the same reasons as the codfish, ought to be included here. It is a big and heavy fish, with peculiar fins looking as if they had been trimmed. Its mouth has numerons teeth and its eyes are large. There is a strange story connected with the haddock. The tribute-takers of $\mathrm{Ca}$ pernaum demanded tribute of Simon 'Peter and the Lord. The apostle was told by the Lord:

"Go thon to the sea and cast an hook and take up the fish that first cometh up, and when thou hast opened his mouth, thou shalt find a piece of money, that take, and give unto them for me and thee."

The apostle did as he was directed, and canght, according to the tradition, a haddoek, and while taking she coin out of his mouth he grasped it between his finger and thumb, and to this day the haddock bears the marks of the impress of tine apostle's thumb and forefinger. They are two black marks abont the size of a threecent piece immediately behind the head, just where an angler to.day wonld grasp a fish to extract the hook from its jaws.

The haddoek has a distinet black line running along its sides; the same lateral line in the codtish is white. As regards coloration the harddock is darker than the codfish. It is a more tasty fish also, and is nsually smoked before being bronght to market. A celebrated kind of smoked haddock comes from seotland and th $y$ are known as "finnan haddies." The haddock is canght pruncipally in winter 
by professional tishermen in the neighborhood of Cape Cod, though the extent coastwise of the haddock run, is from Delaware Bay up to northern IIaine. The baits used are chopped herrings and sometimes salted menhaden. 


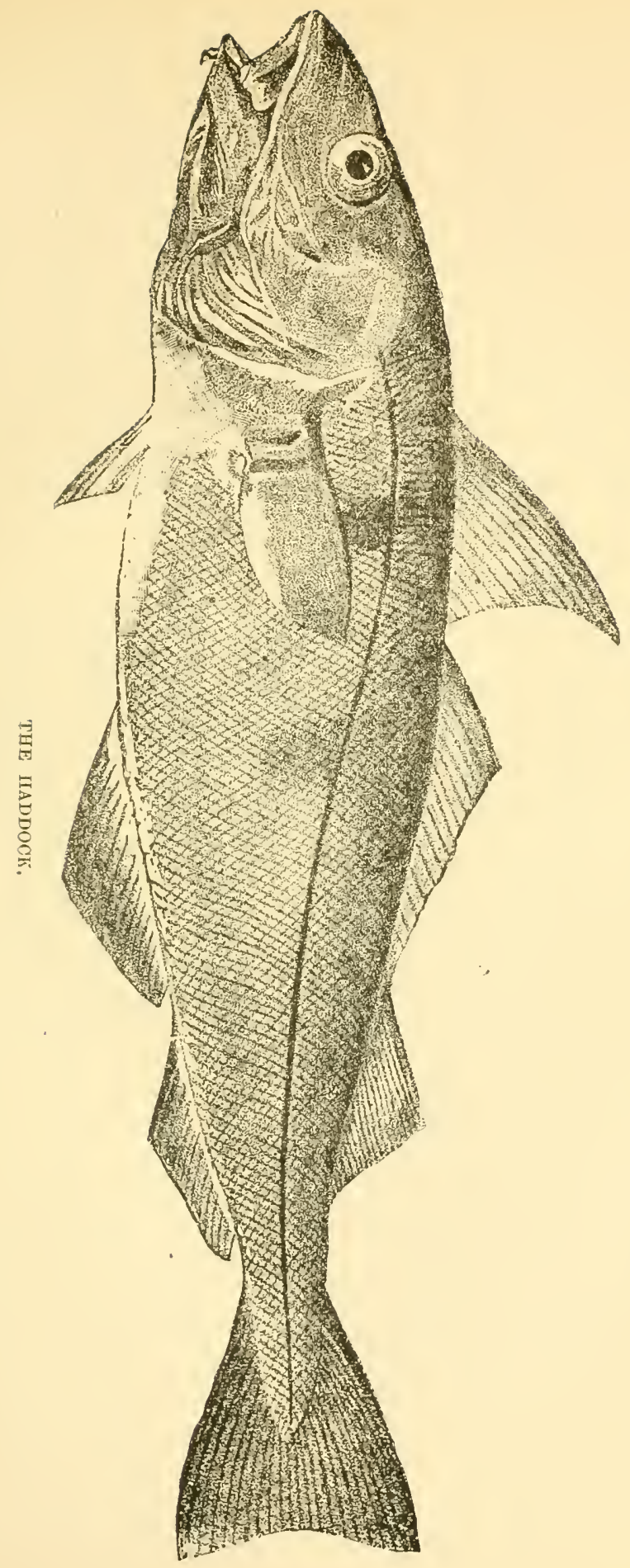





\section{CHAPTER XVI.}

T'ue Menhaden-Alosu menhaden-(Gill.)

This seemingly worthless fish is one of the most important of all the salt water fishes. There is not one of us, be he a fisherman or not, who is not interested in the mossbunker. They swarm all along the coast, even some distance up the rivers every summer, and upon the regularity and perpetuity of that migration depends to a great extent the fish supply of the Eastern Coast cities. The magnet that draws the great armies of bluefish to our waters is the vast shoals of menhaden that preeede them. The best bait for striped bass in surf-fishing, and, in fact, the material of all chumming, is the mossbunker. I have seen great eollections of these menhaden ascending the Sound, and next day following a school of porpoises, rolling, tossing and diving in merry style through the water.

The great use the menhaden are put to is in making fish oil, and right here lies a very threatening danger to our eoast fishing. Soine nets are made that cover acres, fast-sailing steam tugs scour the shoal waters of the coast at all times and seasons, and with one haul of the nets, worked by huge engines, countless thousands of the defenceless menhaden are taken. The fish are then either ground up and subjected to the process of rendering for oil or are sold to the shore farmers for manure. There are fleets of these steam tugs sent out by rich corporations, not to speak of smaller and less amnitious vessels. In this way, in season and out of season, thousands xpon thousands of the most important bait fish that swins are ruth. 
essly slaughtered to serve the pleasure and avarice of greedy capialists among whom it would be safe to bet there is not one angler.

As a result of this system of wholesale depletion the mossbunker is steadily decreasing and threatens to become scarce and finally to become extinct. If this shonld ever happen there would be an inmediate falling off in our fish supply, and, unless the hand of Providence interposed, a total failure of it. But there is no reason why the capture of menhaden should be stopped altogether, but there is every reason why the menhaden fishermen shonld limit their destructive trade to certain periods. To secure this it behooves the Assemblies of the States bordering the Atlantic to pass an act limiting the catching of menladen with seine nets to an open season and have the rest of the year close. This would allow the menhaden time to multiply and would secure the future of the fish markets.

In form the menhaden resembles the shad, It has the same shape and contom of body. It is a bright silvery fish, and so far as I know, has never been taken with a hook. One of the most useful purposes the menhaden serve is in the lobster fisheries; the fish are salted before beirg used for bait. The menhaden are almost all of one size-abont twelve inches long. The farmers of Long Island sometimes eat the mossbunker. It has an oily, rather rancid and "fishy" taste.

It is necessary that every angler should use his best influence to secure some protection for the menhaden, else they will become ex. tinct and with them a great branch of salt water fishing. 


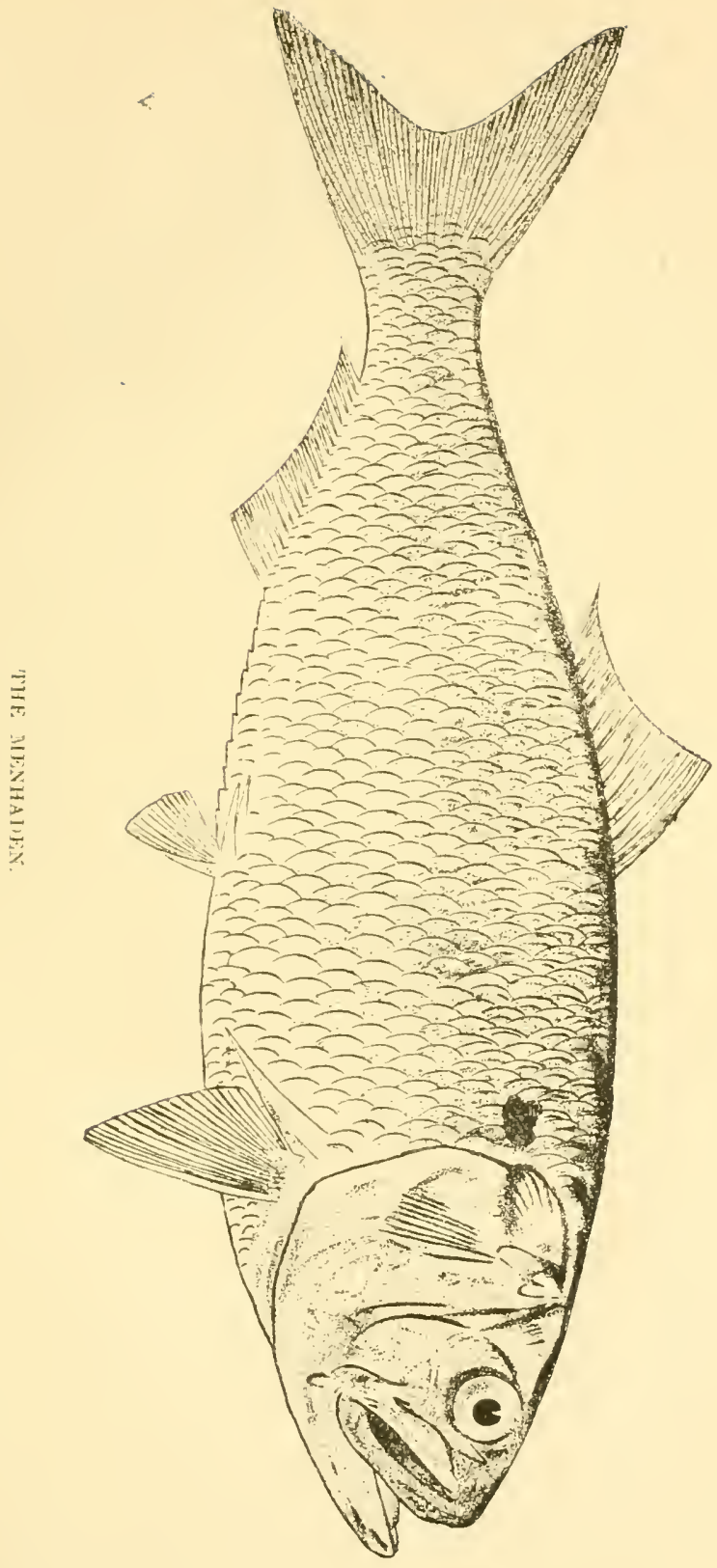






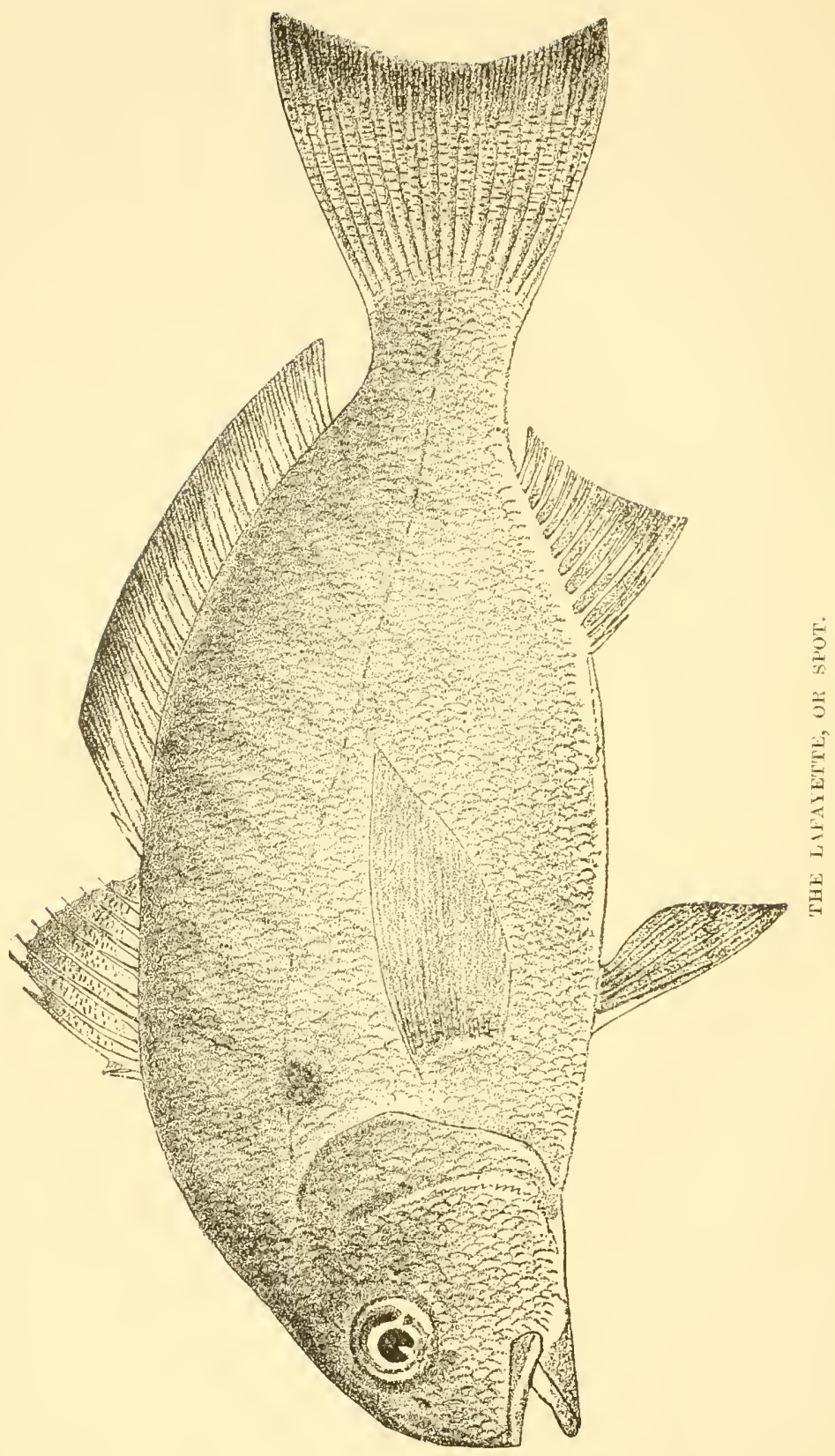




\section{CHAPTER IVII.}

The Lafayette, or Spot-Licitomus obliquus.

This fish is said to have first made its appearance in any numbers oul our coast simultaneonsly with General Lafayette in the year $1 \& 81$, and from that fact it has taken its most popular name. It is a very small silvery fish with a big spot on the back, and it seldom reaches a weight of eight ounces. It swarms on the eastern coast during the hot months of July and August, and is canght even in Septembe!

In the Harlem and East Rivers and in Long Island Sonnd, where I have caught them, they run very small indeed and it requires great patience and small hooks to take them in. They keep up a constant nibbling and the angler is so busy pulling his line up every minute or two that he wishes he had not fallen in with the silvery pests.

Like the bergall the "spot" bites at the hook with a sly tentative nibble and immediately darts away, as is proved by their being frequently hooked in the back, sides or tail. But there is this difference between cmmers and Lafayettes; the latter are good to eat and the former are worthless. I know of no daintier morsel than a big fresh Lafayette, nicely fried and served hot. They are the most tasteful of all the salt water pan-fish with the exception of the Stonington eel.

Few would care to go out especially for spots, but if you do, have a lot of fine, shary hooks, put four on your line above a light sinker bait with small pieces of clam or sandworm, and fish on the first of the flood or at dead high water in about fourteen feet. It is great fun to take them with a very light rod. They can be caught in great numbers at Rockaway, Cape May, Atlantic City, in fact, everywhere on the coast. 


\section{CHAPTER IVIII.}

-The Sxapplag Mackeled-Gemis temmodon-(De Kay.)

The snapping mackerel is a small rakish looking fish, swift in his morements as an arrow, darting about in schools, near and sometimes on the surface of the water. It is claimed by some that they are the young of the bluefish, and though this assumption seems substantiated by the shape, color and habits of the "suapper," ret I do not believe it is an established fact.

In form, the snapping mackerel is, long; tapering and trin, much like the blnefish in shape and disposition of his fins. The ere is quite large and the mouth armed with teeth. In color it presents erery shade of metallic blue, deeper on the dorsal, lightening to frosted silver on the rentral.

The snapper makes lis appearance in August and does not take any lure after September. The fish gives great fun to the angler and affords considerable room for skill. He can be taken only in still water, and I have nerer canght one in a tide-way. At the top of the tide is the time, giving, may be, two hours fishing, during which a hundred or more can be landed if there are many snappers about.

A light and flexible rod is required, a very smooth rumming reel, and thin line and swivel sinker. The hook, which may be quite large, is fastened to about a foot of gut and baited with shedder crab, or if it is found that this is rasted too rapidly, any bait lure 
is just as serviceable. The leader is cast out about forty feet, and while the bait is kept about three feet below the surface is rapidly reeled in. The smapper makes a dash, and is caught and reeled in as fast as possible.

The snapper very frequently escapes by his quick movements, often jumping the hook. Although a small fish, rarely exceeding a pound, he resists stoutly and comes toward the boat with a sort of flurry and splash rery exhilarating to the fisherman. I have alway taken them most successfully on bright, clear dars, and only on the last two hours of the flood ticle. It is a strange fact that muder the operculum of ahnost every snapper is found a fish louse, generally half an inch long: I have nover seen them $m$ any other fish save the small striped bass. Besides being so gany and exciting a fish to catch, the snapping mackerel is rery palatalule. 


\section{CHAPTER XIX.}

THe SHAD-Alisa sapidissima-(Wilson-Storer.)

The fisls this paper treats of make's up the tail end of the amateur angler's list, and yet the capture of the first shad in the North River is heralded in all the Metropolitan joumals. The fish itself is received in Fulton market by a deputation of citizens, then decorated with ribbons and hung up to the ahniring gaze of hundreds.

The shad does not, however, possess the sanne interest for the fisherinan as does the mossbunker.

The shad is found all along the Atlantic Coast from Florida to Newport; in fact the fish is seen all over the world; in European rivers and in China waters.

The migration of shad commences in Spring at the Florida coast, and as the fish move northward they increase in size and in flavor. Those which first reach the New York market come from the shores of the Carolinas. The first North River shad was canght and taken to Fulton market April 10. From that date onward to Jnly 1st the fish are taken by thousands and get to be very cheap. At the close of the run Comecticut River shal are bronght in and bring fancy prices, as they have a far more delicate flavor than those called Southern shad.

The shad run in from the ocean up to fresh water to deposit their spawn, and advantage is taken of this great movement to take them in huge nets set across the current. Seine nets, stake nets, drift nets, 


$$
2
$$



and pound nets are all used successfully at the mouth of the Delaware, at the Potomac Falls, in the Hudson, and at the mouth of the Connecticut River.

In appearaice the shad is a heavy and broad fish, with rather small head and mouth, large eyes, forked tail and small fin development. His body is covered with a heavy coat of large seales rather loosely held on, and when he is first drawn from the water his sealy armor is resplendent with every tint, but this beautiful coloring soon fades.

But the chief wonder about the fish only comes to light when you eat him It is his prodigious amount of bones. Some one once said that if all the bones of a six pound shad were placed end to end in a continuous straight line they would go twice around the world, and if they were piled up in a heap, it would form a pyramid two feet taller than the pyramid of Cheops. But it is very apparent that these statements are largely exaggerations, evidently indueed by a sharp attack of bone in the throat. Still the shad has more bones in comparison with equal weight of other fish than any four other salt water fish taken together. Shad is one of the many favorite dishes of the bluefish, and it has always been a standing marrel to me how the bluefish could eat him and not choke to death.

,The interest that the shad has for anglers lies in the fact that he is a surface biter, and will take the artificiai fly. Fishermen who have caught the shad in this way name the following flies as the most successful: a white miller, a red fly with red wings, a searlet fly with mottled-brown wings. The hooks used are numbers one, two or three, Limerick. The rod and reel are the same as are used in striped bass fishing of the lighter variety. This applies, of course, also to the line, which should be a least one hundred feet in length. The best fly-fishing for shad can be enjoyed on the Comnecticut River in early June. It is the correct thing to cast the lures in some deep and silent pool at the base of a rapid, or in the rapids themselves.

The shad run in weight from two to twelve pounds, the average being about four pounds. As I write this at the beginning of the shad run, I learn that they are drawing a seine net every morning in 
the North River at the foot of 125th street. As it is done at three in the morning I have not verified the report, but there is little doubt that it is true.

There is a celebrated method of cooking the shad which I will mention here. This dish is known everywhere as "planked shad." A large fish is taken and split along the belly from head to tail, it is then fastened with the meat side outward to a smooth oak plank and slowly roasted before an open coal fire. It is then, when nicely cooked (and right here lies the delicacy and success of the operation) served up with lemon, on a hot dish, having been previously buttered and seasoned. The great place for the "planked shad" used to be Gloucester. Island in the Delaware River, nearly opposite Philadelphia.

Enthusissm in fly-fishing for shad has to a great extent died out, principally because where it can be enjoyed, striped bass, the monarch of the salt waters, are also to be caught, and again because the shad is not very gamy; not as gamy as you might expect from his bones.

In closing this essay on salt water fishes of the North Eastern Coast, the writer cannot have been free from error and omission in such a brief notice of so many fish. But I trust that all matters of interest to anglers, and such little information as lays in my power to give that may assist any of the angling brotherhood, have been at least clearly set forth. Of course it would be impossible for any one man to have a wide and accurate knowledge of every salt water coast fish, or even of the game fishes, and wherever my own acquairsance with the facts has been small or wanting, I have not hesitated to seek the standard authorities for verification, or to draw from tipecolumns of The American Angler, such new points as were a ince interesting and authentic. I do not lay down my pen without asking both the indulgence and kindly criticism of salt water anglere. 


\section{CHAPTER XX.}

\section{THE CRAB AND THE LOBSTER.}

Tue Crab-Calinectus hastatus-(Ordway.)

In the months of June, July, August and September, along the Southern coast in early summer, later in the Delaware and on the Jersey coast, and toward the close of summer in Long Island Sound, in the upper bay and its estuaries, and along the New England coast the crab advances from deep water in vast numbers. I do not hesitate to assert that in the crab season there are three crabs caught for every fish brought to market. In New Jersey, on the banks of the Shrewsbury River, there is an immense crab farm whence thousands are shipped to the markets of New York and Philadelphia. The little creeks and streams that run in Long Island Sound make the body of water a perfect paradise for the pugnacious crab. But of all places to catch crabs the best is in the Harlem River, and in New Jersey, Salem Creek.

The reason why the crab is included in these essays is that every salt-water angler goes crabbing, and if he goes once he will go again. Even people who do not care for fishing proper will go crabbing, probably because they think the yield is paying them for their time. Yes, the crab is a game "fish," but, strange to say, his fighting qualities do not assert themselves until he is in the basket, or just before you put him in. In fact, he is so game that I have seen ablue crab seize a finger of some incautious angler and then jump out into the water forty feet away. This occurrence, which by the way is not very uncommon, took so little time that it is now 
impossible to say whether the crab yelled and jumped himself, or whether the angler uttered the Indian war whoop and threw the crab. The latter is the most probable.

Crabs begin to swarm into the shallow bays and creeks of the coast about the first of June. When they have reached their summer home they all remain quiet for a space. Then each crab selects some spot best suited to his taste and becomes motionless, and soon bis upper shell shows signs of swelling about its back edge. After a time this edge becomes wholly freed, and now the crab must free his claws and legs from the hard shell. This he is enabled to do by an opportune softening of the muscles. The crab withdrawing from his shell settles down in the soft mud or sand and does its best to escape observation, for it is now in a helpless condition. Where there is a great deal of eel-grass and sea-cabbage, as in the Harlem River, the crab will cover himself in it and it will take a practiced searcher to spy out his retreat. Along the Harlem mud flats at low tide the boys go "treading for soft shells," and generally get more cuts on their fect from old bottles and tomato-cans. than soft shell crabs; though a dozen are often taken in this way on one tide. Abont twelve hours after it has cast its shell the soft skin with which it was first covered has become like writing paper, crackling like it when compressed.

Twelve hours or so after, this skin has become like buckram in texture, and on acconnt of this the crab is called a "buckram," as before it was called a "paper" crab. In all those stages the crab is helpless, but after the lapse of forty-eight hours he is again able to take care of himself.

The above are approximately the periods in which this strange transformation takes place, but it is dependent to a certain extent upon the weather. A disagreeable spell will retard it for days. The best of all crabs to eat are the soft shells; they are fried in butter, having been previously rolled in cracker crumbs.

Now as to catching the wary fellows. This is best done in shallow water not over ten feet in depth, and from a skiff. A roundbottomed boat on a crabbing expedition will only prove an inconvenience. Have abont a half dozen lengths of cord not more than. 
fifteen feet long and tie one end of each about some pieces of lean raeat; let this sink to the bottom, if it will not sink put on a lead sinker or any other heavy thing that is handy. When the bait has found bottom you will know when a crab has taken the bait by the straightening out of the line. Now hanl up the bait slowly and evenly; the gluttonous erab will still cling to it, and just when you can see the bait dimly through the water and the crab waving his. claws about it, lower the scap net from one side, gradually working it under the crab. As soon as he sees you he will let go, but if the man with the scap net is quick and steady the crab will go into the net every time.

The best bait of all is a sheepshead with the skin taken off, and to secure one you will have to speak beforehand to your butcher. The next best bait is meat without any fat, else you will have trouble sinking it, and when you are nuble to get pither of these baits fish heads make an excellent substitute. The bigger your hand-net the better for use ; have the handle not over five feet long for boat fishing. Paint net and all sea-green. The best stage of the tide to eatch erabs is while the water is rising. At the first of the flood th crabs come in on the flats from the channels. As the season draws to a close the crabs improve in flavor.

Even if the angler is indifferent on the sulject of crab-fishing, what would be do if he had not that bait of all baits, the sheddercrab, by which is known the crab just ready to east his shell. You can readily detect a shedder-crab among a lot of hard fellows by pinching the under side of the two side joints. If these are very weak and break easily, you can take off all the shell and find a thin blue skin underneath it. I advise every one who can to go crabbing, it is great fun, and if the crabs are plentiful you are apt to catch more than you can carry home.

\section{The Lonster-Homarus umericunus-(Edwards.)}

Are you surprised, indulgent reader of the angler's craft? Well, I don't wonder that you are. Faith! I would be myself if I were yon. You have read of the peaceful crab and how he is caughtbut the lobster, among the game fishes of the coast! what next? As 
for being a catchable inhabitant of New York water and all the way northyard, that he is. Few New York angler's know that within thirty minutes ride from their offices they can have delightful sport lobster fishing. But from Port Morris all along the beautiful shores of Long Island Sound, in the quiet little coves and bays that indent its cither shore, lobsters can be caught in season by the following method:

You first want a sound, trustworthy skiff, next two anchors, one for the bow and one for the stern. The most important thing is the lobster net. This should be made of stout linen cord; the ring of quarter inch wrought iron six feet in circumference. This ring will cost, if you go to some friendly blacksmith, about twenty five cents; to this ring the cord should be netted until the net is two and one half feet deep. These nets are very expensive if bought in a tackle store, but the fisherman if he takes real pleasure in his art will net his own lobster net; it will cost him then about a dollar and a half. The next thing is the bait. This consists of two salted menhaden (another exemplification of the manifold uses of that fish) which you can buy of some fisherman on shore, either for love, or, that failing, for five cents apiece. Tie across the net a string diameter; tie to this central string the two mossbunkers; now put about ten pounds of stone in the bottom of the net; this don't weigh much when in the water, and is necessary to take the net down. Now have about one hundred and fifty feet of light strong rope ; fix this to the net in the same manner in which the small boy ties his kite -tring to the "belly-band" of the kite. Go out where you see lobster pot floats (be careful to keep out of range of the professional lobster fisherman who owns them), at the first of the flood or at the last two hours of high tide, let down your net in ninety or a hundred feet of water, and while you wait to haul up the net, cut half a dozen little wooden pegs, about an inch long, and put them in a convenient place.

After the lapse of ten or fifteen minutes haul up the net; if it has a lobster in it it will be a heavy job, and if it has not it will also be a heavy job. Suppose you have one; bringing the net over the boat take the bottom of the net and turn lobster and all out on the 
bottom of the boat. There must be two on a lobster-catching trip, for this reason : the lobster immediately on being released from the folds of the net rises on his tail, waves his massive claws in the air and makes a vicious attack on the nearest man. He must coolly await it, and just when the lobster is going to seize his leg quietly put a foot on each elaw. Hold the lobster prisoner thus while your as. sistant takes a wooden peg and drives it behind the socket of the claw, thus rendering this formidable weapon harmless; let him fasten the other claw in the same way and now the lobster can do no harm; by this time the net ought to be pulled up again. Where there are lobsters this sport is exeiting and very profitable.

I rememier one such trip I made in August years ago with a neighbor. We went out from Port Morris in a little red skiff, the the bottom of which had been worn completely through by the rubbing of the heel against the stretchers. Through these holes the clear water of the Sound bubbled up like a gushing spring, and we had for bailer a eigar box lid. In the intervals of bailing we kept a lookout for the boatman on shore, who was known to be the possessor of a long range shot gun, and he would have used it if he had known we were lobster fishing near his pots. Well, we caught three lobsters and lost both anchor ropes. The lobsters made up for it, however, as one of them weighed six pounds and a half, the largest one I ever saw. One of the others weighed four and a half pounds and the other two; so this was not a bad seore. It could not be duplieated to-day, however, in the same waters, as the infernal blasting over the supposed wreck of the "Hussar" has settled all the Port Morris fishing. But at Pelham and from there up to Maine, lobster fishing ean be had in profusion. There is only one more thing to be said, and that is to caution lest the heavy net pulls the fisherman overboard, and moreover, put all lobsters under ten and one half inches long baek in their element as the law directs. 



\title{
THE FISHES 0F THE EAST FLORIDA COAST.
}

\author{
BY S. C. CLARKE.
}

\section{CHAPTER I.}

The coasts of the peninsula of Florida afford a great variety of species of fish, and probably a greater variety of valuable food fishes than can be found in any one region in the United States.

We find some migratory species that are common on the Northern coast, such as the striped bass, sea bass, bluefish, sheepshead, weakfish. There are others whose range is not usually farther North than the capes of Delaware; as the black and red drum. Others, which are local and stationary in their habits; such as the groupers. and snappers. And others again, of a more tropical character, which only appear on the Florida coast in warm weather, and whose home is in more southern latitudes; as the tarpum, cavalli and ladyfish.

These species are abundant in their season, and many of them are of the best quality on the table; for instance, the pompano, which takes its place among the three best fishes of the American Continent; the other two being, in my judgment, the salmon of the East coast and the whitefish of the great lakes. Tastes. differ, and some may dissent from this opinion, but having eaten of these fish on the shores of their native waters, I give this as my verdict.

Nowhere in our broad country can the angler find greater variety of game, or more or better sport than on the coasts of Florida. In 
an experience of more than fifty years as an angler, reaching from Canada to Florida and from Massachusetts to Colorado, the writer has found no region where fish were so abundant as on this coast. This abundance has existed from the earliest period in which Florida was known to Europeans.

Jean Ribault entered the St. Johns River on the flrst of May, 1562, and on that account called it "The River of May." He writes: "We found it as we went, to still increase in depth and largenesse, boyling and roaring through the multitudes of all kinds of fish."

Again : "It is a country full of havens, rivers and islands, of such fruitfulness as cannot by tongue be expressed, and so many sortes of fishes that ye may take them without net or angle so many as ye will ; also great abundance of pearls, which they take out of oysters, whereof is taken along the river side and on the marshes, in so marvelous abundance as is scant credible."

The fish and oysters remain to this day, but the pearls are not abundant.

Among the natural productions of Florida, Ribault mentions the orange; this is worth recording, as most modern writers assert that this tree was introduced by the Spaniards. It was probably the wild orange that these voyagers found, as vast groves of the bitter and sour varieties formerly covered thousands of acres of the peninsula, much of which have been removed. It was appropriate that in this favored land the sour orange should be placed near the fish ar d oysters, for which its juice affords the proper sauce.

Captain Bernard Romans, an engineer officer, who was employed by the British Government during their occupation of Florida, 1765-80, in surveying this coast, in his "Concise Natural History of Florida," New York, 1775, thus writes of the fisheries :

"The whole of the west coast of East Florida is covered with fishermen's huts and Hakes; these are built by the Spanish fisnermen from Havana, who come annually to this coast to the number of thirty sail, and one or two visit Rio d'Ais, or Indian River, and other places on the east coast. The principal fish here, of which the Spaniards make up their cargoes, is the red drum, called in East Florida a bass They also salt a quantity of fish which they call 


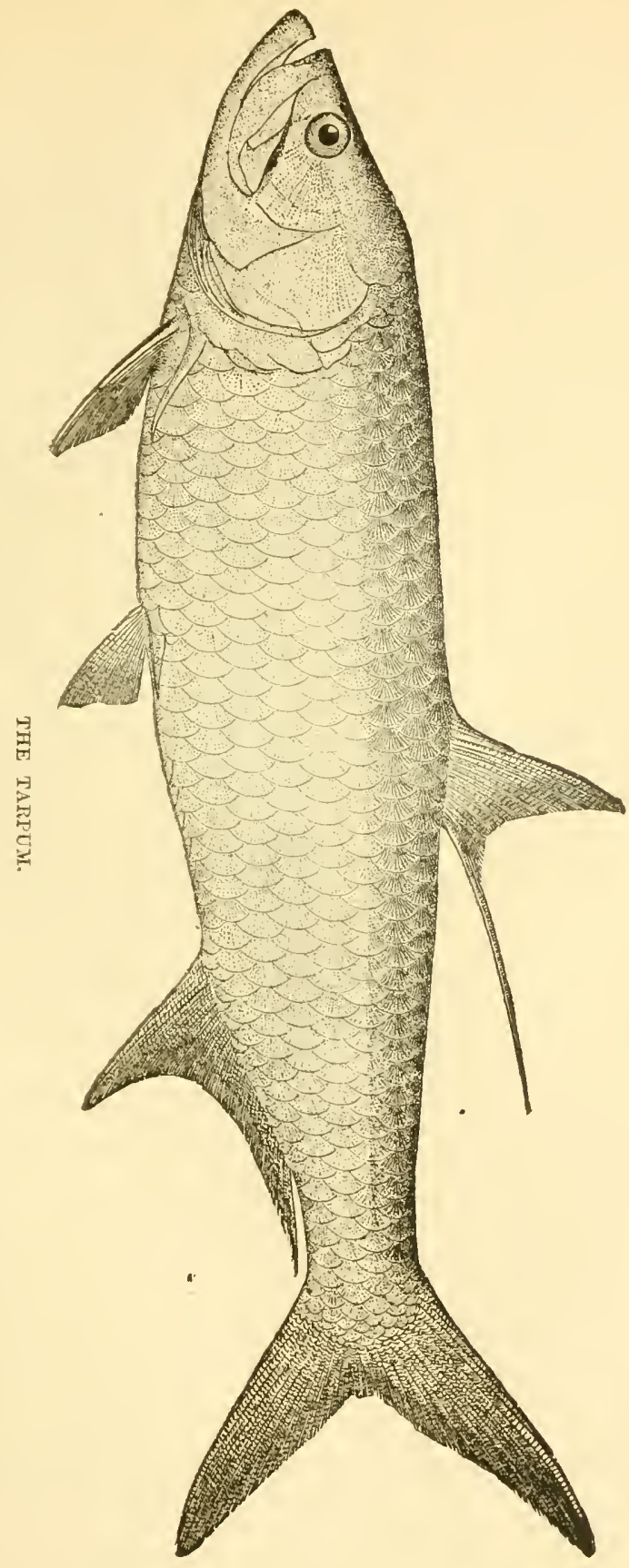



pompanos, for which they get a price three times as high as for other fish. A few soles, sea trout, and the roe of mullet and black drum make up the remainder of their cargoes. These roes are dried and smoked, and used instead of caviare by the Spaniards, who are very fond of them."

It may be added that these mullet rocs are still prepared for sale on the east coast, being much used by the Spaniards and Minorcans of St. Augustine. My host at Halifax Inlet, B. C. Pacetti, prepares many of them every summer, and I have found them to be a savory relish for my lunch when out fishing.

Captain Komans says of the Indian River:

"It abounds so mucn in fish, that a person may sit on the bank and stick them with a knife or sharp stick, as they swim by. i have frequently shot from four to twelve mullets at one shot; nay, our boys used to go alongside the vessel in the boat and kill the catfish with a hatchet. In St. Augustine the fishermen used to allow people

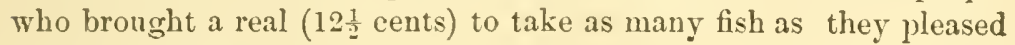
out of the boats."

Romans has the peculiarity of using the small letter i, to express the personal pronoum. We give the following list of the fishes of the Florida coasts :

"Kingfish, barracouta, tarpom, bonito, cavallos, pompanos, silverfish, jewfish, rockfish, groupers, porgys, red, gray and black snappers, grunts, mangrove snappers, logfish, angelfish, morgatefish, dog-snappers, yellowtails, muttonfish, mullets, murray, parrotfish, sproats, red and black?drum, bonefish, sharks, stingrays, and an immense variety of others, all excellent in their kinds, and we may with safety eat of of all fish caught on the Florida shore, unless it be hogfish taken on the outer reef, for $\mathrm{i}$ have heard of one of this kind having sickened some people; but i have always eaten that delicate fish with safety."

With the west, or gulf coast of Florida I am unacquainted; but I Lave passed two or three months of twelve winters on the south-east coast, and have been out fishing in my boat nearly every day in company with one of the oldest and best fishermen of that region, Mr. B. C. Pacetti, some of whose knowledge I may have picked up. In my first season I used a hand-line, like the natives, but soon aban- 
doned it for the rod and reel, which if it does not take more fish, certainly affords more sport.

Having no market near Mosquito Inlet, where I lived, we never cared to take more fish than could be used in one family. If we did, they were fed to the dogs, pigs or poultry, all of which live principally on sea food. So to use sheepshead, a fish which brings from twenty-five to fifty cents per pound in New York, seemed at first wasteful; but ar the Inlet they are so abundant un ther season that from fifty to one hundred might be killed in a day by a single line, if the fisherman seriously sets himself at work and was fishing "for count."

Fish of most kinds being most abundant near the shore where the bottom is covered with snags and roots of the mangrove, the hooks often get fast and are lost. In many places the bottom is paved with oyster shells, which cut off a fine line. Therefore silkworm gut is not suited for this fishing, nor is it necessary for these bold biting fish. Sharks eut off many lines, and rays break them, so that a line of 100 yards long is generally used up in one season.

We lose five or six hooks daily, on an average, and some sinkers. For red bass, salt water trout, groupers, snappers, and cavalli, I use New York bass hooks, Nos. I and 2. For sheepshead, the Vir. ginia pattern, No8. 6 and 7 answers best, being made of thick wire which resists the powerful jaws of that fish-the same hook for the arum. For small fish, such as blaskfish, whiting, pigfish, etc., I use the Virginia hook Nos. 6 and 7 , which are strong enough to hold a good sized bass. As the numbers and sizes of hooks vary, I remark that these figures are taken from the catalogine of a fishing tackle house in New York.

A Cuttyhunk linen line, 15-thread, 300 feet long, will hold and kill most of the fish encountered on this coast. Of course a 500 ponnd jewfish, a tarpum six feet long, or a ray six feet across, wil get away with the tackle. Reel, a multiplyer, of brass or German silver, to hold 100 yards, provided with a drag to increase resistance. Thamb stalls of heavy knitted yarn are neceseary, to save cut and brnised fingers in a fight with a rwoway fisb.

I find that a bamboo rod eight and a-balf to nine feet long, in three, or better in two piecet, will stand the hard work of three or 
four winters in Florida; it is light and handy, costs only four or five dollars, and will last as long and kill as many and as big fish, as a rud costing twenty-five dollars. Other necessary tools are a landing net for sheepshead and small bass, and a large gaff hook with a handle four or five feet long. A pocket revolver for shooting sharks and big rays, $I$ have seen used in a boat.

As most of the fishing is done from a boat in shallow water, a light flat bottomed skiff ten or twelve feet long and from two and a-balf to three feet wide, is most convenient.

For rod-fishing, one angler is enough in a boat, the stern being the only comfortable place to fish from. Of hand-line fishermen three or four conld be accommodated in the same space. The most essential thing of all, is to have a boatman who is handy with a casting net, for on this depends your supply of mullet bait. Your boat should be anchored at bow and stern, so as to hold her in position against wind and tide; a few feet one way or the other often makes great difference in the eatch.

I extract from my journal, kept for ten years in Florida, the following record of my eatch of different kinds of fish. In some seasons otie kind inay be scirce, in the next it may be plenty. These years show about the average.

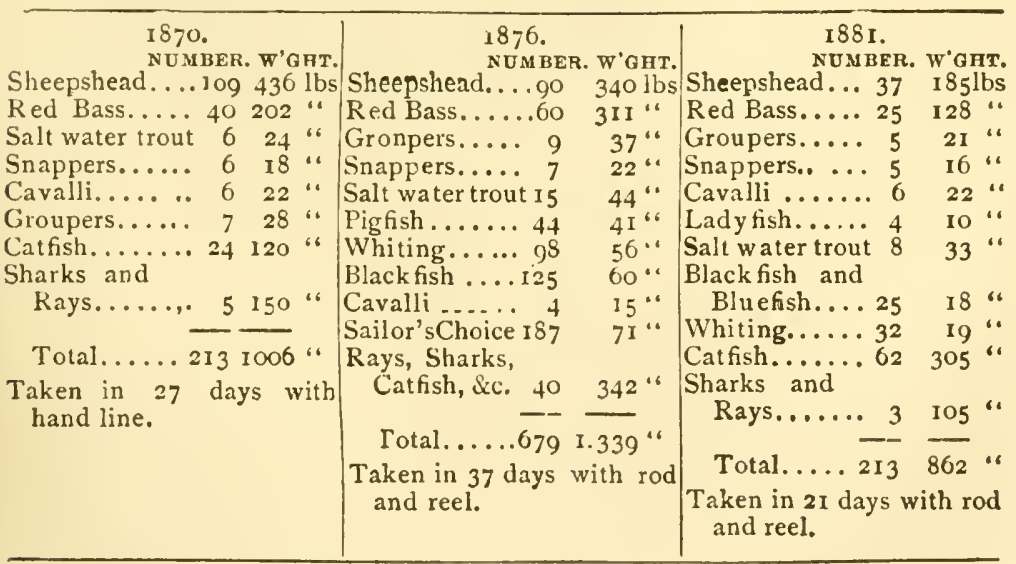

In writing of the fishes of the Sonthern coast, we at once meet 
with the difticulty attending a confusion of names. Every speaies has its local name, and the same is often in different places given to different species. For instance Megulops thrissoides is sometimes called jewfish, in another locality it is called tarpoin; the first name belonging to a gigantic perch, the latter to a monster herring; while in a thrrd place the name jewtish is applied to the rockgrouper.

Except the incomplete work of Dr. Holbrowk on the Fishes of South Carolina and Georgia, I have not been able to find anything on this subject, save a eatalogue by $\mathrm{Dr}$. Gill, and another by ${ }^{\circ} \mathrm{Dr}$ Storer, both I think refering to South Carolina. Some of these species are mentioned in the great work of Cuvier, of others I have found no deseription.

Some species which oecur along the coast from Cape Cod to Florida, figme under different names at aimost each degree of latitude; snch as the striped bass or roektish, the bluefish, horse mackerel, skip jack, or talor fisls. To add to the confusion, it is the fashion of late to alter the seientific names of the whole animal creation. Our well known and valuable sheepshead was formerly Sargus ovis; the new sehool of naturalists call him Archosurgus probutocepalus - a name long enough for a whale. Therefore, in the absence of any well recognized standard names, either scientifie or trivial, we ean only give the one in common use where the fivloccurs. 


\section{CHAPTER II.}

\section{The Chansel Basw.-Scicenop: oscellata.-Gill.}

Called red drum on the Virginia Coast: spotted bass or spot, in South Carolina red bass or channel bass, in Georgia and Florida; red fish, in Now Orleans.

It is a stoutly built, thick bodied fish, with large head; color va. ries with the water it inhabits, those taken in the ocean surf are of a golden hue on the sides; back, reddish brown; belly, white; taken in or near fresh water they are copper red; all have the black spots near the tail, sometimes three or four in number. Scales, large, on a twenty pound fish the size of a nickel coin and a hoe is often used to remove them. These seales are used to some extent in Florida for ornamental work.

In size the red bass runs from one pound weight to fifty; the largest being taken in summer and antumn. Those of four to six pounds usually run in schools of a dozen or more, and are called "school bass." The larger specimens from twenty to forty pounds are commonly found singly or in pairs, and go by the name of "channel bass." In the list of fishes collected at Wood's IIoll, Mass., the red bass do s not occur, though some southern forms have been found there. Captures of this fish have been reported at Barnegat Bay, which is perhaps the northern limit of its summer migration.

In the winter and spring we find this bass coming into the bays and inlets with the tide and ranging along the shores and on the flats in search of food, which consists of small fish, principally mullet, mollusks and crustacea. It is a fish of omnivorous and huge appetite, a bold biter, and has none of the shyness of the striped bass, frequently taking the bait alongside the boat. 'When anchored 
on the sand-flats neal the inlet, fishing for the schools of bass as they come in with the tide, I have noticed that they will appear to be eurfous abont the boat, they will approach and swim around it as if to examine it. At such a tine nearly the whole school may be taken, and when a bass is being on the rod others will follow it nearly to the boat.

During the cold northerly winds which sometimes prevail for two or three days in winter on the Florida coast, the bass retires to deep boles, and cannot be induced to bite until a change of weather occurs. It is a warm weather fish, and in the summer appears on the coast in immense numbers and of large size. As the fishermen say, "the surf is red with them." At this season it is in its best cond:tion for the table, being firm of texture and well flavored; one of the best of the eoast fishes, either boiled, broiled in steaks, in a chowder or fried as is the usual method of cooking. A fish of ten or fifteen pounds is about the best size; the large ones are rather coarse, the smail ones have less flavor.

As a sporting or game fish the rank of the red bass is high. A strong and persistent fighter when hooked, making long runs in open water, and not coming to gaff until exhausted, it is the favorite object of pursuit to anglers on the Florida coast. - From its open way of nighting, if the angler has one hundred yards of good line on his reel, and is not impatient, he is pretty sure of killing his fish, up to forty pounds. The hand-line fisherman who works by main - irength is apt to lose the big ones.

The same sort of tackle that is used in Northern waters for striped bass, answers well for the red bass, except that a sinker of one or two ounces weight is used here in casting from the reel, and it is unnecessary to use gut or delicate tackle, and gut is more apt to be cut by the oyster shells which cover the bottom in the best places, than a length of line which we use for a snood.

A bass of twenty-five to forty pounds will consume from twenty to forty minutes in the capture with rod and reel, the old rule of one minute to the pound holding good with this fish. The writer has taken some hundreds in various ways-on the bottom, with a float at mid-water, and on the surface with spoon or feathers-and 


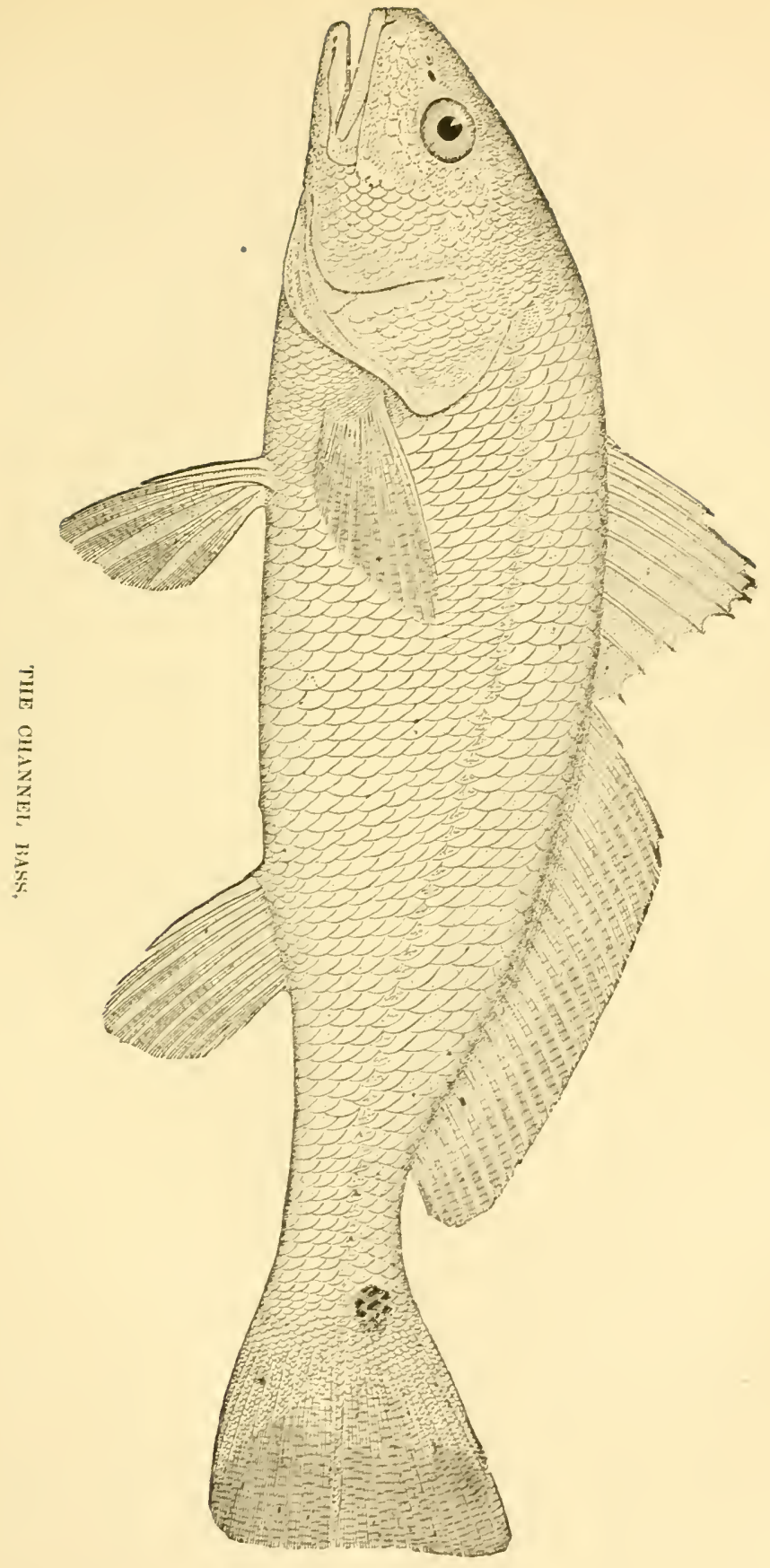



considers that from its abundanee, its free biting, and its methorl of fair fighting when hooked, the red bass is on the whole the most valuable of the Southern game fishes.

Twenty-five to thirty red bass have been killed by one rod in a day on the IIalifax River, weighing in the aggregate some 200 to 350 pounds. The largest bass ever taken by the writer weighed thirty-seven pounds, and the struggle lasted about forty mintes. It was taken from a boat, and the fish towed us nearly a hundred yards before it came to gaff. Its mate, weighing over twenty-five pounds, was soon after taken by my boatnan. The next in size captured by ne weighed thirty pounds, and its mate, weighing twenty-eight pounris, was hooked directly after by my companion in the boat, also a rod fisher, and the contest went on for thirty or forty minutes at each end of the boat. The mouth of the red bass is tough, requiring a smart stroke to fasten the hook, bnt once fastened the hold seldom gives way. I have never tished in Florida waters in summer, when the bass run largest, but the hand-line fishermen of those parts tell of catching them at that season not unfrequently of the weight of fifty pounds.

At the Indian River Inlet bass and all other fish of these waters are found in great abundance, and of larger size than we find them in Halifax Inlet. In the year 1870, while fishing in the Indian River we found the fish so plenty that we turned loose four-fifths of our catch, the other fifth amply supplying our wants.

In April and May, when the sea water is warm on the beach, I have found pleasant sport in wading out into the surf, or near it, and casting my mullet bait into a depression or slough which runs along the shore just inside the surf. Here the bass come in to feed at certain times of tide, and I found that they wonld make a harder thint than in the river inside the inlet, though of about the same size, from four to six pounds. Sharks are plen:y in the surf, but do not often come into the sloughs, for fear of being left high and dry, so that one can safely enjoy the combined pleasure of angling and bathing. There are some old wrecks of vessels imbedded in the sand on this shore; the tides have washed out deep holes about these wrecks, where bass, sheepshead and trout are found.

bands of roving hogs live on the beach and in the adjoining 
scrub, which I fonnd very ready to steal any fish that I left exposed ; and once I found a couple of marsh ponies derouring my bass. In this region man, beast and bird all live on the fruit of the sea, and there is enough for all-those destructive engines, the pound nets and the mile long seines, not having been introduced.

The red bass spawns in August and September in the inlets and bays, as I am informe 1 by Florida fishermen, and deposits a large amount of eggs, making it i prolific species. It is a roving fisin, and must be sought for among its haunts, which are rarious; deep chan nels, mud flats, oyster beds, and along the marshy shores, all of winl it yisits at different times of tide.

[Since writing the above, I have received a copy of Jordan and Gilbert's "Sy" nopsis of the Fishes of North America," from which I take the following description of the above species:]

Sciona ocellata-Gthr. Channel bass-red bass. Grayish silvery, iridescent; scales with dark spots forming faint irregular undulating stripes; upper part of base of caudal with an oval black spot as large as the eye, bordered by white or orange; this spot is often duplicated.* Body rather elongate, not much elevated, compressed behind, an almost even curve from snout to base of dorsal; preopercle distinctly serrate; eye large; one and a-half in snout; five and a-half in head; gill rakers short and thick; mouth large; maxillary nearly reaching the posterior margin of the orbil; caudal truncate; second and spine rather strong, two-thirds as long as first ray; pectoral fins very short, not reaching half-way to anal; lower pharyngeals narrow, with conical teeth. Head three and a-third; depth three and a half. D.X.I. 25 ; A.IH. 8. Lat. . 50. Cape Cod to Mexico. Common Southward. 


\section{CHAPTER XY.}

The Southern Teakfish.

Salt Water Trout-Spotted Sea Trout-Cynoscion carolinensis (Gill).-This species is allied to the weakfish or squeteague of the western coast, but it is a handsomer and better fish. Color, silvery sides, darker above, with rows of black spots above the lateral line. Belly silvery. Head small, mouth large and well supplied with sharp teeth; in form and color much resemblng the lake trout of northern New York, but wanting of course the adıpose fin. Predacious in habits, takes a mullet bait eagerly, fights hard on the hook, and gives good sport with rod and reel, though I think it is less enduring than the red bass.

This fish does not well bear keeping, but eaten fresh from the water is sweet and well flavored. It is largest and most abundant in summer and fall, when it may be heard on a still nignt snapping along the shore in pursuit of small fish. I have taken them weighing from two pounds to six, at Halifax Inlet in winter. Very large specimens are taken in Mosquito Lagoon, south of New Smyrna, weighing, as I am told, as much as twenty pounds. It takes a bait on the bottom, at mid-water or on the surface, and I have killed them in fresh water while trolling for black bass, in Spruce Creek, a tributary of the Hahtax. They were of small size, about two pounds, and were taken with a spoon, and I believe they would take $2 \mathrm{tly}$ in swift water. This species spawns in suly and August, in the bays and inlets; is not as abundant as the red bass. The same tackle may be used for this fish as for the red bass. The common 
bait for this fish is cut muilet, but from the habits of the trout 1 have no doubt that live bait wonld prove more attractive, as it is found to do with the red bass. Probablr also to the sharks, which abound in these waters, and mate trouble by cutting off lines anci taking the fish from the angler's hook as he plays them.

This is also a roving species, and is taken on the same grounds as the bass-preferring, however, tiheways and rapid currents. We seldom take more than four or firs salt, water trout in a day's fish. ing, together with other specis:. (Bne great pleasure in angling along this coast is the variety of tish which one encounter, and you can never predict whether your next capture will weigh one pound or twenty.

DESCEIPTION FROM JORDAN AND GILBERT'S SYNOFSIS.

Cynosion macatu $m$-(Mitchell. Gill).-Spotted sea trout. Bright silvery. darker above; back posteriorly with numelous round black spots as large as the pupil; both dorsal and candal fins marked with similar somewhat smaller spots much as in a trout; anal dusky. Maxillary reaching to posterior edge of eye ; can? ines moderate Longest dorsal spire not quite half the length of the head; cauda. lunate. Head, $3 \frac{1}{2}$; depth 5. Eye large, about 6 in head. D.X-I, 25; A. I. I0 ; Lat. I ; about go. Virginia to Mexico ; very abundant southward. 


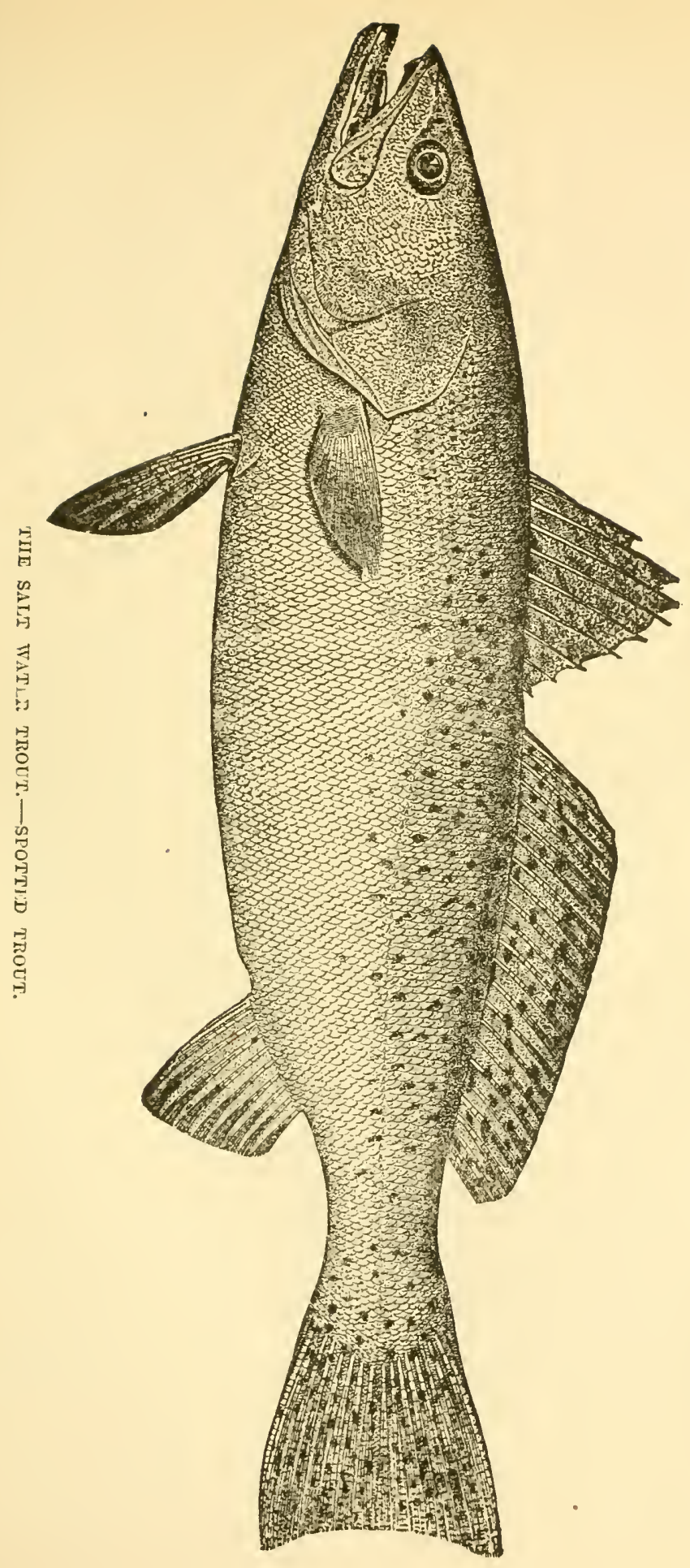



! CHAPTER IV.

The Red Grouper.

Red Grouper.-Epinephelus morio-(Cuv. Gill). - I give to this well known and valuable food fish of the Florida coast the name affixed to it by scientists, as I suppose, though I have not identified thespecies. Jordan and Gilbert in their Synopsis write of the groupers, that the synonomy of the species is much confused, and the name to be adopted uncertain. Their description of E. morio seem more like the common grouper than that of any other which they describe. Holbrook in his Fishes of South Carolina describes it under the name of Serranus erythrogaster.

The name "grouper" is found in Roman's List of the Fishes of the East Florida Coast. How far north it occurs I do not know, but it is abundant and large along the island of Cuba, as I am informed. It is a thick-set, robust fish, of the perch family, with hard spines in the dorsal fin ; large head and mouth, with many sharp teeth. Color, light olive, mottled with darker lines, like tortoise shell. Fins tipped with blue ; inside of mouth red.

The grouper is taken on the bottom in deep channels and holes, near the roots of the mangrove trees, under which it makes its stronghold. It is never found far from this fortress, to which it retreats when alarmed, or when hooked. The usual bait is mullet, either cut or whole; the latter being more attractive, and taking the larger specimens. In size it runs from half a pound to fifteen pounds, and is seldom or ever taken with the cast net. It is voracious, but shy, 
and easily alarmed, and after one has escaped from the hook, or after the capture of two or three, the others seem to take fright and will seldom take a bait in that place for some days. When hookedand it is always near its hole that a grouper takes a bait-it makes straight for the roots, and can only by main force be kept from getting under them, so that only those of moderate size can be taken with rod and reel-say up to five or six pounds weight. The larger ones can only be landed with a heavy hand line. It is a trial of strength between the man and his tackle and the fish; the latter, if of large size, often proving the stronger, and breaking line or hook, or reaching its fortress, from whence it cannot be dislodged, the result being loss of tackle and of patience. The rod fisher loses half the number of groupers that he hooks. I think I lave never been able to kill on a rod a grouper over five pounds in weight. I have hooked many large cnes, but they always got the better of me. Other rod fishers may perhaps have been more fortunate or skillful. A friend who was fishing near me in the Halifax River killed a pair of these fish at once, weighing four and five pounds, but I think the two ran different ways to their respective holes, and so pulled against each other. If they had both made for the same hole I think they could not have been stopped. As is well known to anglers, the first rush of a strong and heavy fish cannot safely be resisted, and the grouper makes only one. If he wonld only tight in open water like the red bass, he could be tired out; but he gives the angler no play.

The best day's sport I ever had with the groupers was in the Halifax River, I think in April, 1875, with B. C. Pacetti, a very skillful tisherman of that coast. He took me in his skıff to a deep hole in a creek anong the Mangrove Islands, which he said had not been fished for a long time, and for an hour the sport was fast and furious. 'The groupers were hungry and took our mullets eagerly. I killed three of 3,4 , and 5 pounds, and lost three still heavier by the breaking cf my line. My companion, who used a cod line, killed four of $5,6,6 \frac{1}{2}$ and 7 pounds, and had his line broken once and his hook once, by monsters which he could not laandle. Seven groupers from one hole was uncommon luck, but the survivors were so.much 


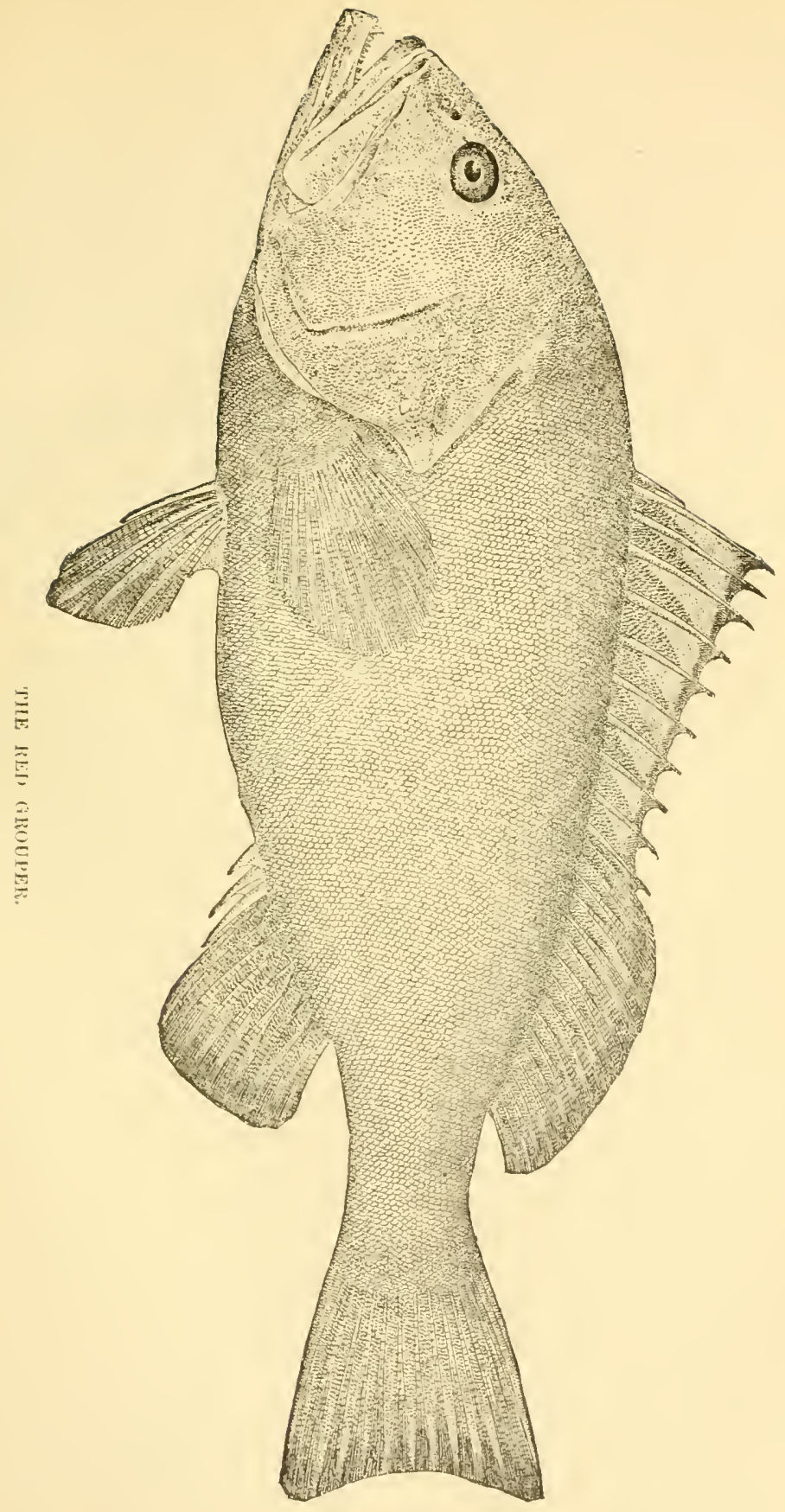



alarmed that I think they deserted the spot; at any rate, I have often tred the place since without getting a bite.

The fles of this speries is fine, rich and well flavored, and is highly prized, perhaps partly on account of the ecarcity of the fish and difticulty of taking it. To my taste it much resembles the red bass when in good condition.

\section{JORDAN AND GILBERT'S DESCRIPTION.}

Epinephelus morio-(Cuv.-Gill). Red grouper, brownish, marked with ash ; salmon color below soft parts of the vertical fins margined with blue; body oval, compressed above; profile oblique gently curved; mouth terminal, large, somewhat oblique ; maxillary reaching beyond eye; eye about as long as snout. Head 21/2; depth 3. D. XI. I7; A. III. 9; Lat, I. I06; cæca 28. Atlantic coast, chiefly southward. 


\section{CHAPTLR V.}

The Rock Grouper. - The Puni'ano.

The Rock Grouper--So called by the Florida fishermen. I haw never seen any account of this speces, scientitic or otherwise. It differs from the common grouper in many particulars. It is a thickset, heavily built fish, with a large head. Inhabits rocky bottoms and deep holes; ratier sluggish, though a strong and heavy puller. Color, dark brown with lighter marks and lines; scales small. Average weight five or six pounds, and has been taken in the Halifar River weighing twenty-eight pounds. It is easier handled on a rod than the common grouper, not running to a bole like that fish, but fighting in open water.

It is a rich and well flavored fish, superior, in my opinion, to the last named species. Some years this species is quite common, so that some are taken every day. In other years they may be scarce, and this we find is the case with many species on the Florida coast. On the northern coast we know that the same thing occurs, and there it is often attributel to the effects of pound nets and seines and overfishing.

On the Florida coast there have been few of these destructive engines, and the cast net is the only net used, and that merely for the needs of the scanty population of those shores. Except in the neighborhood of St. Augustine and Jacksonville, the amount of fisl; taken by man is very small. Marine birds and fishes of prey are the principal destroyer of food fishes. In fact, the waters are almost 


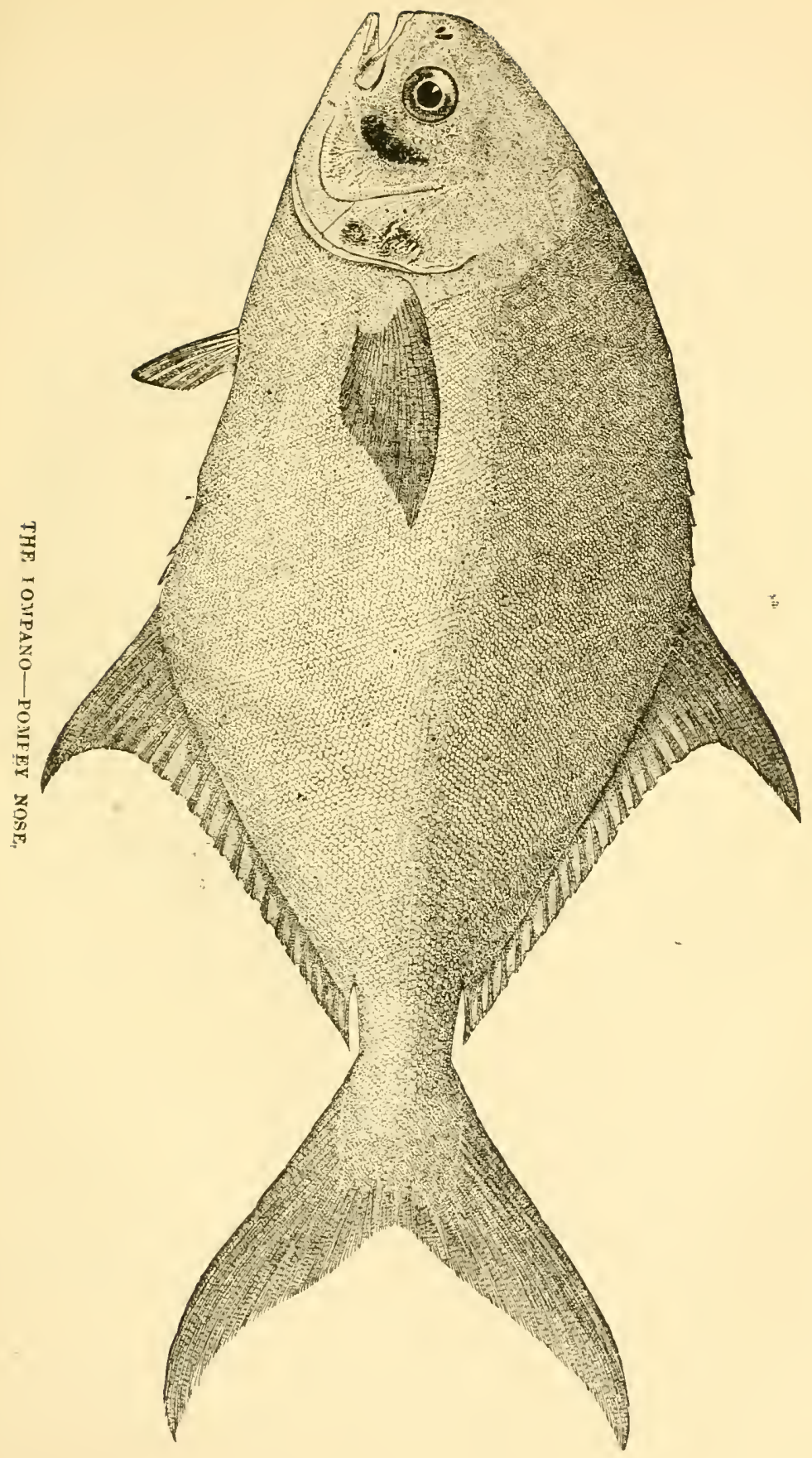



in a state of nature; and yet this abundance and scarcity of many species oceurs here from year to year. The rock grouper is taken with inullet bait, on the ground.

Since writing the above, I find on consulting Professor Jordan' Synopsis, a species there described under the name of Rhypticus ma. culatus, which much resembles the rock grouper.

\section{DESCRIPTION.}

Olive brown above, with scattered whitish spots; below, pale slate color Back regularly arched from snout to caudal fin. Mouth large, maxillary extending beyond orbit ; lower jaw longer than upper. and projecting much beyond it in closed mouth. Pre-opercle with two stout spines; opercle with three. Pectorals rather large. Yertical fins high. Dorsal spines slightly connected with the soft rays. Head 3 I-3; depth 3. D. II, 25; A. I5. North Carolina to the West Indies. Commen name, soapfish.

Pompaxo- Ponperiose. - Truchynotus carolinus. - (Linn. Giil.) - On the South Carolina coast this species is called "Crevalle;" in New Orleans and Mobile, pompano or pormpeynose; the same name is given it in East Florida, and it is often confounded with the previonsly described species, which it much resembles in appearance, though not in babits or in quality. The general form is that of the cavalli, but deeper in proportion iv its length, with a more obtuse smour, a sinaller month with few or no teeth, color, a hyiliant frostod sulver below, above dark blue, changing to green and yellow. It is a bottom fish, living entirely on mullusks and crustacea, as I beheve - which probably give it the delicacy and flaror which distinguisn it above all other species in the salt water. The fish which more resembles the yompano in these particulars, the whitefish of the Great Lakes, Corregonus supiclissimus (Agr.), has also been found to subsist upon crustacea exclusively.

The sheepshead, which lives upon similar food, has also a similar richness and delicacy of tiesh, though in a less degree than the pompano, which wherever it is known, takes precedence over all other food fishes of our waters. Like all other delicacies it finds its was to New York, but probably loses much of its excellence on the way -all fish shonld be eaten on the shores of theil native waters. The Fuglish epicure crosses the Atlantic to eat the canvas-backed ducks 
in Baltimore, and the pompano is to the fish gourmand worth a journey to the Gulf coast.

The pompano is taken on the ocean beach of East Florida in the summer months with the cast net, in size from one pound to six, average, two pounds. It spawns in March, as I learn from the Florida fishermen.

While fishing for sheepshead in the Halifax River in 1870 , I captured a pompano with rnd and clar bait. Its action on the line was peculiar, and different from that of the cavalli; it ran in circles, and fought vigorously for a long time, and Bartolo Pacetti, who was with me, one of the oldest and most experienced fishermen on the cr,ast, said that was only the second instance he had ever known of taking the pompano with the hook. My specimen weighed two and a-half pounds, and being cooked and eaten within three hours of his capture, he was all my fancy painted him.

In Jordan and Gilbert's Synopsis, four species of Trachynotus are described as occurring on our coasts, and the description of the above species is as follows:

DESCRIPTION.

T. carolinus-L. (Gill.) - Common pompano. Uniform bluish above, sides silvery, golden in the adult, without bands; fins plain silvery or dusky. Body ob. long ovate, elevated, profile forming a gentle curve from the middle of the back to the snout, where it descends abruptly. Dorsal and anal falcate, their lobes reaching when depressed nearly to the middle of the fin: pectoral reaching to opposite the vent. Gill rakers short, slender in the young, becoming thick in the adult. Head 4; depth 2 I-3. D. VI-I, 25; A. II-I, 23, L. I8 inches. West Indies, north to Cape Cod. The most valued food fish of our Southern. waters. 


\section{CHAPTER VI.}

'The Civalli, or Crevalle. - The MIangrove Snapper.-The Crab Eater, or Sergeant Fish.

Cavalli, on Cretalle-This is a Carangus, but which of the species describerl by naturalists as visiting our coasts, I an mable to say. It is, however, a valuable fish for sport, but of only moderate quality on the table; the flesh being some $\rightarrow$ hat oils, with black streaks, like that of the mackerel.

The cavalli usually appears at Mosquito Inlet, on the east coast of Florida, in April in Jarge schools, and is discovered by the commotion it causes among the small fry, especially mullet, which it hunts and devours incessantly, often driving them on shore. In the Indian River and further south it occurs all winter.

In form the cavalli is deep and compressed, with a long double dorsal fin extending to the tail, which is deeply forked. The colors change rapidly after the fish is taken, like those of the dolphin, green and yellow predominating. Eyes large, mouth ditto, with sharp conical teeth. Grows to the weight of ten or twelve pounds, averaging perhaps three. Very strong and active, and fights to the last on the hook, dying as soon as it leaves the water. It is very voracious, taking all sorts of bait, on the bottom, at mid-water, or on the surface-cut mullet is commonly used. I have taken it while trolling with a spoon, and I am told that it will rise to a fly. A cavalli of four or five pounds must be very carefully haniled on a rod, as its movements are rapid and unexpected; leaping out of the 
water, running under and arouni the boat, and conciucting itseit in the gamest fashion. Spawns in May, in the ocean.

One spring day, while at Halifax Inlet, being attracted by the sigh of great schools of eavalli chasing the mullet along the shores, I went out with my rod, and found at the mouth of a creek the shore shining with the silvery bodies of small mullet and menbarlen, driven ni) high and dry by their ravenous pursuers, while a number of brown pelicans were filling their pouches with them, and varions gulls and other sea birds were also feeding on them. The river fairly boiled with the rusbing hosts, and attacbing a bight spoon to my line I cast it into the current. Directly it was seized by a cavalli, which in due time I secured, and afterward several others. While the schools of mullet and cavalli remained near, the sport was good, but soon the crowd of fursued and pursuers passed by up the river with the tide.

Jordan and Gilbert describe eight species of Caranx on the coast of North America, of which $C$. hippus, (Gunther) the horse crevalli, is most abundant, and probably our tish.

\section{DESRRIPTION.}

Olivaceous above ; sides and below silvery or golden; a distinct black blotch on opercle, and one on lower rays of pectorals, the latter sometimes wanting; axil of pectoral dusky ; anterior edge of dorsals black; upper edge of caudal peduncle dusky. Body oblong, twe anterior profile very strongly arched. Head large and deep. Mouth large, low and nearly horizontal below añis of body; lower jaw included : maxillary extending to nearly opposite posterior border of eye. Teeth teeth; teeth in lower jaw in one row, : distinct canine on ea side of symphysis in upper jaw in a broad villiform band; an outer series of large wide-set conical villiform teeth on vomer. palatines and tongue. Lateral line with a wide arch ; iss length three fourths that of straight part : plates not covering all of straight part. Dorsal spines short, rather stout; procumbent spine obsolete. Gill-rakers stout, not very long, fifteen below angle. Occipital keel sharp Eye not very large, longer than snout, 4 in head. Pectoral falcale, longer than head. Breast naked; with a small patch of scales in front of ventral only. Caudal lobes equal. If ear $3 \frac{1}{2}$; depth $2 \frac{1}{2}$; Lat. I (scute;) about 30 . D. VIII-1, 20; A. II-1, I7. Lape Cod to West Indies; common southward.

Maxgluve Sxarper-Tutjanes aurombens.-Profeser Jorlan's description is like our Sumb Florida fish, except as to canine : veth. 


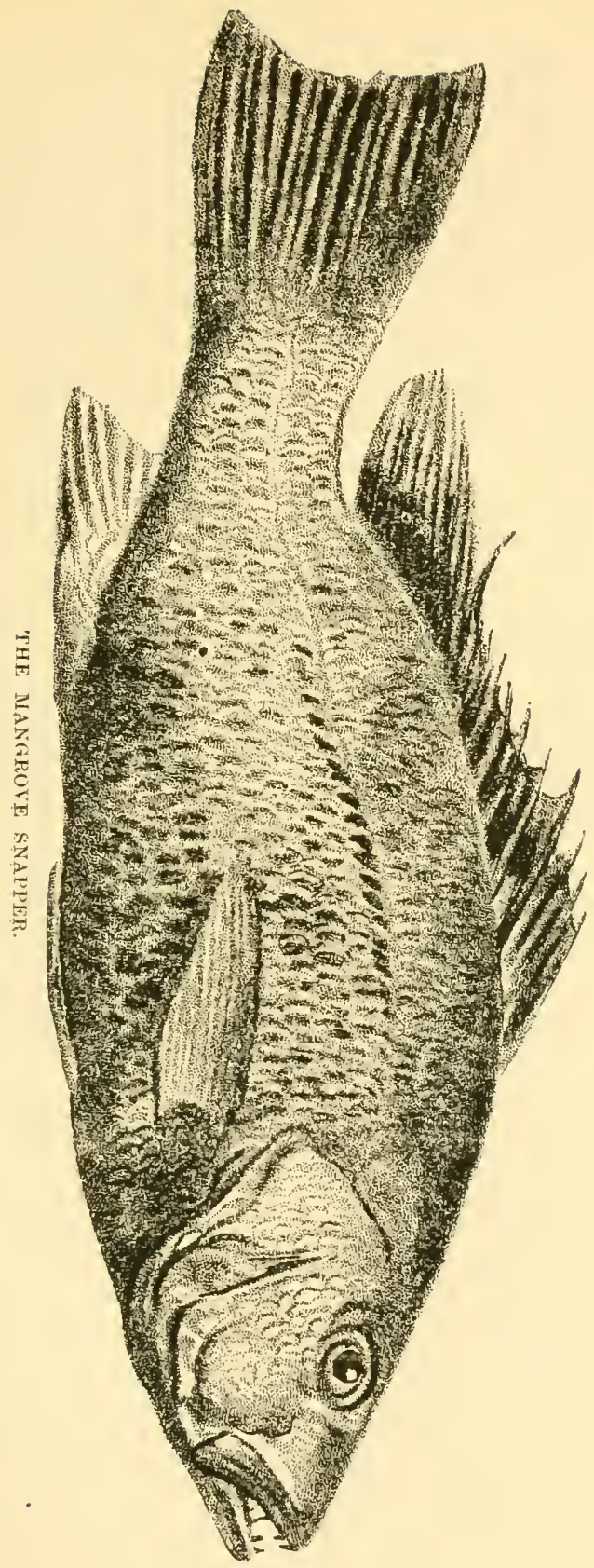



1 find the name "mangrove snapper" in Capt. Roman's list, and it is a significant one, as this species lives in holes among the roots of that tree. Jordan places it in the same genus with L. blackiforlii, the red snapper, which is an ocean fish of different habits.

Like the grouper, the mangrove snapper is stationary, seldom ven. turing far from its retreat, in which it takes refuge when alarned.It is one of the most shy and cunning fishes of this coast, and long casts from the hoat are necessary to beguile it. No doubt fine tackle would be more successful than the coarse hand lines commonly used, but the snapper has very sharp teeth, and silk worm gut would stand no chance. It makes for its bole with a rush as soon as it feels the hook, after the manner of the grouper, and is a more active fighter than that fish, though, perhaps, not stronger. Cut mullet is generally used for bait. Cast as far from the boat as possible, into the a deep channel near the snags; let the bait rest gently on the bottom for five or ten minutes, and as soon as the bite is felt get the snapper away from the bank-otherwise fish and hook are gone.

In form the mangrove snapper resembles the small-monthed blackbass. Color, a reddish brown, with golden reflections. Hard spines in dorsal fin. Head, small, with wide mouth furnished with sharp teeth. Canines very large, with which it snaps savagely when captured. Eye very large and bright, with golden colored iris. Scales largc. 'T'he large eyes seem to indicate nocturnal habits, confirmed by the fact that the snapper feerls more freely at night, and on dark days. The fishermen say that when placed in a car alive with otber fish, the snapper will mangle and devour them. It is not sol:tary, but is often found in considerable numbers together in deey holes, and is thus captured with the cast net.

Size in Halifax River, from halt a pound to five pounds. In the Indian River I have taken them of seven to eight pounds in weight, and it makes a vigorous resistance when hooked, showing good sport if kept away from its hole. Is of excellent quality on the talle and keep's well.

JORD N AND GILEERT'S DESCRIPTION,

L. aurorubens-(Cuv.-Val), - Mangrove Snapper. Vermillion-red above, rosy below : sides with cblong irregular yellow spots; dorsal and Dectoral fins red: 
ventral and anal lighter. Body, oblong-elliptical, moderately compressed, not alevated. Mouth, moderate. without distinct canines; longue with a large oval patch of teeth, besides which are five or six smaller patches; nostrils round, near together. Preopercle finely serrate, its notch obsolete. 'Gill-rakers very long and slender. Dorsal spines rather slender; $2 \mathrm{~d}$. anal spine a little longer than $3 \mathrm{~d}$.; caudal fin lunate, its lobes not attenuate. Head $31 / 2$; depth 3 . D. XII, I I ; A. III, 8; Lat I. 54. L. I.54. West Indies, North to S. Carolina and Florida.

Crab-Eater, or Sergeavt Fish.-Elacate canadu.-(Linn.Gill.) - The trivial name "sergeant fish," comes from the dark stripe on the side, resembling that on the trowsers of a non-comuissioned officer. In shape the crab-eater resembles the pike of fresh water, Escr-being long and cylindrical, with a similar formation of head and jaws. Its habits also are similar to those of the pike, lying under weeds and banks, waiting to seize upon smaller fishes. I have not met with it in the Halifax River, but have found it abundant at the Indian River Inlet, where it averages three feet in length, weighing five or six pounds. Takes mullet bait eagerly. In game qualities and value of flesh it is perhaps equal to the pike-not very high praise.

JORDAN AND GILUERT'S DEECRIPTION.

E. canadensis-(I inn.-Giil )-Crab-eater, Cobia. Olive brown ; sides with adisfinct broad band of darker, and a less distinct band above and below it; below, silvery. Heal much depressed; month moderate, the short maxillary reaching front of orbil, Pectorals broarl and falcate ; caudal deeply emarginate, the upper labe the longer. Lateral line wavy and irregular, descending posteriorly. Head $4 \frac{1}{2}$ in length; depth $52-3$. D VIII-I, 26; A. II, 25. L 5 feet. In ail warm seas, occasional on our Allantic coast in summer. 
CHAP'TEI VII.

The Lamifish, or Bore Fis j. -The Jenfish. - The Tarpum, ('R TArPon.

LADYFISH-SKIP JACK-BONE Fish-Albula conorhynchus(Block-Schne1der.)- $\mathrm{M}_{y}$ description is as follows of freshly caught specimens : Length, one to three feet. Body, slender and cylindical. Head, 1-5 the whole length; eyes very large, iris yellow; mouth large; teeth small; labials long and large, with fine teeth on edges. Scales small. Fins all soft rayed; dorsal high in middle of the back, 18 ; pectoral 16 ; anal 10 ; tail deeply forked. Color of back, dark blue; sides and helly silvery ; head greenish.

I'he ladyfish, though not valuable for food, it being a mass of bones and fat, like a menhaden, is so active and vigorous on the line that it affords more sport than any other species on the coast. "No sooner is it hooked than it begins to throw itself from the water in successive and lofty leaps, then darting round and round the boat, under it and over it till exhausted, or till it escapes by casting out the hook, or cutting the line with its sharp labials. The mouth being tender, the hook does not take a firm hold, and one-half the number hooked usually escape. I know of no species which equals it in activity ; even the grilse, or young salmon, makes fewer leaps, and is less rapid in its play. Like the cavalli, it feeds both at the bottom and on the surface, and could probably be taken with the fly or spoon. It appears in the Halifax River in April in schools in chase of the mullet and other small fry. 
JEWFin-Promocrops guasa-GiLL. - This is a giant pereh, resembling in outline a much magnified tautog or blackfish. It grows to the weight of five or six hundred pounds, and of course it is only the smaller specimens that can be taken with rod and reel. I was once present at the capture of a young jewfish, weigh. ing about twenty pounds, and it gave a fight of half an hour's duration. When brought to table it proved to be a rich and well thavored fish.

It is a fish of great strength, and the large ones will break hooks and lines which are large enough to eapture good sized sharks; this I have myself seen in the ease of a shark hook one third of an inch in diameter. I have myself hooked a large jewtish, bow large 1 never knew-all I saw was the sweep of a huge tail a foot broad, and away went my tackle.

The jewfish has the habit of thoating along on the surface with he tide, apparently asleep, and it is then sometimes shot. One wa killed in this way in Sprnce Creek, a tributary of the Halifax River, a few years a go, by Mr. B. C. Pacetti, a fisherman of those regions who supposed it to weigh 600 pounds, and he was familiar with this fish, having captured many of them. He once fastened to a large jewfish which he found floating near St. Augustine, and it towed his boat off seawards till he was joined by several other fishing boats, and among them they managed to capture it; when they got it to town there were no seales in St. Augustine that could weigh it whole, so they eut it up, and it weighed over 500 pounds.

Even a specimen of that size is said to be good erting, so that this species must furnish perhaps the largest of edible fishes. A plaster cast of a jewfish weighing probably forty or fifty pounds, was shown in the fisheries department of the Centennial Exhibition in Philadelphia.

How far north this speeies oceurs I am unable to say, but it appears to be a stationary speeies, found on both coasts of Florida, and abounding in tropical seas. Found in deep holes and channels in the salt water somds and inlets. Takes mullet bait.

Jordan and Gilbert's synopsis describes only this one species of Promocrops, as follows: Yellowish olivaceous, witb numerous 


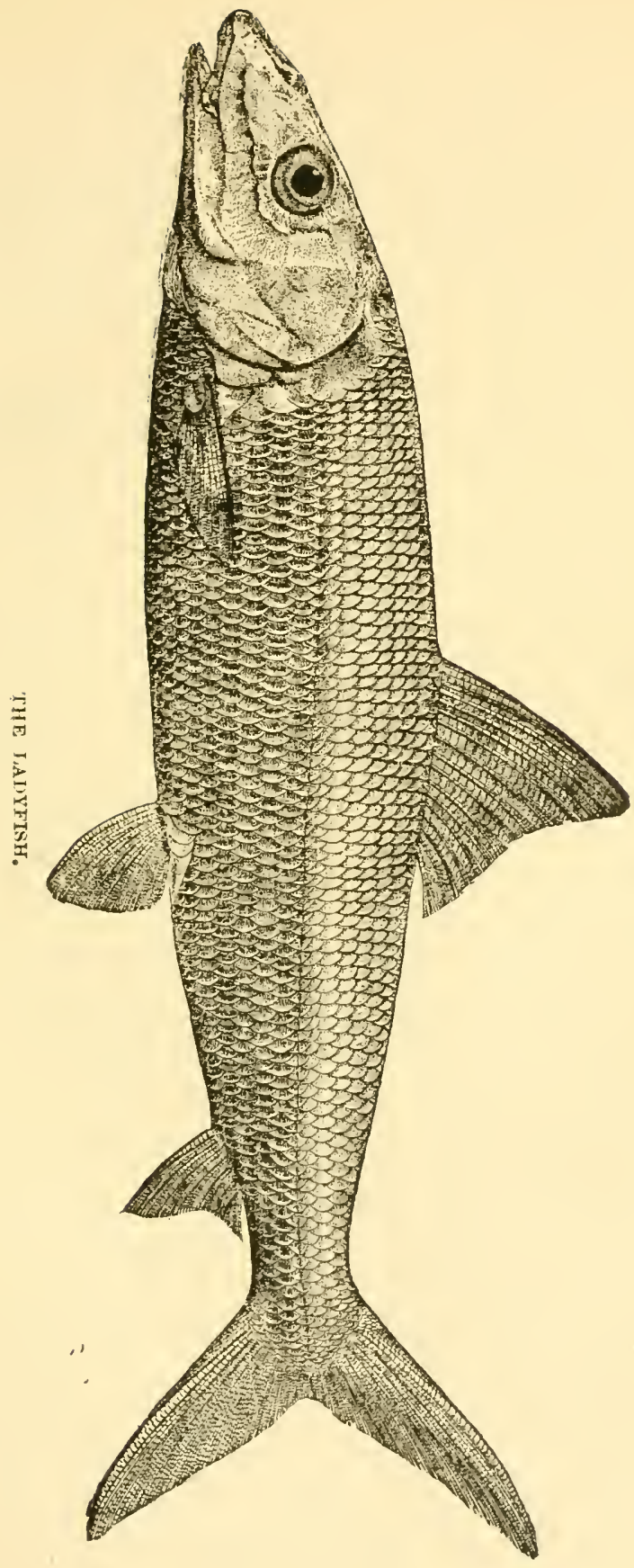



brown spots. Body more compressed above than below. Mouth large, maxillary reaching beyond the orbit; preopercle feebly serrated; opercle with three flat points; fins all very low, candal rounded. Head 3 1-6; depth 4. D. XI., 16; A. III., 8. West Indies, north to Florida; reaches a weight of 400 or 500 pounds.

TArpur-Tarpom.-Megulops thrissoides. - (Gunther.)-Captain Romans includes this species in his list of the fishes of East Florida, and spells the name with the o. Imagine a herring-shaped fish, fivo or six feet long, with brilliant silvery scales, the size of a half dollar, in schools of a dozen or twenty, leaping from the blue surface of a summer sea. This is all that the angler usually sees of the tarpum. Sometimes one of these glittering rushing monsters takes the hook. What follows? The line runs out with great speed till it has all left the reel, where it parts at its weakest point, and the fish goes off leaping, seaward. When hooked on a hand line similar results follow. No man is strong enough to hold a large tarpum, unless he is provided with a drag, or buof, in the shape of an empty keg attached to the line, which may retard or eren stop the fish, after awhile. Aided by a buoy the tarpum is sometimes taken with a burpoon, or grains.

I have heard of cne instance of this fish being killed on a hand line. As usual, the line was snatched from the hands of the fisherman in the first rush, and the tarpum went leaping down the river, but the heavy leaden sinker struck it on the head and stunned it, so that it was picked up by means of a boat. This happened in the Halifax River. One was killed a few years ago in the Indian River, as I am eredibly informed, with rod and reel by an angler from Philadelphia, after a contest of some hours. The fish was over six feet long and weigrhed more than 100 poumls-certainly one of the greatest angling feats on record. It is a fish as much more powerful and difficult to nandle on a rod than the salmon, as the calmon is more powerful than the black bass. This may perhaps be thought a rash assertion, but it is gathered from my own experience. Twice I have hooked a tarlum, aud twice I lost my tackle, withont shock- 
ing the fish in the slightest degree-and I have killed a twenty-four pound salmon, fresh run from the sea.

, Those anglers who have exhausted the pleasures of salmon fishing and sigh for new worlds to conquer, may betake themselves with their heaviest roas and two hundred yards of line to the Florida coast in spring; there, at the mouth of the St. John, or at Halifax or Indian River Inlet they will find foemen worthy of their steel. Should they succeed in killing a tarpum, let it be stuffed and hung up as the choicest trophy in their museum.

The brilliant scales of the tarpum are used in Florida for the manufacture of ornamental jewelry. The fish itself is said to be good eating.

-Of the genus Megalops Messrs. Jordan and Gilbert write: "The species are of very large size, the largest of the Clupeoid fishes, found in all warm seas. The name comes from a Greek word, meaning "large-eyed."

DESCRIPTION,
M. thissoides-(Block and schneider-Cunther.)-Tarpum. - Uniform brilliant silvery; back darker. Body elongate, compressed, little elevated. Head 4 in length, depth $34-5$. D. 12 ; A. 20; Lat I, 42 ; B. 23. Dorsal filament longer than head. Atlantic ocean, entering fresh water; common on our Southern coasts, 



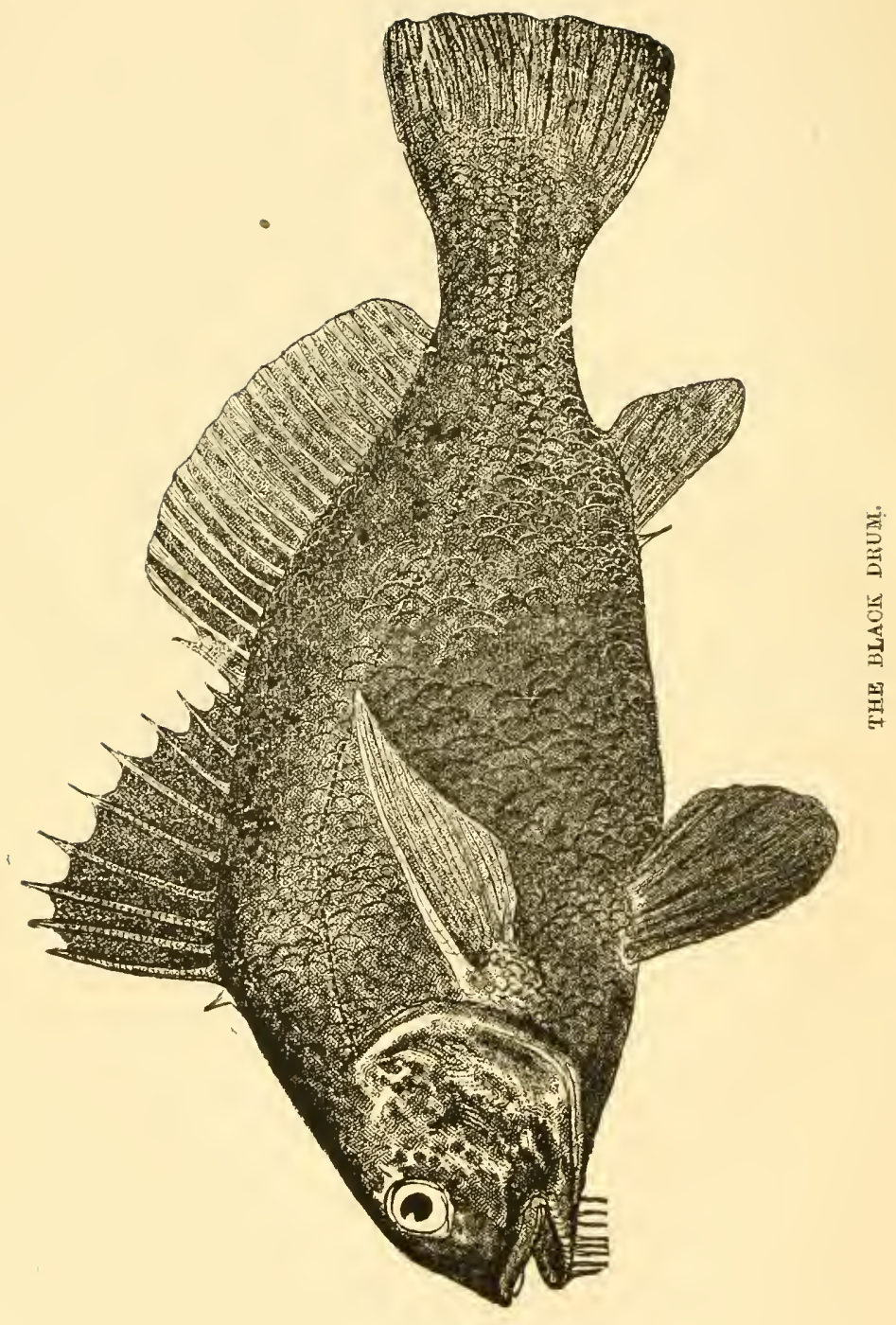




\section{CHAPTER VIII.}

The Droy. - The Hogrisa, or Pigfish. -The Satzor's Chorce.

Drux. - Pogonias chromis - (Linn). - Fishermen believe that there are two species of drum on the Floriala coast, one large and light colored, weighing up to seventy-tive or eighty pounds, the other dark colored and smaller, weighing from three pounds to ten, the larger being much the better fish. Professors Jordan and Gilbert only describe one species, so that the smaller is probably the young fish. We find these latter associating with the sheepshead, which they much resemble in appearance and habits, feed on the same mollusks, and are taken with the same bait. The large ones, say from twenty to forty pounds weight, appear in April or May in large schools in the bays and rivers, announcing their presence by the peculiar grunting or drumming noise which they make under the water, which ean be heard a long distance, though it is difficult to locate the sound. These big drum are taken with, strong hand lines, usually at night, with a whole crab upon the hook. Of course a fish of forty pounds can make a strong resistance. It is a dead pull between fisherman and fish. In St. Augustine the large drum is considered a good fish, and sells well. Where fish are more abundant and various, as at Halifax or Indian River Inlets, no one eats drum. To my taste, the flesh is rather coarse, but of good flavor. The smaller ones, which are often taken while rod fishing, make a strong fight, sirnilar to a sheepshead, surging to the 
bottom, and throwing their weight on the rod and line, one of which as liable, in the hands of an inexperienced angler, to be broken.

JORDAN AND GILBERT'S DESCRIPTION,

$P$ chromis-(Linn)-Drum,-Grayish silvery, with four or five dark vertical bars, which disappear with age ; fins dusky ; body oblong, much compressed ; profile very steep. its curve uneaven; ventral outline little curved. Moul moderate. maxillary scarcely reaching middle of orbit. Scales large, those on breast much smaller. Fins large, pectorals reaching beyond tips of ventrals, nearly to vent : second anal and spinal more than half length of head. Head above scaly, except a triangular space on snout. Head $3 \mathrm{I}-4$ in length; depth $2 \frac{1}{2}$. D. X, 20; A. II, 6; Lat, I. 50. Cape Cod to West Indies; abundant southward

HoG-FISI-Pig-FisH-perhaps Lachnolemus falcatus of Jordan and Gilbert's Synopsis. At any rate a fish of fine quality, rich and delicate. At Halifax Inlet it usually weighs about a pound, and in some seasons quite abundant, in others rare. It gives good sport on a rod, takes mullet bait and is found in deep channels. Color grayish ; profile steep, form compressed; teeth projecting similar to those of the sheepshead.

Sallor's Choice-Pomadasys fulvomaculatus-(Mitchell). Are excellent pan tish, very abundant in the bays and sounds of Florida; in size from two ounces to a pound. Resembles in form the scup of Northern waters. A very strong and active fish for its size, making fine play on a light rod. The Synopsis gives it a length of one foot, which is double the size of any that I have seen.

\section{JORDAN'S DESCRIPTION,}

Light brown, silvery below, sides with numerous orange colored and yellow spots ; those above the lateral line in oblique lines, those below in horizontal rows; vertical fins with similar spots; head blueish with yellow spots; angle of mouth and gill membranes with orange. Body oblong, compressed, not much elevated. Head long; snout conic ; mouth low and small, the maxillary hardly reaching to the nostrils; outer teeth slender and rather short; eye high, $4 \frac{1}{2}$ in head, nearly midway in its length. Dorsal and anal entirely naked, with a sheath of scales at base; anterior spines of, Horsal higher than the posterior; spines, graduated; pectoral moderate. Head $3 \frac{1}{2}$; depth 3 . D. XII., I6; A. III., I2 ; Lat. I. 75. L. T foot. Atlantic coast from New York southward-a food fish of some importance. 


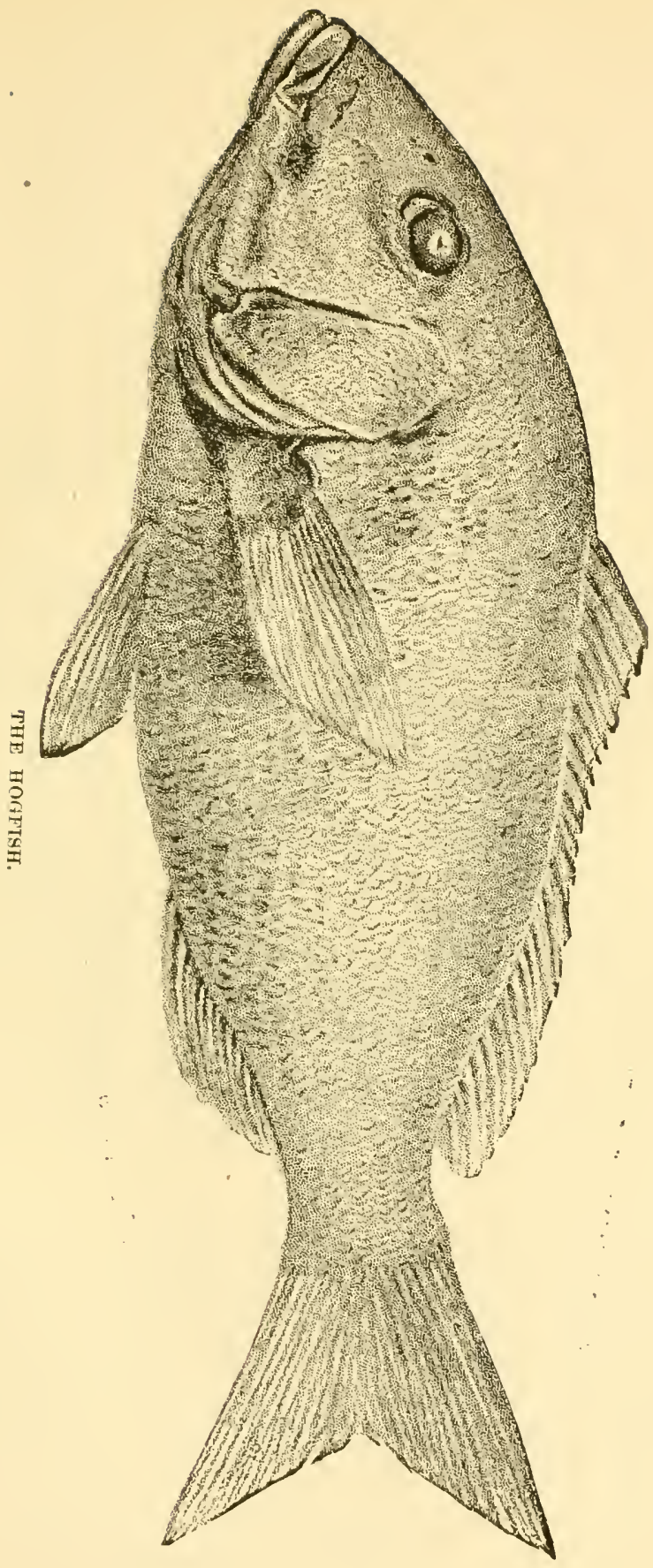





\section{C'HAPTER IX.}

The Salt Water Cateisa.-The Conger Eel.-The Silver, or White Mullet.-The Yellowtai, or Silfer Perch.

Salt Water Catfish-Gaff Topsall.-Alurehthys murinus -(Mitchell).-This may be set down as a game fish, being strong, active, and enduring in fight. Its play is much like that of the channel bass or redfish of the same waters, and it takes the same baits. In the spring it comes into the inlets and bays in great numbers, and becomes rather a nuisance to the angler, being an unpleasant fish to handle on account of its slimy covering, which besmears the hands and the tackle, and its long barbed pectoral spines inflict painful wounds on the incautious angler. It is a handsomely formed fish, with a forked tail, long dorsal fin, and barbels depending from the mouth. Color steel blue above, below silvery; from three to ten pounds in weight. . Flesh white and firm, and well-flavored, as I have found from experiment, though it is not often eaten. The eggs of this species are golden yellow, and of the size of grapes, which they much resemble, in bunches of ten or twelve. The fishermen say that this cattish carries its young, when hatched, in its moath.

Conger Eel-Murana ocellata-(Agassiz).-I have never seen the common eel on the Florida coast, but the conger is found in certain localities. If one goes near nightfall or on a dark lowery day to a certain deep channel about a mile from the mouth of the Halifax River, he may capture one or more of these ferocious fishes. At the breaking out of the Secession war there was at this place 
a quantity of live oak timber belonging to the Urited States governinent. Some of this was burned by the Confederates, and the rest of it thrown into the river, where it still lies on the bottom, affording hiding places for groupurs and conger eels.

The angler who has with difficulty played one of these congers, weighing from four to ten pomids, and got him alongside the boat, will find that he has caught a Tartar. The conger has an immense mouth, filled with long and sharp teeth, and if you turn him loose in the boat he comes at you open-mouthed, like a mad dog. I know that the first ore I canght would have driven Pacetti and myself overboard if he had not luckily disabled it with an oar. After that, P. always held the conger outside the boat with a gaff hook, while he cut off its head with a big knife. IVe got five of them that day, weighing from four to eight pounds, and when we took them home, although the meat looked white and delicate, the good woman of the house declined to cook them, saying that she "had no nse for snakes."

In early times in England, the conger was considered a delicacy, and history tells us that one of the English Kings died of a surfeit of this fish.

Molldet-Mugil lineatus-(Cnv. and Val.) -Silver or white mullet--M. brasiliensis-( $\mathrm{Ag}$.) - Although the mullet is not a game fish, yet being indispensable to the angler as bait, it should find a place among the game fishes.

All along the Southern coast, in the inlets, bays and rivers, the mullet is found in immense numbers, and being mostly in shallow water, is easily captured with the cast net, an implement so useful to the coast people that they could scarcely live withont it. Its use requires some strength of arm and considerable skill and practice; with it a man can almost always procure a mess of fish-not always, for in a cold norther all fish will betake themselves to deep water, where the cast net is useless.

In winter the mullet is small and ill-flavored for human fond, though it is always good for fish bait; but in summer and fall it is large, fat, and so well flavored as to be the favorite food fish of the natives. At this season it is salted and packed for winter use for 


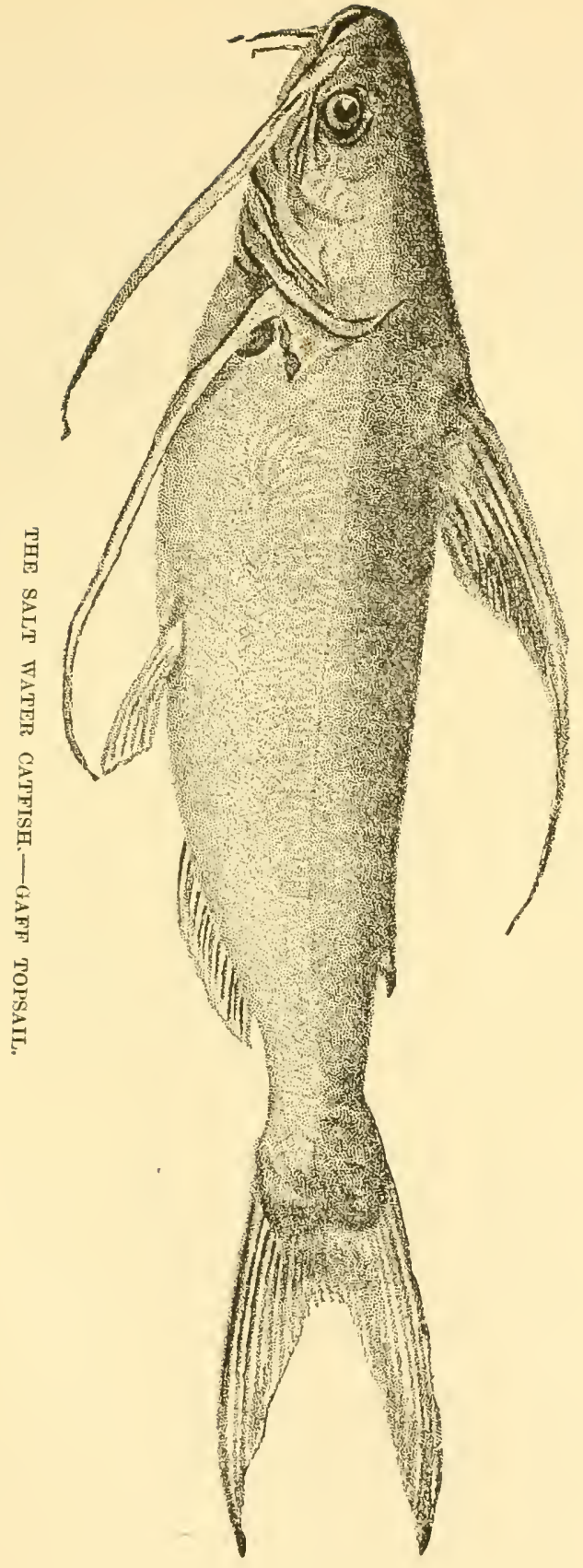



the people of the interior, taking salt well, and being as a pickled fish next in value to the mackerel, though at some distance behind. The roe of the mullet being salted, dried and smoked, is a rich and palatable food. The muliet has a gizzard-like organ for grinding up the small crustacea and mollusks which it takes into its stomach with the mud, which seems to be its principal food. Itself is the food of all carniverous fishes and birds, as well as of mankind, so that but for being a very prolific species, it would be in danger of extermination. Size, from half a pound to six pounds.

If, as it has been affirmed, the mullet will sometimes rise to a fly, it might give good sport, being a strong and active fish, capable of leaping out of the water like a tront.

In engaging boatmen and guides for Florida waters, it is important to select those who can use a cast net. I knew a party of anglers from Canada who came to camp out in southern Florida one winter, who, negleeting this qualification, found their trip a failure -they could get no bait.

JORDAN AND GILBERT'S DESCRIPTION.

Mugil albula-Striped mullet - Body rather elongate, little compressed, sub-. terete; snout not broad, moderately depressed; mouth moderate, lips thin, the maxillary ıot covered by the preorbital; angle made by the dentary bones obtuse, or nearly at a right angle. Scales comparatively small, a few on the dorsal and anal fins. Pectoral fins placed little above the axis of the body. Coloration dark blueish above, sides silvery, with conspicuous darker lateral stripes; a dusky blotch at base of pectorals. Ifead 4 I-3; depth 4 ; D. IV.I, 8 ; A III, 8 ; scales 42 -r 3 . Atlantic coast of the United States; very abundant southward, where it is much valued as a food fish.

Yellow-tan-Silver Perch-Sicirence punctatr--(Tinn.)-This is a pretty little fish, quite abundant in some parts of the Florida coast, which affords good sport on a light rod, and is a well-flavored pan-fish. In Halifax River it seldom weighs half a pound. Color greenish above, be]ow silvery; tail yellowish. 3

Besides the above described spevis, which belong to Southern waters, we find on the Florida const in winter some species which 
go North in summer, such as the sheepshead, bluefish, kingfish, or whiting, blackfish, and Lafayette, or spot-all abundant, but of small size. Sheepshcad, from half a pound to six pounds, can be taken in numbers which would astonish a New York angler-say from twenty to fifty in a tide, and they afford good sport on a rod with clams or crabs for bait. Bluefish from two ounces to two pounds in weight are sometimes abundant, the same ferocious, snapping, greedy fish which on the Northern coast affords so much sport to the fisherman, and which chops up such multitudes of small fish. Blackfish seldom go over a pound, but are abundant, an l " excellent meat," as father Walton says. Whiting run from three ounces to a pound, and afford fine sport with light tackle, being a very strong and active fish. The Lafayette, or spot, is abundant but small-average four ounces. All this seems to show that these species are hatched in Southern waters; and go North in summer to feed and grow.

- In addition to these valuable food and game fishes, we encounter others which might be called the obstructive, or dangerous speciesthose which destroy our tackle and give us trouble and annoyance. Such are the sharks, the rays, the sawfishes and the congers. 


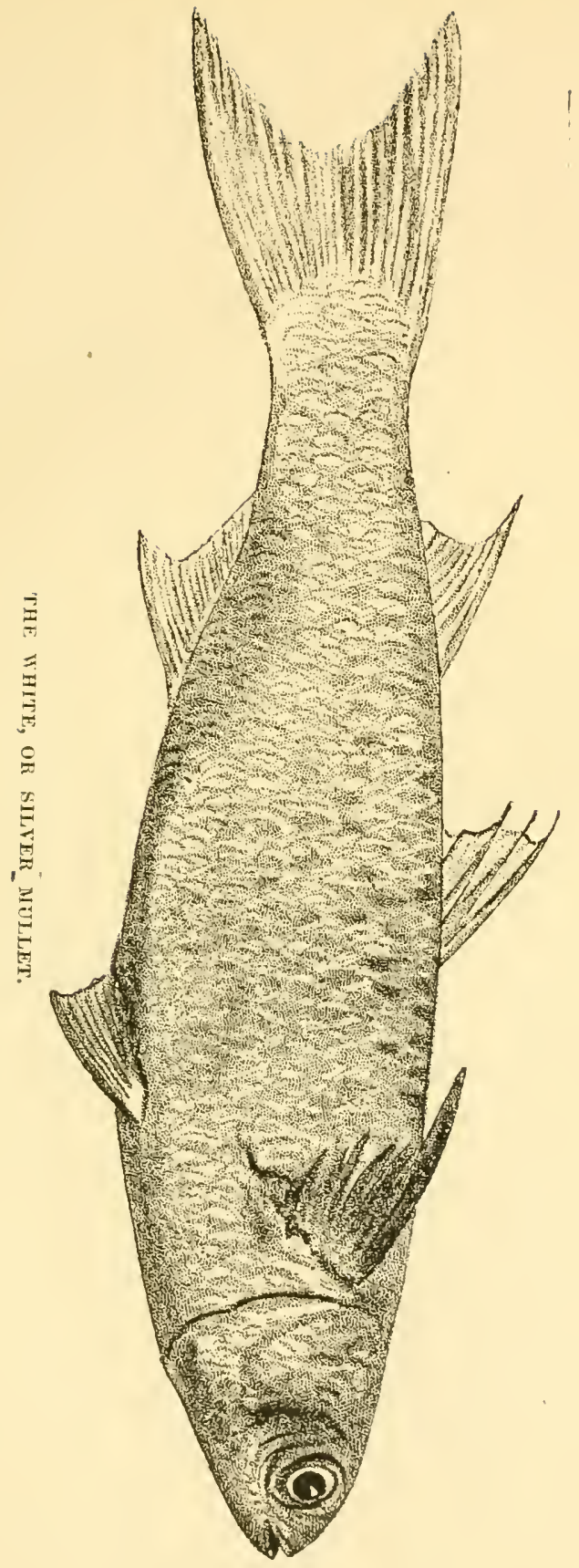





\section{CHAP'TER X.}

The Sharks.-The Sawfish.

Shanks.- Several species are fumd on the Florida coast; the common brown, or dusky shark, the shovel-nose, the hammer-head, the sand shark, the nurse shark. In warm weather most of these are abundant, ferocious and troublesome. They cannot bear eold weather, and it sometimes happens in the spring, when a warm spell has brought the sharks from the Gulf Stream to the eoast that a sud. den fall in the temperature destroys many of these delicate monsters. The common brown shark grows to the length of eight or nine feet, and destroys great quantities of fish. When abundant, they, like the wolves, take courage from their numbers, and become bold and aggressive, although usually they are cowardly for creatures of their size and strength. At such times they will take large bass and other fish away from the angler as he plays them. They are sure to take the bait if they see it, and when hooked the shark takes a turn near the surface, and usually cuts off the hook, unless it is fixed where the teeth eannot touch it. In that ease a shark of good cize can be played and killed on a rod. I have killed several of five feet long, and they did not make so long a fight as a red bass of half that size. I once killed a shark five feet long weighing perhaps fifty pounds, in half an hour; when gaffed it was found to be hooked on the outside, near the pectoral fin ; so that the fish could exert all its strength. When catching red bass on the sand shoals near the Inlet, I have known the sharks to collect abont the boat in such 
numbers, and become so bold, thas we thought it prudent to change our ground. When a captured shark is brought alongside the boat be will sometimes show fight, and bite a piece out of the planks of the boat's side. He is easily killed by a blow on the head with a club, or with a pistol ball in the same place. I have occasionally gone out shark-fishing with strangers who have a curiosity to see that sport. We go towards night to some sand-bank on the channel, and near the Inlet, drive a stont stake into the sand, to which we attach the end of a half-inch rope 100 feet long, armed with a big book and four or five feet of chain. 'This hook baited with a three pound fish is taken with a boat and dropped in the channel; the line is coiled up on the shore, and we wait for results. When a shark finds the bait, which may be in ten minutes, or an hour, the line slowly moves off; when time is given for swallowing the bait, (there is no nibbling in this kind of fishing) we give a strong pull to fasten the hook, and all hands lay hold of the line to bring the captive to the shore. The sport is lively for a few minutes, as a shark of eight feet long will drag three or four men to the water's edge, when we have to give him line. Ten minutes of this work will tire the shark, which is dragged ashore and knocked in the head with an axe-but beware of the sweep of his tail, and trust not vourself near his head; either end of him is dangerous.

The first time I went shark fishing, we eaught seven, from six to sight feet long, in an hour's time. A man who was planting in that neighborhood came with a large boat and took them away for his compost heap. The lirers contain from one to three gallons of oil, excellent for leather dressing. B. C. Pacetti during the war made a business of catching sharks for their oil, which he sold to the tanners at one dollar per gallon. He had a windlass at the landing near his house, with which big reel he could handle a shark alone, or if too large, his wife could help him land the monster. He used to set his line at night, and usually found a shark on it in the morning, unless, as sometimes happened, a bigger shark would eat him u, all but the head. He once found in the stomach of a lirge shark, half of an alligator five or six feet long when loving - the 
shark's teeth had cut him in two, spite of his scale armor. What chance would a man have in those terrible jaws?

Fortunately, the sharks on this coast feed so freely on fish that they do not care to attack mankind. I have heard of no wellauthenticated instance of human beings eaten by them. The bodies of some drowned persons have disappeared, which may have been devoured by sharks, but there is no evidence of it. Mr. Pacetti, who has been among them all his life, and has caught hundreds of them with nets and hooks, tells me th it he was never attacked but once by a shark. He was fishing on the beach with a net in the night, and wading in the surf a shark seized him by the leg. Having thick canvass trousers on, he escaped unwounded, and he thought the shark hardly knew what it was he attacked. Never having seen, what is commonly aftirmed, that the shark must turn on his back to seize his prey, I asked Pacetti what his experience was in the matter. His reply was, "A shark lass hold like any other fish, and he would have to go hungry if he had to tma over to bite, - most any fish would get away from him."

Another question is, how large do they grow? I have seen in the Indian Ocean, a leopard shark fully twenty-five feet long and as wide as the ship's long boat. It kept about the ship on a calm day with smooth water, for some hours, but would not touch a bait, which was fortunate, for no tackle that we had on board would have held such a fish. The mate struck at it with a harpoon, which bounded off from the to'xh and elastic hide, and the shark left us. It was covered with light colored spots on a darker ground-a terrible looking creature, which could have swallowed an ox.

The Shovel-xose SHark is a much more active species; when hooked, it never stops to be played, but goes off like a locomotive, taking the tackle with it.

The Hammer-head, or Grovxd shaRk, is a strange looking creature, with the head set at right angles with the body; the eyes at the extreme points of the head, and the mouth underneath like other sharks. This species rarely appear on the surface of the water; it is said to be one of the most ferocious and dangerous of the shark 
family. I liave killed small ones of three feet long, on a rod. The Nurse Shark-Scyllium cirratum-(Cuv.) - This is a sluggish species of shark, reddish brown in color, eyes small, barbs depending from the mouth, teeth very small, but strong. I have seen notches bitten out of a knife by this fish, in cutting out a hook; lives on the bottom, and when it takes a hook gives no play at all, but bangs like a dearl weight. From five to ten feet long, according to Professor Jordan, and inhabits warm latitudes.

Sawfise.-Pristis antiquorum-(Latham.) - Belongs to the Selachians, or shark family, and resembles a shark in form and arrangement of fins, with a long bony protuberance extending from the upper jaw. This is about one-quarter to one third the length of the tish; has at short intervals sharp spines projecting from each side, like the teeth of a comb, making a fearful weapon, with which the saw-fish strikes and kills its prey, consisting of mullet and other fish. The month is large and toothless, and is situated, like the shark's, beneath the snout.; into this the fish which are killed by the saw are received. It is sluggish, lying usually on the bottom, waiting for its prey, and when disturbed by a passing boat will, if of large size, strike powerful and dangerous blows with the saw, which has a lateral motion.

Between the saw-fish and the shark are frequent battles, and as the latter is very fond of its cousin, the saw is often found on the beach, the wearer having been devoured. This species grows to the length of fifteen feet, and are then formidable to encounter. The liver contains much oil, for which the saw-fish is sometimes harpooned I have taken the smaller specimens of three or four feet long with rod and reel; they take the bait quietly, so that you thmk your hook is fast to the bottom; after long pulling, up comes first a savage looking saw, striking right and left. To disable this fish strike it a heavy blow with a club at the junction of the saw with the head; by this it is paralyzed and can be handled with impunity. The islanders of the Pacific ocean mount this saw upon a handle and use it for a sword. 


\title{
CHAPTER XI.
}

\author{
The Rars.
}

To the class of Selachians the rays also belong, and many species of them are found on the Florida coast, from the enormous devilfish, which reaches a width of eighteen or twenty feet, to the little sikate, or old maid, one font in length.

- That which we principally meet with, the stingray, although not properly a game fish, yet as it often affords the angler considerable sport, although involuntarily, we must include it in our list, and under the name of stingray, stingaree, or clim-cracker-Dasyatis centrumus-(Mitchell.) It is thus described: "Disk a little broader than long, its anterior angle obtuse. Tail relatively stout, about one-third longer than the disk. Width of mouth about half its distance from the tip of the snout. Caudal spine one and a-half times width of mouth. Spiracles very large. Color uniform brownish. Length eight feet."--.Tordan and Gilbert's Synopsis.

To this I should add that the stingray has a pavement of enam. bled teeth, with which it can crush clams or oysters, and a bone five or six inches long attached to the tail, one-third the distance from its extremity; this bone is barbed like a fish-hook along its sides, and can be erected or depressed by the fish. When the ray strikes its enemy it draws the long whip-like tall aross the object, the bone eears through the flesh making a fearful wound, the danger of which seems to be aggravated by the poisonous nature of a black slimy matter which corers the bone; however this may be, the wound is exeremely painful, and very dangerous, often producing 
lockjaw. The fishermen dread the stingray, and with reason, . s it is often found lying on the flats and san bars, where the net is cast, My friend Pacetti has been several times struck by the rays, and onco he came near losing his leg from the wound.

In fishing for bass and sheepshead the angler will sometimes find his hook apparently fast to the bottom, and on pulling on it, the line will move slowly away with irresistible force-this for thirty or forty yards, when it will stop for ten or fifteen minutes and then move on again, in the same slow, resistless way, as if a yoke of oxen were hitched. If the angler wishes to kill the fish he must raise his anchor and follow wherever the ray may lead him. In this way, if the ray is of moderate size, say fifty or sixty pounds, he may in an liour's time bring his fish to the gaff. But this must not be attempted rashly, for as soon as the ray is touched with the gaff, it strikes an accurate blow with its long whip towards the gaffer. The staff, or bandle should be four or five feet long, and the arm that holds it strong, otherwise it will be wrenched from its grasp. If the boatman understands his business he will "insert the gaff near the head of the ray and quickly turn the fish upon its back alongside the boat, then with a heavy and sharp knife stab the ray several times in the throat. If properly done, the blood will gush forth as if with the strokes of a pump and quickly exhanst the powers of the fish. When dead, if the sting is wanted for a trophy, tow the carcass to the shore and cut off the tail, which much resembles one of those long black leather eovered waggon whips, used in the Sonth. Set the carcass adrift on the tide, and if there has not been a shark seen that day, in five minutes two or three of those ugly brutes will be tugging and tearing at the carcass of their cousin, the ray. Theie is no better bait for a shark than a chunk from a ray's fin; and indeed the flesh is white and delicate in appearance, and is considered a delicac? by many nations less fastidious than Americans. The principal food of the ray is shell-fish, and I have often seen it when dying vomit forth a pint or more of small mollusks.

I once hooked a ray up the river about half a mile from bome and undertook to drive it to the landing. It towed me about the river 
for an hour, and I had got my team well in hand, when it sulked and stopped on the bottom. The boatman would punch it with a pole and start it again. Finally it got the boat into deep water where the fule conld noc reach it, and as we lay there anchored in the channel is schooner came up the river before the wind, and to avoid being. lun down we harl to cut loose from our fish.

New-comers to Florida, and especially those frow the West, who has never seen anything larger than a eatfish or pickerel, are at first mnch interested in the capture of sharks and rays, but after a while the sport loses its zest, and we are glad to cut loose from these unmanageable monsters, with as little loss of time and tackle as may be.

The largest stingray I ever saw captured was taken by a young native fisherman of twelve years old, with a hand line. It was ten and a-half feet long, and must have weighed 150 pounds. I have killed them of sixty or seventy pounds, on a rod.

The whipray, or eagleray-Raia aquila-(Linn.)-Is about the same size as the stingray. but a much more active fish. When booked it is impossible to eheck it at all- -away goes fish and tackle. It is often seen sporting on the surface and leaping from the water: Tail very long and slender. Food like that of other rays, principally mollusks. It also goes by the name of clam-eraeker; is much less abundant than the stingray. 


\section{CHAPTER XII.}

\section{TARPLIITARPON-SILVER KING. [Megalops thrissoides.] \\ $13 \mathrm{Y}$ AL, FREGCO.}

For life I can't help scribbling once a week

liring old readers, nor discovering new,

In youth I wrote because my mind was full

And now because I feel it growing dull.

But " why then publish ?"-There are no rewards

Of fame or profit when the world grows weary,

I ask in turn,-why do we play at cards?

Why fish? Why read ?-To make the hours less dreary.

In journals devoted to sports of forest and stream, we frequently notice references to the lordly salmon, the noble striped bass, the plucky "bronze backers," and the speckled beanties-but the tarpon, "the Noblest Roman" of them all-the game fish par excellence of American waters is seldom noticed. When the acrobatic performances, and the fighting qualities of this noble fish become known, a new revoluiion will preseut itself to those who can enjoy true piscatorial sport. In a recent communication published in sne of your contemporaries, that accomplished writer "S. C. C." referred to the fighting qualities of the tarpon; and in writing comparative- 
Iy of like qualities in the salmon, black bass, striped bass and brook trout, he rated the first at five and the four latter at one.

'This fish is common in Florida, its habitat extending from Texas to the Georgia line, and possibly further north. At the mouth of the St. Johns River it is known as the jew fish; at some points as the silver tish. By Captain Romans, the orthography used was tarpum, and this has been adopted by "S. C. C;" and I find it spelled tarpum in the report of the United States Fish Commission for 1880. This fisl is very common on the South West Coast of Florida where it is known as tarpon. It was deemed advisable to change the name of Salt Spring, a tributary of the Anclote River, and owing to the great number of this fish visiting it, it has been named Tarpon Spring. The authority for the use of the word tarpum is as old as Captain Romans; but, in my wanderngs in this State, I found the fish called tarpon and not tarpum, and I use the former term, elaiming tinat the most common name in use should be adupted.

In its habits, the tarpon differs in different localities. In the St. Johns River they put in an appearance in Jine, and leave in October, for warmer waters and pastures new. It is probable that they follow the coast line to the southward in the autumn, and winter among the Floricla Fieys. They can be found at all seasons in the streams of the scutheist and southwest portions of the State. A friend who spent the last two winters collecting in Estero Bay, informed me that they cntered the bay on the flood and left it on the ebb tide. In many of the streams of Southwest Florida, they seem to be residents, and do not visit the lower and salty portions. A majority oi these fish, slmmering in the St. Johns Rirer, enter the stream on the flood, and leave it on the ebb tide, probably spending a short time between the tides, abont the bar or the shoals at the mouth of the river. Mile Point one mile above Mayport, Shell Bank below Mount Caroline, and the Back Channel east of Dames Point Light, seem to be favorite haunts of the tarpon, that do not leave the river on the ebb ule.

On one occasion, I was anchored over-night near Mile Point, and an immense number of moss bunkers had collected in the eddy astern of my boat. It appeared to me that hundreds of tarpon had gather- 
ed and resolved upon the destruction of the bunkers. At ajout 10 P. M., the tarpon commenced jumping and slashing, and the noise made by the fish prevented me from sleeping. Midnight arrived, and as "Nature's sweet restorer, balmy sleep" would not visit me, I baited my tarpon line, and permitted my bait to float with the tide to the point where the vaulter's were feeding: I, like "putience seated on a monument," fished and waited ; but as I could not secure a bite, I retired to my blankets at $2.30 \mathrm{~A}$. 3 ., and if not a wiser, I was a nadder man than at turning in time the previous evening.

In many of the streams of the sonthwest coast there exist broarl and shallow reaches of water, the bottom being covered with a dense growth of grass. The tarpon enter the grass, and approach the shore as closely as possible without exposing their backs, their object being apparently to bask in the sunshine. If a boat should approach elose enongh to disturb them, they rush for the deep water with lightning like rapidity. This peculiar trait, I have more especially noticed on the Hom'sassa River, and at Gordan's pass and Lagoon. 'This practice of "laying up," I have not noticed on the St. John's River. In some of the streams of Sonth Floridia they seem to live in fresh water, as in the upper portions of the Ilomosassa, Calloosahatchee, Rogers, and Harneys Rivers. On the Calloosahatchee, above the islands, the water is scarcely brackish, and at this point, these fish exist in inmense numbers. When I ascended this stream in 1875 , at the point referred to, the fish were so plentiful that one or more could be seen breaking the water at all times. To the fisherman who has been accustomed to the depopulated streams of the north, this may seem a "fish story," but unles they visit the streams of South Florida, they cannot form the faintest idea of the immense quantity of fish to be found in that section.

In ontline, the tarpon somewhat resembles a striped bass. It is covered with large ivory-like scales; about one-third of the surface of each scale being ormamented with a coating resembling frosted silver. One of the smaller scales in the way of a piscatorial visiting card I inclose for the inspection of the editor.

I enquired of many persons if this fish was edible, and could not obtain any information. Possessing ichthyophagons tendencies, in 
July last I resolved upon determining this matter and eut some steaks from a specimen weighing 128 pounds. I had them fried, and upon testing them I arrived at the conelusion, that as an edible fish the tarpon rates next to the pompano. To me it resembles a spring chicken in flavor. Several gentlemen tasted the fish and confirmed my opinion. Since that time the flesh of this fish has been sold in this market at ten cents per pound. The flesh is very tender and of a light walnut tint. To many the color of the flesh would be an objection.

As a vaniter the tarpon is unequalled, and his aerial feats "must be seen to be appreciated." On one occasion my friend G. and a companion, were rowing through Salt River (a tributary of the Homosassa) in a sixteen-foot Whitehall boat. A tarpon was sunning himself in the grass, and being disturbed made for deep water. Finding the water shallow, and the boat in the way, he endeavored to clear it at an angle. The head of the fish came in contact with the side of G's companion, which contact deflected him from his course, and he passed under one of the boat seats. A pocket knife was used to "settle his hash," but it would not penetrate the ivory-like armor of the fish. Oars were used to dispatch the prisoner, but it was found that if he was interiered with the boat wonld suffer from the vigorous blows of his head and tail. G. seated himself in the stern, and his companion in the bow and for the nonce the fish was awarded the post of honor unmolested. When peave was deelared, the gentlemen r'sumed their oars, but the one who deflected the silver king in his course, found that he could not "paddle his own canoe," for several of his ribs were fractured. G. rowed the boat to Jones, Landing on the Homosassa, and the tarpon was weighed, tipping the scales at 153 pounds. Some of your readers will probably pronounce this a "fish story," but if they conld see a tarpon rush throngh the water, and form a just estimate of the momentum of a moving fish of this weight, they would uot question the correctness of the above statement.

Several years since, the side wheel river steamer Water Lily was en route from Jacksonville to Mayport. The eaptain was seated on a chair in the centre of the forward deck, with his back to the for- 
ward house. As the boat was passing St. Johns Bluff, a small frisky tarpon leaped from the water, cleared the guards, and landed in the eaptain's lap. The juvenile vaulter was secured, and weighed sixty-eight pounds, being the smallest specimen that has been captured in this river to my knowledge.

About a year since a party was sailing a boat in Clear Water Harbor, and a froliesome tarpon amused himself by jumping over the boat, and in his course stuek above the boom, and in an instant the old sail was in tatters.

Some years since a man was fishing for channel bass, in an ancient slug out near the mouth of Trout Creek, a tributary of the St. Johns River. A jovial tarpon vaulted in the air, landed in the canoe, and the bottom was knocked out of the machine. 'The fish escaped, the fisherman caught a ducking, and was rescued by parties anchored near by.

When in a vaulting mood, I have hundreds of times seen large tarpon clear the water with their tails from one to four feet. On one occasion my friend $P$. was fishing at Mile Point and a large frisky tarpon jumped near bis boat, rounded the sand bar and repeated his aerial feats fifteen times. In Sept. '81 I was fishing at the same point for these fish, using a large cork float, for tackle a gang of large Virginia hooks, and for bait two halves of a mullet. The float disappeared, and instantly there appeared in the air, the large'st tarpon $I$ ever saw. Ife left the water at an angle, and, as imprubable as it may appear to the uninterested, he landed at least twenty feet from where he left his native element. Whilst in the air he opened his eapacions month, shook his head like a terrier shaking a rat, and my gang of hooks went flying through the air. On many oecasions I have had these fish seize my bait and run with lightning like rapidity for twenty or a hundred yards, then leap into the air, slake their hears and expel the bait.

It has been my lot to eapture many varietics of fish in various portions of the United States, and in different oceans of this world, but I never found anything to even approach the lightning-iike dashes of the tarpon. On one occasion my frlenc b. wiw ansung opposite the old Light House at Mayport for channnc lass. Bites 
were few and far between, and $B$. reclined backwards on the stern sheets of the boat holding the line between his finger and thumb. One of these fish seized his bait and started off, and before he could eiear his finger from the line it was cut to the bone. During the summer it is common to meet amateur fishermen on our streets, and they will exhibit their searred fingers and laughingly reply "I hooked him bnt be left."

For vaulting exploits tarpon cannot be equalled by anything inhabiting ocean or river. Among the colored people in the neighborhood of Tront creek they have the reputation of throwing sinkers at the fishermen, and when one of these gentry is fishing for channel bass, and hooks a tarpon, he reelines on the boat seat, and permits the silver king to vault and rush unmolested. The lead-throwing notion is the result of the jumping proclivities of this fish. Several years since, a representative of the colored persuasion booked a large one, and attempted to land him by "Scotch navigation." When the fish neared the boat, he went through one of his aerial periormances, and his head was high above the boat. 'The darkey kept a taut line; the hook tore ont; the traction of the fisherman caused the sinker to come in-board, and the darkey's pate came in contact with a heavy piece of lead. From information obtained I have reason to believe that in the southern portions of the State these fish vault in the air, when they are in a frolicsome mood; but in all my wanderings in that portion of the State I never witnessed the performance, but have frequently seen them break water like a bluefish.

'I'he capture of a tarpon with a hook and line is a difficult undertaking. Every summer many are hooked, but few are landed. During the past season in this section but five have been eaptured, the smallest weighing 125 and the largest 198 pounds, or an average of 147 pounds. We frequently read of the excitement attending the capture of a bronze backer or a speckled beanty, but those who give their experiences should hitch on to a tarpon, and they would discover "music in the air" worth recording; for the capture of a silver king is a bright spot in a fisherman's existence, and a fact worth referring to at a camp-fire.

The other day my friend Dr. Q. informed me that during one 
forenoon in August last, at Mile Point, he had ten tarpon bites and failed to land a fish. The inside of the mouth of this fish is like gutta-percha. The tongue resembles that of a calf, and with it they seem to eject the bait. The lower jaw points upwards, and on the upper are two moveable plates, armed with minute teeth. With these armed plates they seem to sut the line.

The tarpon takes the bait near the surface or at the bottom. At times, after taking the bait they will instantly appear in the air near the boat; and at others they will run with lightning-like rapidity for a long distance, and then indulge in their acrobatic performances. It seems that they hold the bait in their mouths, and when they jump and are in the air, shake their heads and ejeet the bait. It is a common thing for them to retain the bait until they jump, and to the astonishment of the fishermen when they reach the water the bait is clear and the fish is off at a tangent.

Over two years since I prepared a tackle which I fancied would circumvent the silvery beauties. I attached three of Job Johnson's No. 2 drum hooks to a stout cotton snood. I lapped the hooks one above the other, so that the snood was not exposed. I then passed the three hor,ks through a half mullet, and was rewarded with a bite. I "yanked," and the performance commenced. My line was 600 feet in length, and after a half hour's vaulting and lightninglike rushes the fish succumved. I requested the boatman to up anchor and row for shore. The fish quietly followed the boat, but before I reached the beach the snood was cut off with his scissor-like jaws. Upon examining my tackle I found that he had swallowed the bait, and the unprotected portion of the snood had been cut by the moveable maxillary plates of the fish.

'T'o give your readers some idea of the strength of the tarpon, I shall merely refer to two instances illustrative of their prowess. On one occasion I was fishing for channel bass, and McMillen, the boatman, requested permission to put out my tarpon line. I baited the gang of hooks mounted on piano wire. On a board was wound 700 feet of line. I requested MeMillen to unwind all the line and coil it on the bottom of the boat, and if he looked a fish, to pass the line to me. Very soon I saw a tarpon vault in the air, and on reach- 
ing the water ent and slash in an unusual manner. I yelled to Mac to "give him more iinn," and as my back was towards the boatman I could not understand why he did not obey instructions. I turned round and found that he had not unwrapped the line. He had braced his feet against a seat and had a death grip on the board on which the line was wrapped. The result was a beary cable laid cotton line parted.

Some years since several of my friends were casting in the surf at Pellican Island for channel bass. In the party was an ardent fish. erman, a boy of fourteen. To secure it, he had fastened one end of his line around his waist. He baited his hook and threw it as far as practicable from the shore, and hooked a fish. In-lintly the boy started for the coast of Africa, struggling and yelling. The gentlemen rushed into the surf, rescued the boy, and landed the piime moving power at the other end, which proved to be a tarpon weighing eighty-three pounds.

After testing various kinds of tackle, I have adopted a barbarous and possibly an unsportsmanlike rig for the capture of this noble tish. I take the heaviest piano wire obtainable, and make three joints, four inches long, and three, six inches in length. 'The joints of the links are made by beating the wire in the fire, bending each end, allowing half an inch for soldering. Before soldering, I polish each piece of wire with emery paper, and tin it to prevent rusting. 'To the upper link I attach a strong brass swivel two and one-half inches in length. I wrap the ends of the wire below the loops with tine copper wire, and finish the job with common solder. I nse hooks two inches from tip to shank. To each of the three lower links I solder two hooks at a right angle. When completed, the hooks are in two lines. For bait I cut a mullet in half from mouth to tail. I l'ass one hook through the eye, one amidships, and the other near the tail. Three hooks pass through the bait, with points exposed, and the three others pass beyond the edge of the bait. In addition, I taxe a packing needle and fine twine, and tie the links to the bait. By adopting this course I make an attractive and armored bait, with hooks lartially concealed, and an almost invisible snood. Tackle rigged in this way possesses great strength, for the last time I was 
fishing at Mayport I eaptured two sharks, one seven and the other nine feet in length, on my tarpon rig.

In August last, I was fishing near my friend P., and hooked a large tarpon, and after a long and exciting tussle the fish was dispused to yield. I requested $P$. to come on board and use the grains. IIe complied, and as I was eautiously bringing the silver beauty to the side of the boat the hooks tore out, and he settled to the bottom lıke a log. P. left me; I did not break a commandm nt, but seated myself in the coukpit of the boat, held my peace, filled my pipe and indulged in a smoke.

P. returned to his boat, and soon after shonted that he lad "made a discovery." I questioned him regarding it, but he told me "to wait and he would make a tackle to capture the artful dodgers." A few days later he visited me and exhibited "his new rig," which consisted of a dog chain two feet long. To the links of the chain he had fastened seven copper wire loops, and to each of the loops he soldered a hook. IIe proceeded to Mile Point, opened a large mullet from vent to gills, passed swivel end of chain out of mouth of bait, a.d to it attached his line. The balance of the chain he stowed away in the belly of the fish, leaving the points of the hooks protruding from the incision, and to keep everything in sitı he took a number of turns around the body of the fish with strong thread. The bait was appropriated by a tarpon, and during the head-shaking process the end of the chain escaped from its place of confinement, twitched about the fish's head, and the lower hook entered on the outside below the gills. After a struggle P. beached a tarpon weighing 125 pounds. An examination established the fact that one of the upper hooks had taken a slight hold in one lip, and had held long enough for the "skirmishing hook" to enter.

P. tried another experiment, that of attaching four piano wire snoods eighteen to twenty-four inches long, to a swivel, and to each snood was attached a large sized hook. He opened a mullet as above; passed swivel through mouth of bait, and stowed the hooks in belly leaving points exposed, and secured the hooks by wrapping bait with thread. He was rewarded with a bite, and landed a tarpon six feet 
eleven inches in length, weighing 198 pounds. It was found that one of the hooks had a slight hold in mouth, and that one of the "skirmishers" had switched round and entered the back of the fish below the head, and held him. Tarpon fishing is in its infancy, and we trust that some of your piseatorial experts will invent appropriate tackle, try tarpon fishing, and teach us greenhorns how to eapture $\imath^{\text {? }}$

Tarpon seem to confine themselves to a tish diet, and $I$ have yet to hear of one noticing a crab bait. The bait universally used is a portion of, or a whole, mullet. On one occasion my friend, Dr. F., was fishing for large-mouthed bass at the head of the Homosassa River, and as they would not rise to a fly, he used a minnow for bait. He soon ascertained that he had about six lineal feet of tarpon at the other end. At first the fish pard no attention to the traetion of a light split bamboo trout rod, but he ultimately started off at lightning speed, the reel humming as it never did before, and ti. Doctor was minus a leader. He rigged his line again, used a minnow as bait, made a cast, got a strike, and, to his astonishment and disgust, another tarpon had appropriated the bait, and in an instant he was minus his tackle. From that time to the present the Doetor has refrained from using minnows for bait where tarpon exist.

Nearly two years since your valued correspondent, "M.," was trolling with a spinner near Sannibal Island for channel bass, and toward evening he found that he had hooked a larger fish than he bargained for. After a tussle the fish was landed, and it proved to be a tarpon weighing thirty-eight pounds. Last summer, I had a large and strong spoon bait made by Hill \& Co., of Grand Rapids, Michigan. I only used it on two occasions but failed to secure a strike. Next summer I propose testing it again, for I feel assured that the silver king cannot resist such an attractive lure.

- The capture of the noble tarpon is worthy of the notice of experts, and if they wish an exciting experience, a new revelation, I would advise them to visit southeastern or southwestern portions of the State during the winter, or the lower St. Johns during August and September. If they should engage in tarpon fishing in this river, whilst waiting for a bite they can indulge in the capture of channel 
lass Weighing fron inenty to sixty pounds; or if they fish at the Jetties they can kill time by landing sheepshead, cavalli, sea troutl and medium-sized bass.

As yet, no one in this section except myself has attempted ine capture of a tarpon with a rod and reel; and thus far I have been so fortunate as not to hork one with this description of tackle. Anothe, summer, I will destroy several first-class heavy bass rods or capture one of the silve1 "rgs with rod, reel, and Cuttyhunk line.

Tarpon fishing will open a new field worthy of the notice of piscatorial experts. At present, this sport is in its infancy, but it is probable that the time will arrive, when we shall suceed in capturing the silver beauties in greater number than in the past. What is required for the suceessful eapture of these fish, is a double spring hook, eighteen inches in length, and so arranged that the hooks can be closed; a half mullet securely attached, and when the bait is interfered with, a eatch or ring shall be thisplaced and the hooks separated to a distance of at least eighteen inches. With such a rig, these fish can be eaptured ; and the question arises who will inven $t$ and make a spring hrok adapted to the capture of the silver kings. The southwest coast will soon be opened up by railroads and steam. boats, and, as many fishermen will visit that section, tackle for tar. pon fishing will be required and it shzuld be supplied.

As a game fish, the silver kings have no equal ; in their lightninglike dashes for liberty, they excel anything wearing scales, and as vaulers they cannot be equalled. I write eulogistically of the tarpon, for he and I have had more than one tussle. In an article in a recent number of a contemporary, a gentleman offered to pay for as excursion ticket to Florida, and three months hotel bill, to any ine who would land a tarpon with a rod and reel. My impression is, that the gentleman making the offer "Las been there," and hat his "fingers burnc." In Orvis and Cheney's new book entitled "Fishing with a fly," Dr. Henshall informs us that " the capture of the salmon is an epic poem, and the taking of the trout an idyl," but we opine that if he found a seven-foot tarpon on the end of his line and snceeded in landing the vaulter, that he would describe the operation as a tragic ¿ poem. 


\section{CHAP'TITI XIII.}

TIIE PISIINT: GROUNDS OF FLORIDA-TACKLE AND LIRES.

By Dr. C. J. Kenwosthy.-At Fresco.

In Florida, as elsewhere, almost any hotel and boarding-house keeper who resides near a creek, river or lake refers in laudatory terms to the fishing. The majority of such statements should be received cum grano salis. As a rule, good fishing cannot be secured near large cities or where fishermen use seines and cast nets.

Jacksonville is the objective and distributing point of the State, but fishing near by is poor, very poor. At the mouth of St. John's River 'twenty-five miles below Jacksonville, fair fishing can be secured. Ten days since my friend, Col. H., spent a day at this point. He used an eight-ounce split bamboo and landed 210 sea tront, bass and sheepshead. He fished again on Monday and landed sixty. On Friday last Arno and his partner (professional fishermen) canght, with Japan cane rods, 130 strings of fish, and on Saturday 110 strings. A "string" of fish in this market consists of one or more fish weighing about four pounds.

As yet no one has tried fly fishing for sea trout and channcl bass in the creeks emptying into the lower St. John's River, but we are of the opinion that they will seize the feathery lure as well as on the southwest coast. Fair accommodations can be obtained at Mayport and Pilot Town at two dollars per day or ten dollars per week. In some of the crecks tributary to the St. John's River, between Jacksonville and Sandford, bream, large-mouthed bass and pickerel can be caught in great numbers. In January and February the bass will take a spoon or fly. In the upper St. John's (above Enterprise) and 
its tributary streams and lakes, the fisherman will soon be surfeited in capturing large-mouthed bass. But as there are no hotels and boarding houses, and as the water is generally bounded by broad marshes, persons will be compelled to use a boat large enough for simping jurposes.

At St. Augustine there are a number of exeellent hotels, but the bising is poor when compared with streams further south. At New Smyrua the fishing is fair, and for further information I will refer be reader to the interesting articles in The Avgler by "S. C. C." At tlis point there is a new lotel and several boarding-houses; board from eight to sixteen dollars per week for permanent boarders.

Indian Ruve can be reached at Sand Point or Rock Ledge by steamers ou St. John's River, and a short trip overland. Twice each month Captain Ifenderson will make trips from this eity to Indian River with his new, comfortable and safe sharpie, sixty-five feet long and nearly fifteen tons measurement. I have not fished the Sower end of the Indian River, but from reliable information obtained from many friends I am eonvineed fishermen will not be disappointer if they visit this locality. If disappointed, it would be agreeably so in finding such a great variety of fish and in such immense rumbers. At Lake Worth, a few miles further south, in the lake or at the inlet, excellent fishing will be found. Fair accommodations wan be seenred at varions points on the river, but the best course that ean be adopted by fishermen would be the chartering of a sailboat, with a good captain, at Sand Point or Rock Ledge. This could be avoided by taking passage with Captain Henderson on his Sharpie. I have reason to believe that a steamboat is, or will soon be, running on the Indian River.

If a fisherman wishes to,capture large-mouthed bass until he is surfeited, let him visit Kessemmee City, secure a boat, descend the Kessemmee River, and he will isoon be surfeited with the "bigmonths." But if the angler expects to meet with the pluck and Gght of the small-mouthed bass of the North he will be mistaken.

If the fisherman is disposed to enjoy a sail and explore the interior of the State, let lim ship a suitable boat to Kessemmee City by steamboat and railroad; launch the boat, descend the Kessemmee 
Rivcr, skirt the southwest shore of Lake Ochechobee; enter and fass thiongh the canal to the Cullowahatchin River and descend this strcim to Charlotte Harbor.

In the streams along the coast between St. Marks and Cedar Keys the fisher will find a piscatorial incognito. The coast is shoal and can be navigated in a small boat. The streams are numerous, and excellent camping-grounds will be found on their banks. 'The shoals waters along the coast abound with ducks, the shores with beach birds, and the land with deer and turkeys. All the streams abound with black bass (southern trout), channel bass, cavalli, sheepshead, bream and sea trout. On these streams a fly rod would be found very useful. As the coast referred to is not inhabited, parties visiting it must provide for the imner man.

At Cedar Keys fair fishing c:in at times be obtained. On one oceasion during a forenoon I landed 383 pounds of sea trout at this point. Alfred Jones, formerly of Homosassa, has opened a house at Seale Key, distant two or three miles from Cedar Keys. At Cardigran's Reefs, a short row from the house, fair channel bass, sea trout, sheepshead and blackfish fishing can be secured. The able New York steamer Eliza Hancox, Captain Post, has been placed on the route between Cedar Keys and Tampa, and travelers will be pleased with the accommodations on this able boat.

IIomosassa, the sportsman's paradise, has been patronized in the past by hundreds, but the old building has been destroyed by fire 'The fishing is good, but Mother Jones' table and her clean soft beds are wanting. A new hotel has been erected at Anclote, and muck has been written about the salt water fishing at this point, but I must confess that I could not find the "superior" part of it. Lake Butler, a short distance from the hotel, affords good fishing for black bass. On several occasions I endeavored to find good fishing at Clear Water Iarbor, but failed. At St. John's Pass I found fair shominesting.

Much has been written about the superior fishing at Tampa B.r5 but I was disappointed. At the oyster bank off Point Gadsden, nius miles from Tampa, fair sheepshearling can be secured. At the mout of the Hillsboro River at 'Tampa, on the young flool, sheepshead 
and sea trout can be captured. When I fished at this spot, wind bait and tackle were wrong, and I failed to capture a seale. At the wreck of the steamor H. M. Cool, opposite the month of Old Tampa Bay, fair fishing, more especially for grouper, will be found.

At Long Boat Inlet, Sarasota Bay, good fishing will be found. At the mouth of Saracota Pass, ehannel bass and sheepshead can be captured. My friem Dr. Ferber informed me that he fished a pool in Billy Bow-Legs Creek (a tributary of this bay) and hooked cavalli on the fly at every east. Three years since a friend captured a great number of Spanish maekerel, trolling with a spoon, in Little Sarasota Bay. At Casey's Pass, the southerly outlet of the lastnamed bay, good sport can be obtained in the way of catching grouper, channel bass and sea tront.

South of Casey's Pass is Kettle Ifarbor, a point where sawfish do most congregate, and the piseator can amuse himself eatching the sawyers. In addition he will find quantum sufficit of sea tront and sheepshead. At Little Gasparilla Pass, Charlotte Harbor, the fishing will be found $A$. 1. On the young flood at the northerly point of Little Gasparilla Island, eavall, channel bass, sea trout, and bonefish ean be captured in immense numbers. At this pomt I lrave hooked these fish at every east and reeled them in mil my ams ached. Within twenty yards of the entrance will be fouml a bluff, shelly shore, which extends to the south for over a humberl yaris and at this place at any stage of tide sheepshead ranging from two to four pounds ean be landed as fast as hooks can be baited. Cruising about on the sand bar on the sontherly side of the pass I noticerl large channel bass. I waded out to where the watcr was kuer-kiecr, cast my bait near the fish, and instantly the musie would commonce In the centre of this island is a fresh water lagoon, where excellent drinking water can be obtained.

At any of the passes at Charlotte Harbor excellent fishing will be found. At Punta Rassa, which ean be reached by steamship from Cedar Keys, fair accommodations can be secured at the residence of the telegraph operator or at Jaeob Summerlin's house. 'The rlock at this point is the paradise of "sheepsheading." At this place your correspondent "M." landed fifty-six sheepshead in sixty minutes. This 
may be considered a "fish story," but to do away with the improbability I may remark that "MI." had a man to bait his lines and unhook the fish. Those who know "MI." will receive his statement unquestioned; but to doubters I will say that my friend Dr. Lewis of Philadelphia, stood by and timed our mutual friend "MI."

If the fisherman is disposed to try conclusions with large game, he can fish from the end of the dock and hitch on to large jewfish and shark. With a boat and spinner large numbers of channel bass can be captured by trolling. At this point "M." hooked on spoon bait and landed a juvenile tarpon weighing thirty-eight pounds.

By ascending the Calloosahatchie River above the islands the fisherman will reach the home of the cavalli and tarpon. If the fisher. man is disposed to lay the foundation for a camp-fire yarn, let him provide himself with a harpoon spear, 100 yards of whale line and a staunch boat. By keeping his eyes open he will see devil fish from fourteen to twenty feet in width sporting in the bay. They can be approached and harpooned. If struck the ball will open, and the occupants of the boat will enjoy a ride without raising an ashen breeze.

South of Punta Rassa is Estero Bay, where, in addition to the small fry previously referred tu, tarpon and sawfish revel in all their primitive ignorance of fishermen, steamboats and artificial baits. Those who visit this bay should not fail to ascend Corkscrew River and enjoy the fishing, and deer and turkey shooting. In this river tarpons, the silver kings, exist in countless numbers.

At Gorden's Pass twenty-eight miles south of Punta Rassa will be found a sportsman's paradise with fish galore; good oysters, ducks, beach birds, deer, and bear. South of this point to North Cape Sable any of the inlets, rivers, or creeks, will furnish unequalled piscatorial sport. From reliable information and actual observation, I have no hesitation in asserting that for number and variety of fish, the lower Indian River, and many points on the southwest coast of Florida excel any other portion of the world.

In many of the interior lakes large mouthed bass and bream exist in great numbers, but they afford but poor sport. After the first effort the former give up, and come in like a log of wood. In the 
lakes and streams of the central portion of the State, war-mouthed perch from one to three pounds will be found, and for fighting qualities they can be recommeniled. My only experience in fishing in the western portion of the State was at Apalachicola in 1844, when I captured my first channel bass ; at that time the fishing was excellent.

To properly enjoy fishing on the southwest coast, a party of from two to four should charter a small sloop or schooner of from five to six tons burthen at Cedar Keys. The cost of the craft will be from five to six dollars per day; and this will include the captain with man or boy, one small boat, stove, crockery, cooking utensils and bedding. Party chartering boat to provide provisions. If party consisted of four, the expense should not exceed ten dollars per day.

I cannot refrain from making a few remarks regarding fly fishing in Florida and will quote from my article published in "Fishing with the Fly."

"The votaries of the rod and recl have overlooked an important field for sport; for, in my opinion no portion of the United States offers such advantages for fly fishing as portions of Florida during the winter months. The health of the State is beyond cavil or dispute; the climate is all the most fastidions ean ask; there is almost

a total absence of insect pests, and last though not least, a greater variety of fish that will take the fly, than in any other section of the Union. My friend Dr. Ferber, on his return from the southwest coast in April last visited me, and stated that he had caught on that coast with artificial flies eleven distinct species of tish; and I can add five species, making sixteen which can be captured with the feathery lure."

"Instead of wading icy-cold and over fished brooks, tearing clothes and flesh creeping through briars and brush, and being subjected to the sanguinary attentions of the mosquitoes, and black flies, in l,ringing to crcel a few fingerlings, in Florida, the angler can cast his fly from a sandy beach or boat inhale an invigorating atmospherc, bask in the sunshine, and capture specimens of the 
finny tribe, the weight of which can be determined by pounds instead of ounces."

With regard to tackle, I may remark, that the game fish of Florida are unedueated, and make no distinction between a mistcolored leader and a clothes line. The great desideratum for Florida fishing is strength of tackle-stont lines and large hooks. A heavy bass rod is all important; if fly fishing is indulged in the rod should not be less than eight ounces. As the fish are not particular, expensive flies need not be used. On the sonthwest coast spoon bait are used to a great extent; I have tested many spoons and spinners, but those made by L. S. Hill \& Co. of Grand Rapid Mich. suit me best. These baits should be purchased from the manufacturers, and they be requested to add stronger hooks to the small sizes, and nstead of treble to apply donble hooks. For fishing in this State,

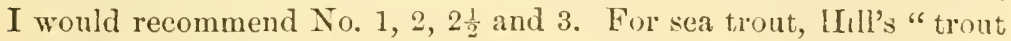
and bass fly" would be found an attractive bait. For hand-line fishing, resident experts, use cable laid cotton, and braided cotton lines. Unless for fly fishing strong and che.tp tackle is all that is required. Lines and hooks suitable for ordinary fishing can be purchased in this city. 


\section{ABBEY \& IMBRIE,}

Manufacturers of

\section{FINE FISHINGTACKLE}

\section{Maiden Lane, New York,}

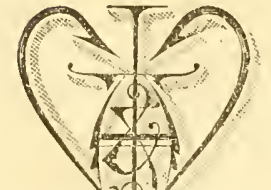

Particular attention given to the manufacture of $j$

RODS, REELS, LINES, Etc., For Coast Fishing.

BAMBOO AND GREENIIEAR' CHUII RODS,

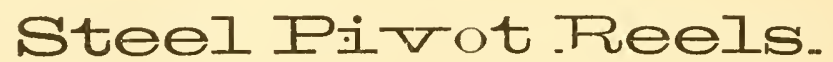

Fxtra Strong Gut, Hand Lines for

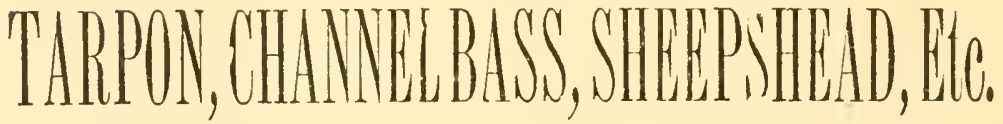

If your dealer does not keep our goods in stock or will not order them fo you, send us 50 cents for our I 20 page Illustrated Catalogue and Price List. 


\section{THOS. J. CONROY}

Manufacturer, Importer, Wholesale $\mathbb{S}$ Retail Dealer in

\section{FINE FISHING TACKLE,} 65 Fulton Street, New York.

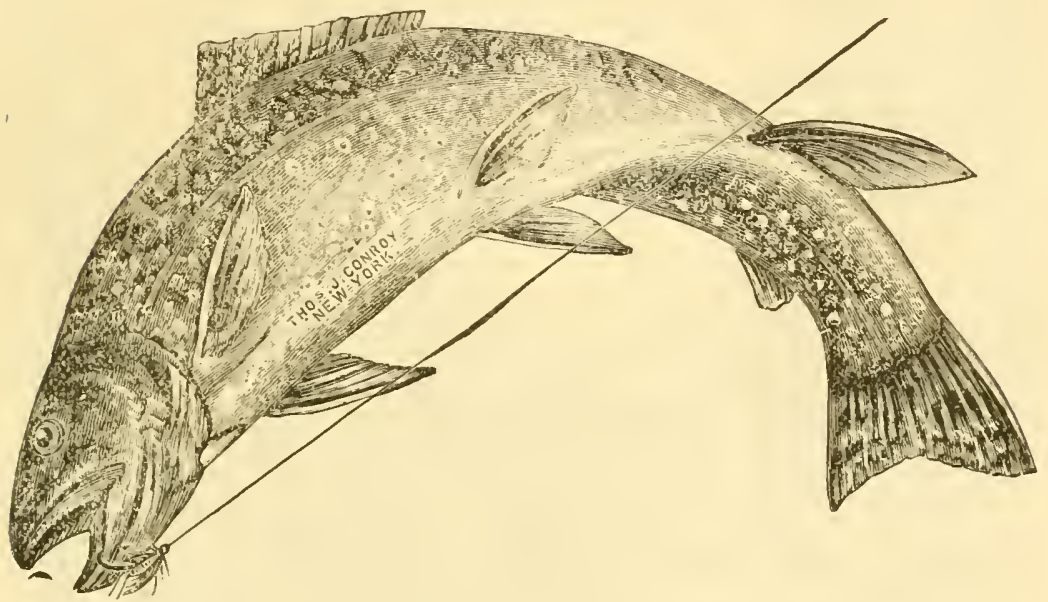

New Stylus of my Crelcirrted Hexagonal Bamboo kods. New patterns Steel Pivo ivultipluing Reels in Aluminium. Brass, German Silver and Rubber. "Cuttyhunk" Ree! Lines all length and sizes, Harrison's Celebrated Knobbed and Needle Eved (O'Shaughnessy Hooks. Hooks on Prass wire and Plain Wire Srells. Artificial Flies and Baits in Great variery and a large assortment of tackle of every description suitable for the Inland and Coast Fishing.

\section{SOLF AGENTS FOR}

\section{MITCHELL'S PATENT BUTT FLI RODS.}

Tents, Camp Cots, Canp Sinves, Jack Lamps, Tackle Cases, Etc.

My long experience in fitting ou' parties for Florida enables me from simply knowing the point s to be visited, to select such articles as are best adapted to the locations.

Send 15 cents for illustrated Catalogue and Hand Book of Fishng Tackle with supplement. 


\section{HENRY C. SQUTRES,}

WHOLESALE AND RETAIL DEALER IN

Guns, Fishing Tackle, Lawn Tenis, Pleasure Boals \& Canoes, AND EVERYTHING FOR THE FOREST, FIELD OR STREAM.

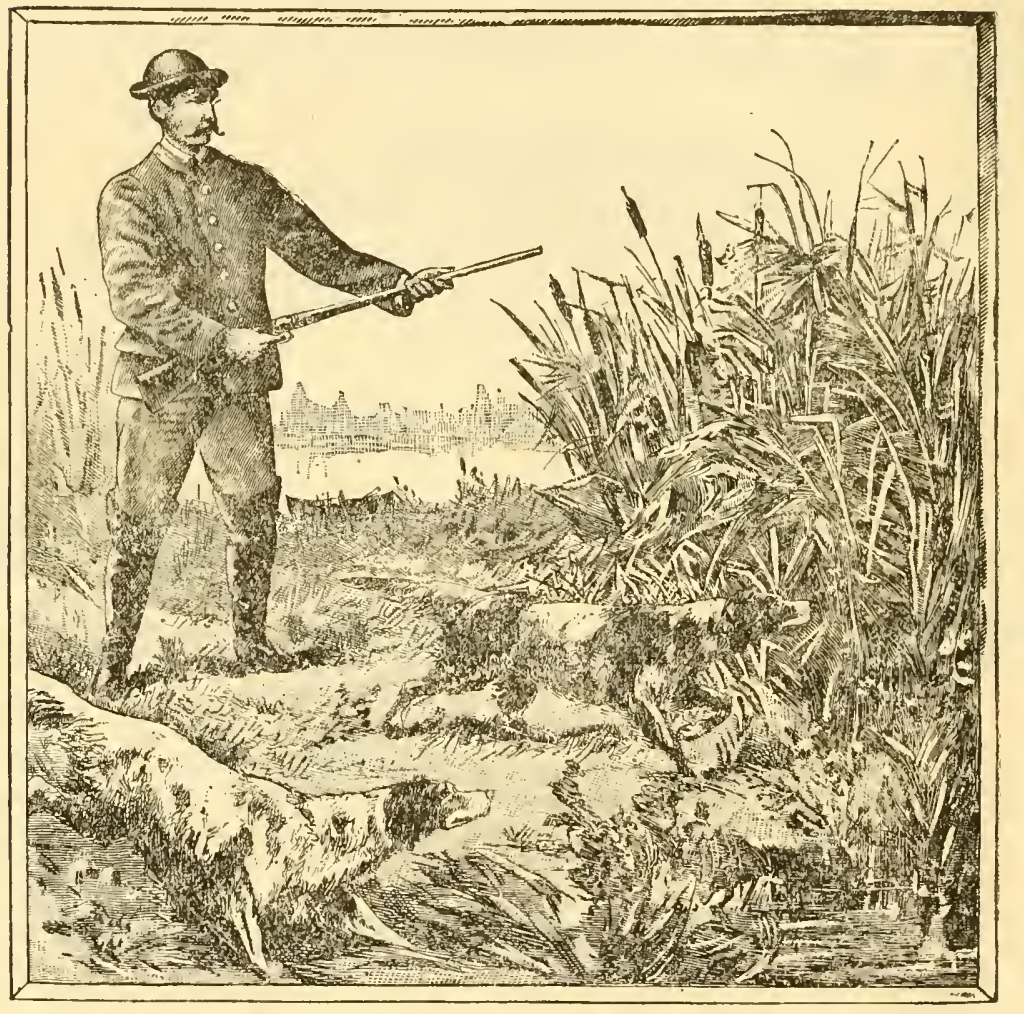

\section{SPORTSIENSS SUPPLIES OF EVERY DESCRIPTION.}

Camping Goods, Rubber Goods, Sportsmen's Clothing, Boots and Shoes, and Ammunition of all kinds.

178 BROADWAY, NEW YORK CITY. 


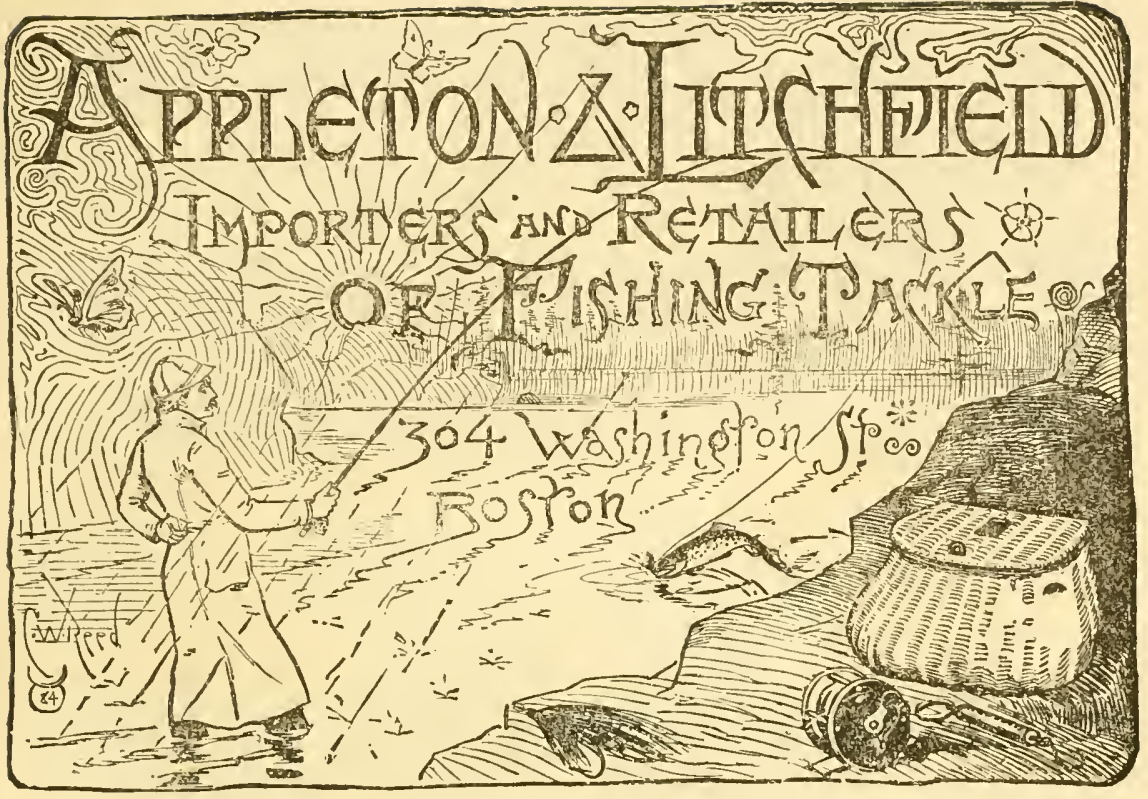

\section{SPECIAL TO ANGLERS.}

THE AMERICAN ANGLER.-A weekly journal devoted solely to fish, fishing and fish culture. is published on Saturday of each week. Subscription \$3.00 a year. Ten cents per copy.

l'ORTRAITS OF FISIIF. - Printed on tinted Bristol boards $7 \mathrm{x}$ I $\mathrm{I}$ inches. They are sixty in number; twenty-three are engravings of those killed in fresh water and thirty-seven of the salt water species The fresh water series, postage paid, $\$ 2.00$; salt water, $\$ 3.50$; whole series. $\$ 5.00$; single copies, Io vents. A handscme portfolio, Russian leather, $\$ 1.25$ post paid.

FISHES OF THE EAST FLORIDA COAST.-In pamphlet form, twelve engravings, post paid, 25 cents.

THE ANGLERS' SCORE BOOK.- With blanks and stubs for recording scores of fish; giving blanks for date, name of water, species of fish caught, number, weight of largest, total weight, size of largest, baits used, state of water, wind and weather Paper cover, Io cents; cloth, 25 cents post paid.

\section{The American Angler, 252 Broadway, New York.}




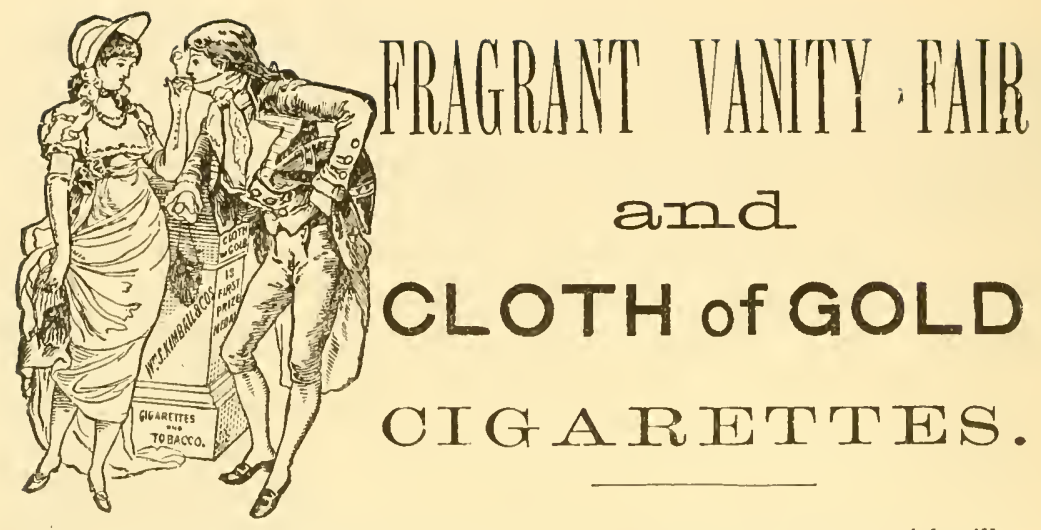

Our Cigarettes cannot be surpassed. If you do not use them, a trial will convince you that they have no equal. Two hundred millions sold in 1883 .

13 First Pı'ze Medals lA warded.

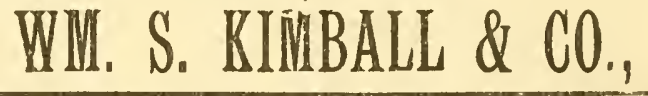

\section{PHOTOGRAPHY MADE EASY,}

By the New Dry Plate Process. No Stains, No Trouble.

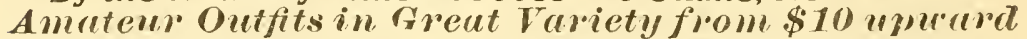
Send for illustrated catalogue or call and examine, as we take pleasure in showing our goods. We are sole proprietors of THE DETECTIVE CAMERA.

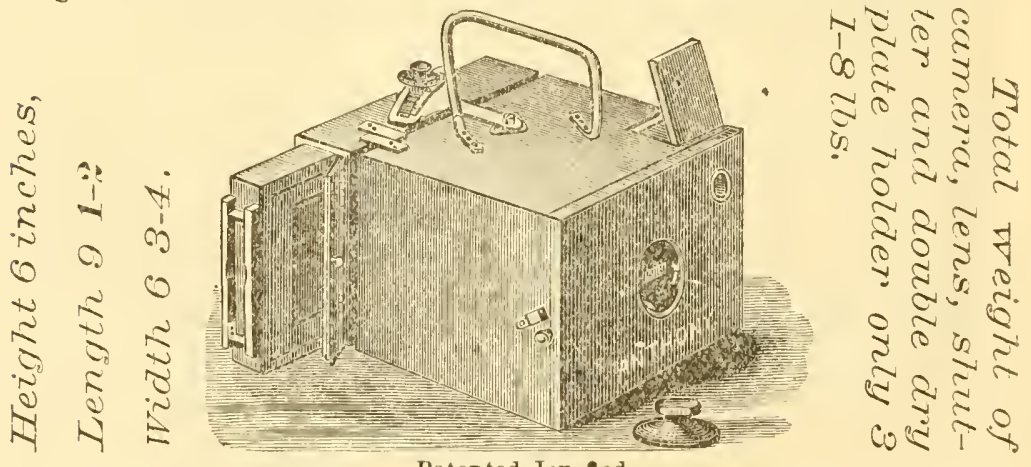

Patented Jan. ¿isd

The Lightest, Neatest and most Compart ( amera ever made. It is designed to be carried in the hand, and used without either tripod or focussing cloth. vescriptive Circular mailed on Application.

E. \& H. T. ANTHONY \& CO.,

Forty Ycars Established in this line of business 591 Broadway. New York, 
THE SUPERIORITY OF 'THE CELEBRA'TED

\title{
Hexagonal Split Bamboo Fishing Rods,
}

\author{
MINUFACIULEJ) $\mathrm{Bi}$
}

\section{B.F.MCHOLS, 153 Mik Street, Boston, Mass.,}

Is "vident trom the funt that the gentlemen who nse them are enthusiastic orer their good

Read the following letter:

South Kexington, October 18, 1883.

Dital SIr:-The special prize of $f 10$ for the collection of Salmon Rods distingnished more for their excellence than their milibers, has been awarded to yon by the Jury. Ir. Burdett Contts, who offererl the prize, asked me this morning to pleave convey to you his compliments and congratulations and was he $i+$ fontly pleasd that his prize has been awarded to an Americars and one wlzose rods aro so farombly and gemerally known as yours.

To B. F. Nrehols, Esq. Boston, Mass. YY. N. COX, U. S. Fish Commission.

[Copy letter received October 31.] Sencl for catalogne, with Massachnsetts Fish an: Game Laws-FREE. My Goods are sold in New York City by HAWKS \& OGILVY, 3no Broadway.

Split Bamboo Bass and Fly Rods, Flies and Fly Books, Aptificial Bait, Bait Boxes, Hooks, Etc.

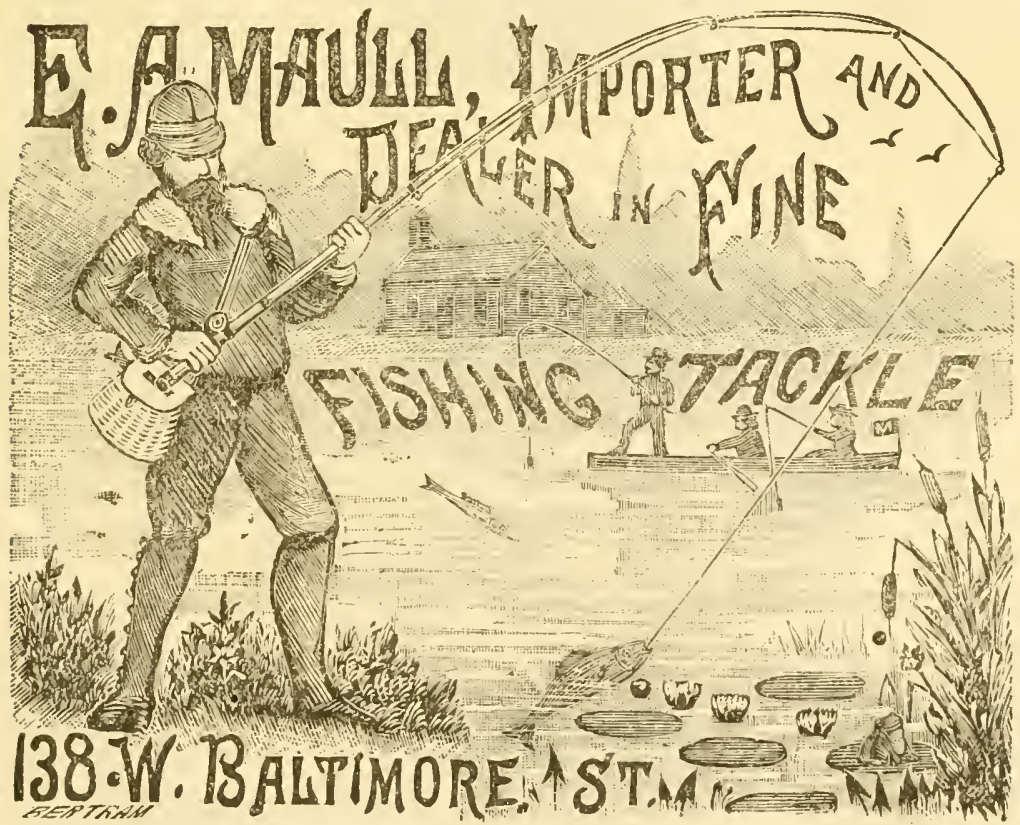

Water-proof Silk, Linen and Cotton Lines, Reels, Floata, Baskets., Sinkoru, Tenders 


\section{William.Wurfflein, \\ 208 NOrth Secend str st, Philatleipin!a, Pa.,}

IMPORTER OF

Fishing Tackle.

TROUT.

BASS AND SALIGOE

TACKLE,

For Brook, River, $L \cdots 0$

AND

Salt Wate:

FISHING.

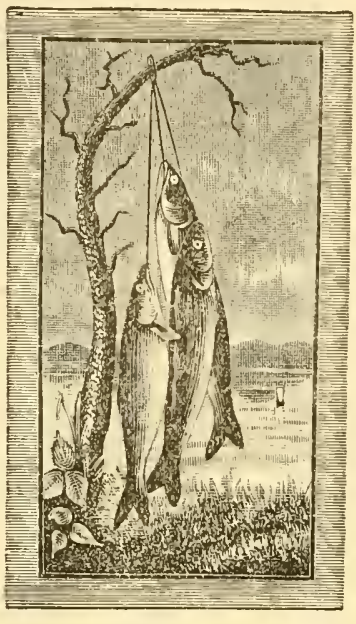

Rods,

Reels, Lines, Flies,

Hooks and Bait

OF EVERY DESCRIPTION,

of the Latest and Most

Tuproved Strles, IN

GREAT VARIETY,

\section{IT LOW PRICES.}

th Send for Priee List. Mention American ANGLer.

\section{PHILADELPHIA}

\section{FISHING T ACKLE HOUSE,}

MANUFACTURERS OF

Fishing Rods, Lines, Reels and Tackle of Every Description.

Outfits for Florida and Other Sea Fishing a Specialty.

Our No. 6,750 YisI Hooks are pronounced by "Al Fresco "THE BEST hook for" sea fishing made. We make a specialty of

\section{Hand-made Fishing Rods.}

Manufactured from the celebrated Bethabara Wood, they are stronger than the Split Bamboo, and as tomb and elastic as tempered steel.

An We are making an improvement on Gimp Snellv. Fvery Fisherman has experienced the difficulties attending the nse of Gimp, Linen or frut for this purpose. This Snood, being a combination of braided Linen and non-corrosive Flexible Wire, effectually prevents it from twisting around the line, and makes it the strongest and most durable Snell in the market. Price per doxen on best quality Hooks for Weakfish, 7o cents. Pickerel, 6o cents. Sea Bass, 50 cents. Fisbing Rods and Tackle can be sent by mail at 1e. per oz., and registerod, if desired, at 10 cents additional. 65-page Illustrated Price List of Fishing Tackle sent by mail for 10 cents in stamps.

A. B. SHIPLEY \& SON, 503 Commerce Street, 





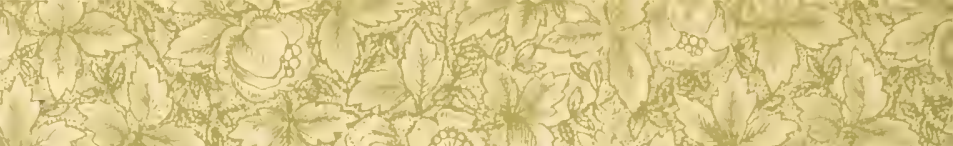

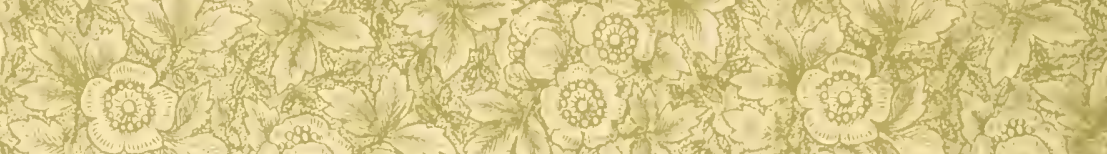
1 (1) 1 (1)

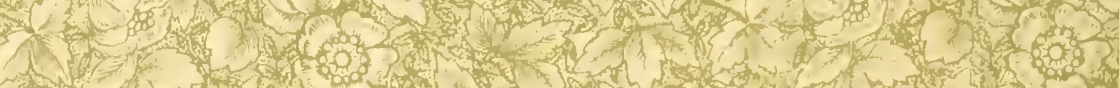

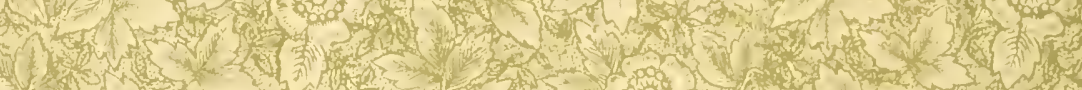

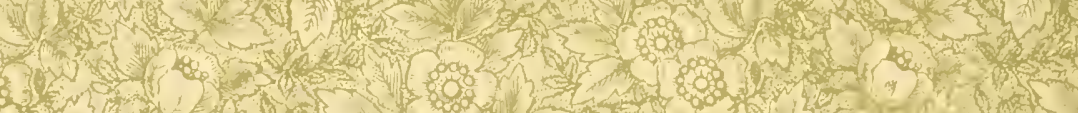
an? s.

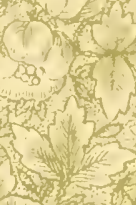
1.

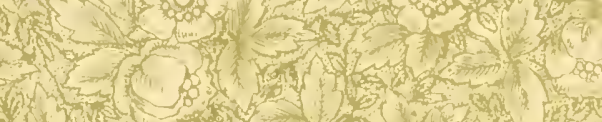
$\int^{2} 0^{2}$. 250

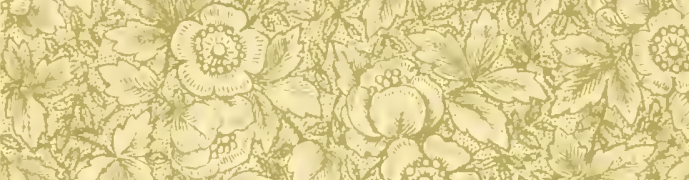
2. 18 Ans 


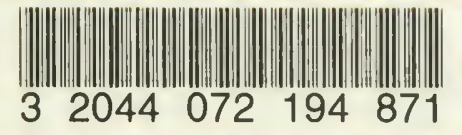

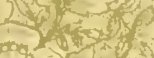

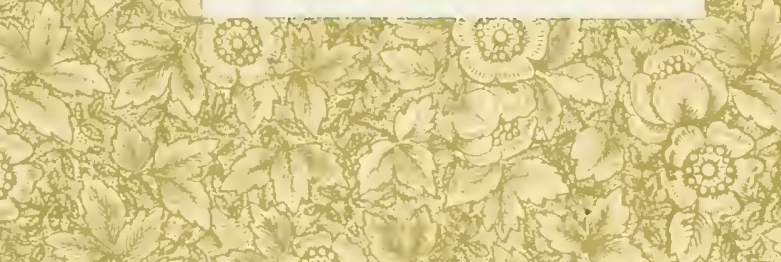




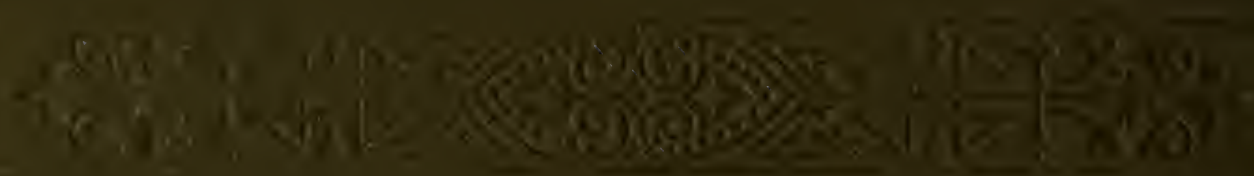
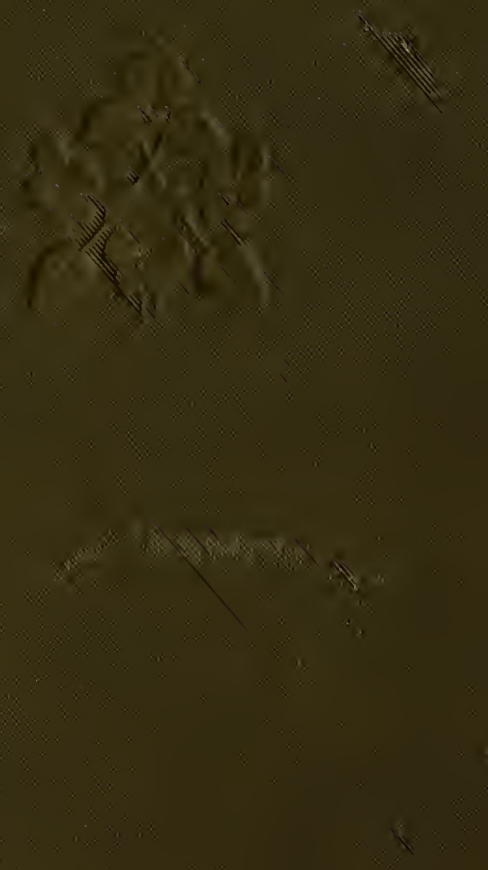

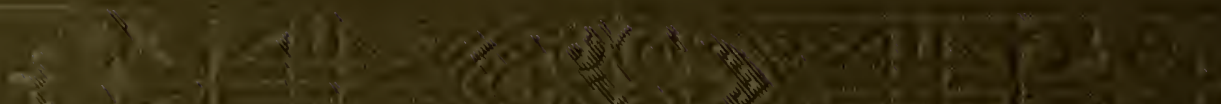

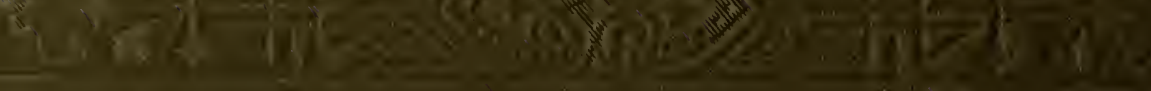

